UNIVERSIDADE DE SÃO PAULO

FACULDADE DE ZOOTECNIA E ENGENHARIA DE ALIMENTOS

ISABELA RODRIGUES DOS SANTOS

\title{
IRRADIAÇÃO E REDUÇÃO DE SÓDIO EM SALSICHA: SEGURANÇA, SAUDABILIDADE E PERCEPÇÃO DO CONSUMIDOR
}




\title{
IRRADIAÇÃO E REDUÇÃO DE SÓDIO EM SALSICHA: SEGURANÇA, SAUDABILIDADE E PERCEPÇÃO DO CONSUMIDOR
}

\author{
VERSÃO CORRIGIDA
}

Tese apresentada à Faculdade de Zootecnia e Engenharia de Alimentos da Universidade de São Paulo, como parte dos requisitos para defesa de doutorado do Programa de Pós-Graduação em Engenharia de Alimentos.

Área de Concentração: Ciências da Engenharia de Alimentos

Orientador: Prof. Dr. Marco Antonio Trindade

Pirassununga, 
Ficha catalográfica elaborada pelo

Serviço de Biblioteca e Informação, FZEA/USP, com os dados fornecidos pelo(a) autor(a)

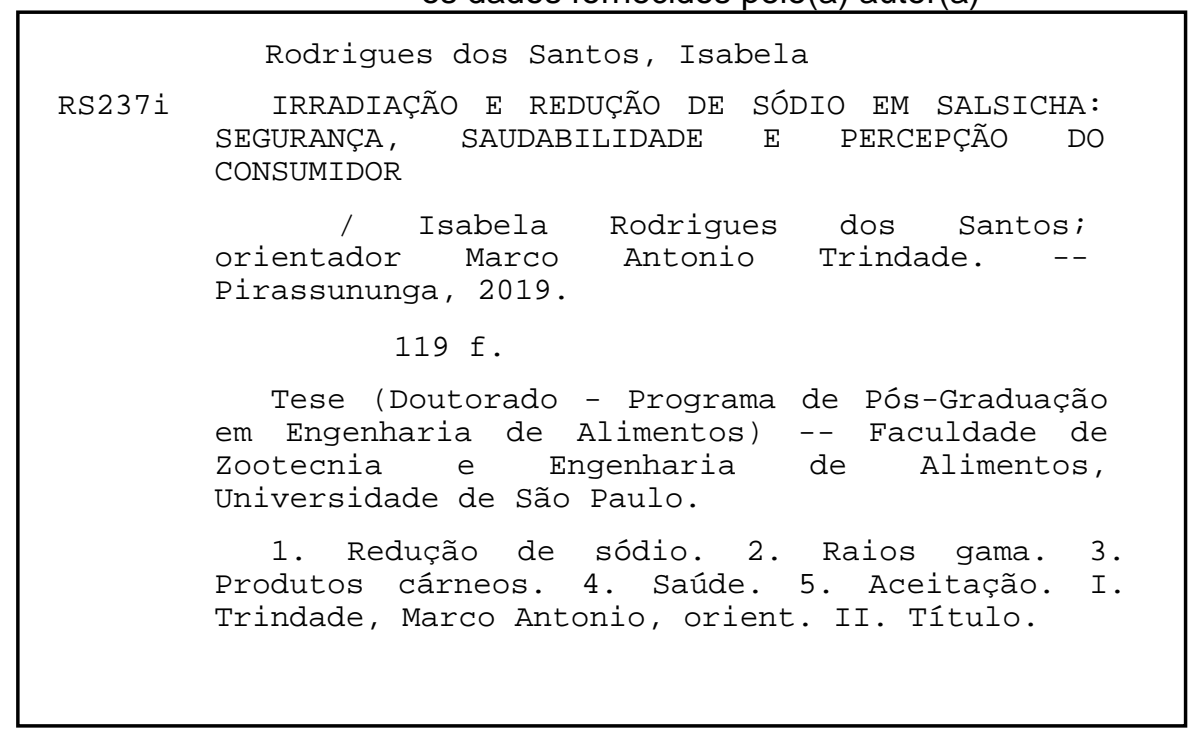

Permitida a cópia total ou parcial deste documento, desde que citada a fonte - o autor 


\title{
IRRADIAÇÃO E REDUÇÃO DE SÓDIO EM SALSICHA: SEGURANÇA, SAUDABILIDADE E PERCEPÇÃO DO CONSUMIDOR
}

\author{
Tese apresentada à Faculdade de Zootecnia e Engenharia \\ de Alimentos da Universidade de São Paulo, como parte \\ dos requisitos para defesa de doutorado do Programa de \\ Pós-Graduação em Engenharia de Alimentos.
}

Trabalho aprovado em 5 de maio de 2019.

Banca Examinadora:

Dra. Maria Begoña Penea Doblado

Centro de Investigación y Tecnología Agroalimentaria - CITA/ Zaragoza - Espanha

Profa. Dra. Andrea Carla da Silva Barreto

Universidade Estadual Paulista - UNESP

Profa. Dra. Cynthia Ditchfield

Faculdade de Zootecnia e Engenharia de Alimentos - Universidade de São Paulo/ FZEA-USP

Profa. Dra. Andrezza Maria Fernandes

Faculdade de Zootecnia e Engenharia de Alimentos - Universidade de São Paulo/ FZEA-USP

Profa. Dra. Judite das Graças Lapa Guimarães

Faculdade de Zootecnia e Engenharia de Alimentos - Universidade de São Paulo/ FZEA-USP 
Dedico este trabalho aos meus queridos pais, Raimundo e Lourdes, e ao meu irmão, Bruno. 


\section{Agradecimentos}

Agradeço a Deus, por ter me guiado pelo melhor caminho;

Aos meus amados pais, Raimundo e Lourdes, que me deram todas as ferramentas para enfrentar qualquer situação;

Ao meu irmão, Bruno, que me ajudou em várias etapas e me estimulou nos dias de desanimo;

À minha vó, Joana, pelo zelo e torcida;

À toda a minha família, pelo suporte e carinho;

Ao meu orientador Marco Antonio, por todos os ensinamentos;

Aos meus colegas do laboratório Larissa, Yana, Manoela, Paulo, Juliana Baldin, Julliane Carvalho, Allan e Paulo, pelo apoio, amizade, e pelas várias risadas;

Aos queridos estagiários: Aline Baldini, Letícia Gonçalves, Carlos Antonio e Fernanda Hajj sem os quais tudo teria sido mais difícil;

A todos os técnicos do ZEA, em especial o Alan, pela disponibilidade em ajudar,

Às minhas queridas amigas Nayla Souki, Letícia Ferreira por fazerem da nossa casa um lar, cheio de conforto e amizade;

À Fundação de Amparo á Pesquisa do Estado de São Paulo, pelo suporte financeiro (Auxílio à Pesquisa: 2015/12429-7),

À Coordenação de Aperfeiçoamento de Pessoal de Nível Superior - (CAPES) Brazil pela bolsa de estudos, Código 001. 
"A mente que se abre a uma nova ideia jamais voltará ao seu tamanho original."

Albert Einstein 


\section{RESUMO GERAL}

O alto consumo de sódio e gordura está relacionado com o desenvolvimento de diversas doenças como hipertensão e doenças coronarianas, o que leva à necessidade de reduzir a adição destes componentes em alimentos, reduzindo assim o seu consumo. Este projeto foi realizado em três etapas (capítulos), com o objetivo de entender: 1- o impacto da redução de sódio e gordura na produção e aceitação sensorial de salsicha; 2 - a influência da irradiação, como método de conservação, no crescimento microbiano e nas caraterísticas sensoriais de salsichas reduzidas em sódio e gordura; e 3 - como os consumidores de salsicha percebem a utilização de radiação nestes produtos. Para alcançar este objetivo, a primeira etapa do projeto foi realizada com a finalidade de determinar a menor concentração de sal $(\mathrm{NaCl})$ que pode ser utilizada na produção de salsicha já reduzida em gordura trazendo o menor impacto sensorial e de processo (textura, sabor, estrutura, estabilidade de emulsão). Para isso foram avaliadas formulações com $1 \mathrm{~g} / 100 \mathrm{~g}$ de $\mathrm{NaCl}(\mathrm{F} 1), 1,25 \mathrm{~g} / 100 \mathrm{~g}(\mathrm{~F} 1.25), 1,50$ g/100g (F1.50), 1,75 g/100g (F1.75) e 2 g/100g (F2- controle). Após a obtenção de uma formulação ideal na Etapa 1, a segunda etapa do projeto foi conduzida, aplicando-se três doses de radiação em salsichas com esta formulação. As doses foram zero (I0), 1,5 kGy (I1.5), 3,0 kGy (I3.0) e 4,5 kGy (I4.5). Foram avaliadas também salsichas sem redução de sódio e sem irradiar como formulação controle (F2). Os impactos da irradiação na oxidação lipídica, cor objetiva, valor de $\mathrm{pH}$, textura, crescimento microbiano e na aceitação sensorial foram avaliados durante 60 dias de estocagem refrigerada $\left(4{ }^{\circ} \mathrm{C}\right)$. Finalmente, na terceira etapa a Food Neophobia Technology Scale (FTNS) e o Focus Group foram conduzidos para entender a percepção do consumidor sobre a irradiação de alimentos. $\mathrm{O}$ teste Check-all-thatapply também foi aplicado para caracterizar salsichas reduzidas em sódio e irradiadas. Os resultados da etapa 1 demostraram que formulações com $1.25 \mathrm{~g} / 100 \mathrm{~g}$ de $\mathrm{NaCl}$ alcançaram aceitação sensorial e tiveram impacto tecnológico em nível aceitável, demonstrando que é 
possível a redução de até $27,18 \%$ de sódio em salsichas reduzidas em gordura. Esta foi a formulação escolhida para as etapas seguintes. A utilização de radiação foi bastante eficaz no controle do desenvolvimento microbiano. A menor dose utilizada (1,5 kGy) foi suficiente para controlar o desenvolvimento de bactérias durante 60 dias de armazenamento refrigerado $\left(4 \quad{ }^{\circ} \mathrm{C}\right)$. Todas as amostras irradiadas apresentaram aceitação (nota maior que 5) pelos consumidores e oxidação lipídica abaixo do limite que causaria percepção de ranço. Os estudos com consumidor, realizados na Etapa 3, demonstram que os receios relacionados ao consumo de alimentos irradiados estão fortemente arraigados nos consumidores. A ideia de que o fornecimento de informações sobre a tecnologia de irradiação poderia diminuir a neofobia não foi comprovada na análise da FTNS, embora os estudantes, que tiveram maior nível de informação, tenham se mostrado mais receptivos a esta tecnologia nos estudo com Focus Groups. De forma geral, jovens foram mais receptivos que os adultos. No teste CATA, salsichas irradiadas foram caracterizadas de forma similar às não irradiadas, entretanto características diferentes foram atribuídas a salsichas com e sem redução de sódio. Concluiuse que a irradiação é uma alternativa efetiva para controle microbiológico de salsicha com redução de sódio, entretanto a aceitação pelos consumidores compromete sua utilização. Campanhas mais efetivas de conscientização e informação devem ser realizadas para que a tecnologia seja aceita.

Palavras-chave: Redução de sódio, raios gama, produtos cárneos, saúde, aceitação. 


\begin{abstract}
The high consumption of sodium and fat is related to the development of several diseases such as hypertension and coronary heart disease, which leads to the need to reduce the addition of these components in food, thus reducing their consumption. This project was carried out in three stages (chapters), with the objective of understanding: 1- the impact of sodium and fat reduction on the production and sensorial acceptance of sausage; 2 - the influence of irradiation, as a conservation method, on microbial growth and the sensorial characteristics of sausages reduced in sodium and fat; and 3 - how sausage consumers perceive the use of radiation in these products. In order to reach this objective, the first stage of the project was carried out with the purpose of determining the lowest salt concentration $(\mathrm{NaCl})$ that can be used in the production of sausage already reduced in fat, with the lowest sensory and process impact (texture, structure, emulsion stability). For this purpose, formulations containing $1 \mathrm{~g} / 100 \mathrm{~g}$ of $\mathrm{NaCl}(\mathrm{F} 1), 1.25 \mathrm{~g} / 100 \mathrm{~g}(\mathrm{~F} 1.25), 1.50 \mathrm{~g} / 100 \mathrm{~g}$ (F1.50), $1.75 \mathrm{~g} / 100 \mathrm{~g}(\mathrm{~F} 1.75)$ and $2 \mathrm{~g} / 100 \mathrm{~g}$ (F2-control). After obtaining an ideal formulation in Step 1, the second stage of the design was conducted by applying three doses of radiation to sausages with this formulation. The doses were zero (I0), $1.5 \mathrm{kGy}$ (I1.5), 3.0 kGy (I3.0) and 4.5 kGy (I4.5). Sausages were also evaluated without sodium reduction and without irradiation as control formulation (F2). The effects of irradiation on lipid oxidation, objective color, $\mathrm{pH}$ value, texture, microbial growth and sensorial acceptance were evaluated during 60 days of refrigerated storage $\left(4{ }^{\circ} \mathrm{C}\right)$. Finally, in the third stage the Food Neophobia Technology Scale (FTNS) and the Focus Group were conducted to understand the consumer's perception of food irradiation. The Check-all-that-apply test was also applied to characterize reduced sodium and irradiated sausages. The results of step 1 demonstrated that formulations with $1.25 \mathrm{~g} / 100 \mathrm{~g}$ of $\mathrm{NaCl}$ reached sensory acceptance and had technological impact at an acceptable level, demonstrating that it is possible to reduce sodium up to $27.18 \%$ in sausages
\end{abstract}


reduced in fat. This was the formulation chosen for the following steps. The use of radiation was quite effective in controlling microbial development. The lowest dose (1.5 kGy) was sufficient to control the development of bacteria during 60 days of refrigerated storage. All irradiated samples showed acceptance (score higher than 5) by consumers and lipid oxidation below the limit that would cause rancidity perception. The consumer studies conducted in Step 3 demonstrate that fears related to the consumption of irradiated foods are strongly rooted in consumers. The idea that the provision of information on irradiation technology could reduce neophobia has not been proven in the FTNS analysis, although the students with higher levels of information have been more receptive to this technology in the Focus Groups studies. Overall, young people were more receptive than adults. In the CATA test, irradiated sausages were characterized in a manner similar to those not irradiated, however different characteristics were attributed to sausages with and without sodium reduction. It was concluded that irradiation is an effective alternative for the microbiological control of sausage with sodium reduction, however the acceptance by the consumers compromises its use. More effective awareness and information campaigns must be carried out in order for the technology to be accepted.

Key words: Reduction of sodium, gamma rays, meat products, health, acceptance. 


\section{LISTA DE FIGURAS}

\section{CAPÍTULO I}

Figura I. 1- Imagens de microscopia eletronica de varredura para salsichas com concentrações variáveis de $\mathrm{NaCl}$ na aproximações 50x (A), 100x (B) e 500x (C).

\section{CAPÍTULO II}

Figura II. 1- Medidas de cor do sistema CIE Lab para salsicha com redução de sódio irradiadas em doses de 1,5, 3,0 e 4,5 KGy e para salsichas não irradiadas com redução de sódio (F0) e sem redução de sódio (F2) por 75 dias de armazenamento refrigerado $\left(4{ }^{\circ} \mathrm{C}\right)$

Figura II. 2- Medidas de dureza e mastigabilidade para salsicha com redução de sódio irradiadas com doses de 1,5, 3,0 e 4,5 KGy e salsichas não irradiadas com redução de sódio (F0) e sem redução de sódio (F2) durante 75 dias de armazenamento refrigerado $\left(4{ }^{\circ} \mathrm{C}\right) .79$

\section{CAPÍTULO III}

Figura III. 1- Símbolo radura, que identifica alimentos irradiados, apresentado aos participantes do Focus Group. 96

Figura III. 2- Distribuição gráfica das salsichas com redução de em sódio e irradiadas em relação aos atributos sensoriais percebidos pelos consumidores no teste CATA .. 112 


\section{LISTA DE TABELAS}

\section{REVISÃO DE LITERATURA}

Tabela 1 - Exemplos de doses de radiação utilizada na preservação de alimentos.. 26

\section{CAPÍTULO I}

Tabela I. 1 - Composição centesimal e concentração de sódio (Na) nas formulações de salsicha com redução de sódio e gordura 52

Tabela I. 2 Médias das análises realizadas em formulações de salsicha com reduzido teor de gordura e sal $(\mathrm{NaCl})$ 54

Tabela I. 3- Aceitação sensorial e testes JAR para salsichas com teor reduzido de gordura e sal. 59

\section{CAPÍtULO II}

Tabela II. 1 Formulações utilizadas no preparo de salsicha com e sem redução de sódio 69

Tabela II. 2- Concentração de substâncias reativas ao ácido tiobarbitúrico (Tbars) e variação dos valores de $\mathrm{pH}$ durante 75 dias de armazenamento refrigerado para salsichas com 1,25 ou $2 \%$ de $\mathrm{NaCl}$ submetidas a diferentes doses de radiação 75

Tabela II. 3- Crescimento de bactérias lácticas e bactérias psicrotróficas anaeróbias durante 75 dias de armazenamento refrigerado de salsichas com 1,25 ou $2 \%$ de $\mathrm{NaCl}$ submetidas a diferentes doses de radiação 81

Tabela II. 4- Resultados do teste sensorial de aceitação de salsichas com 1,25 ou 2\% de $\mathrm{NaCl}$ submetidas a diferentes doses de radiação 83 


\section{CAPÍTULO III}

Tabela III. 1- Formulações de salsichas irradiadas e não-irradiadas (F2).

Tabela III. 2- Médias das pontuações atribuídas a cada item da FTNS por consumidores informados (I) e não informados (NI) sobre a tecnologia de irradiação. 101

Tabela III. 3 - Perfil dos participantes selecionados para compor os quatro grupos de discussão (Focus Group) 102

Tabela III. 4 - Atributos selecionados para compor a lista do teste CATA aplicado a salsichas com redução de sódio e irradiadas 110 


\section{SUMÁRIO}

1. INTRODUÇÃO GERAL ......................................................................................... 19

2. REVISÃO DE LITERATURA............................................................................22

2.1. Efeitos do consumo de sódio na saúde humana..............................................2 22

2.2. Importância do $\mathrm{NaCl}$ no processamento de alimentos cárneos ......................... 24

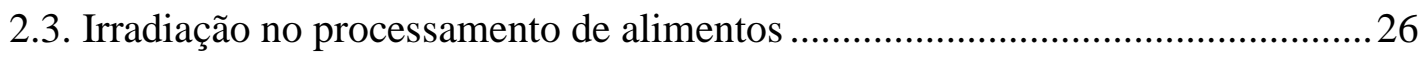

2.3.1. Utilização da radiação gama na produção de alimentos mais seguros .......28

2.3.2. Segurança microbiológica de produtos com reduzida concentração de sódio

2.4. A percepção do consumidor sobre tecnologias emergentes

2.5. Percepção do consumidor .

2.5.1. Neofobia Alimentar.

2.5.2. Focus group

2.5.3. Check-all-that-apply (CATA).

REFERÊNCIAS.

CAPÍtUlO I - ENTENDENDO A REDUÇÃO DE SAL EM SALSICHAS

COM REDUZIDA CONCENTRAÇÃO DE GORDURA: ESTRUTURA DA REDE, ESTABILIDADE DA EMULSÃO E ACEITAÇÃO DO CONSUMIDOR..........................44

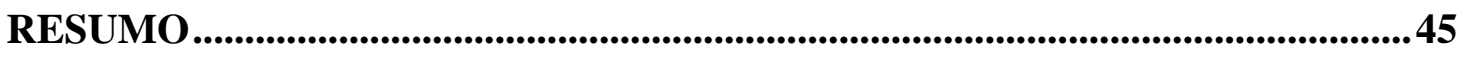

1. INTRODUÇÃ̂̃O

2. MATERIAIS E MÉTODOS ...................................................................................48 
2.2. Composição centesimal e concentração de sódio

2.3. Atividade de água (Aa)

2.4. Microscopia Eletrônica de Varredura (MEV)

2.5. Análise de perfil de textura (TPA).

2.6. Estabilidade da emulsão e porcentagem de gordura liberada 50

2.7. Valor de $\mathrm{pH}$. 50

2.8. Cor objetiva 50

2.9. Análise sensorial 51

2.10. Análise estatística 51

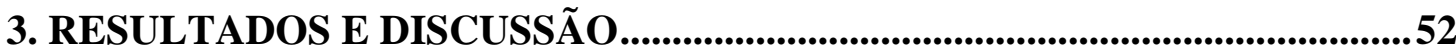

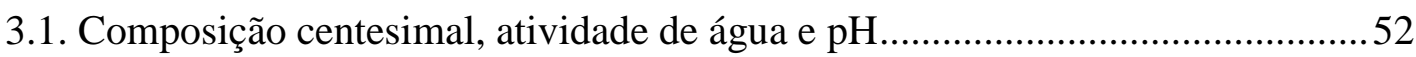

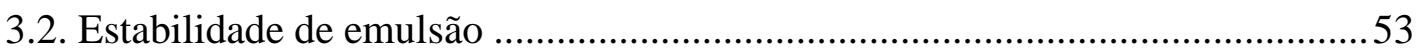

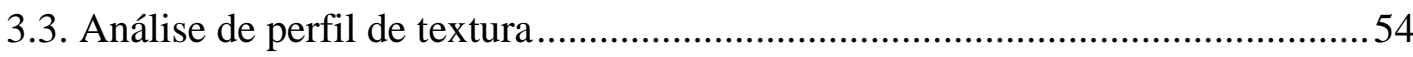

3.4. Microscopia Eletrônica de Varredura (MEV) …..............................................55

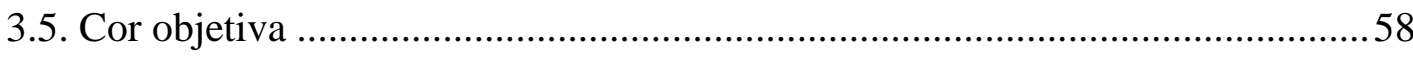

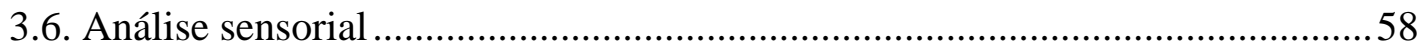

4. CONCLUSÃ

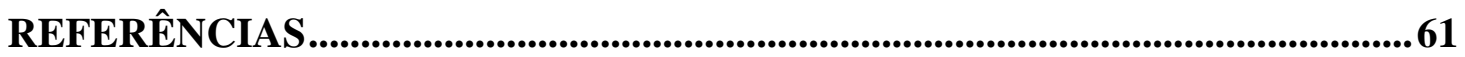

CAPÍTULO II - UTILIZAÇÃO DE RADIAÇÃO COM RAIOS GAMA PARA AUMENTAR A VIDA ÚTIL DE SALSICHA COM REDUÇÃO DE SAL 64 
1. INTRODUÇÃ̂̃

2. MATERIAIS E MÉTODOS .......................................................................................68

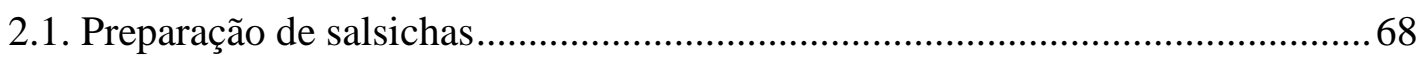

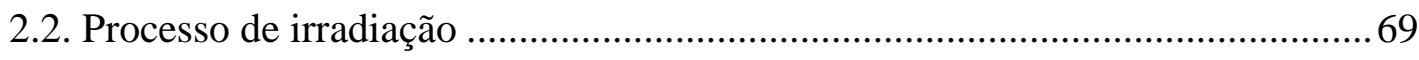

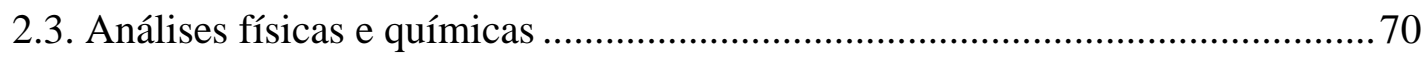

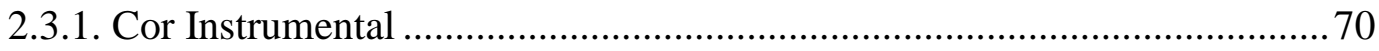

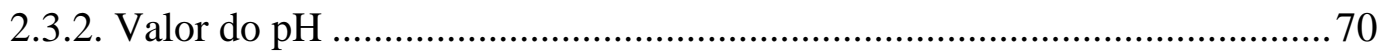

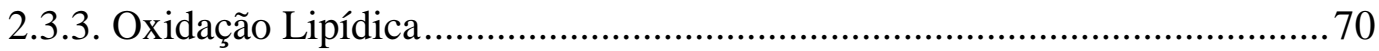

2.3.4. Análise de perfil de textura (TPA) ....................................................... 71

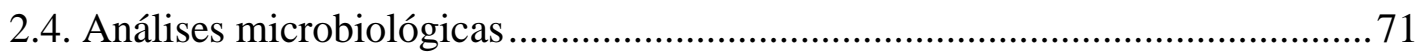

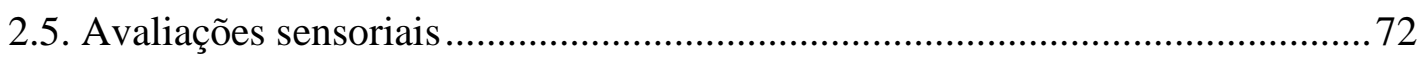

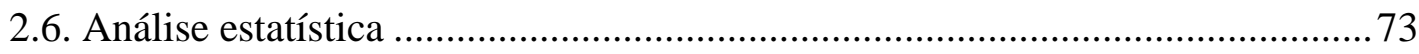

3. RESULTADOS E DISCUSSÃO ...................................................................73

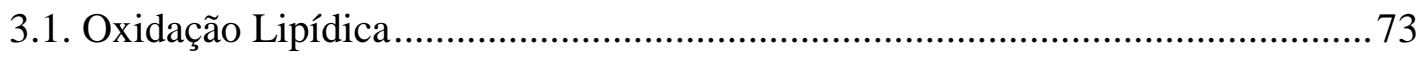

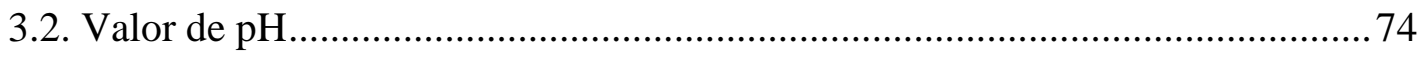

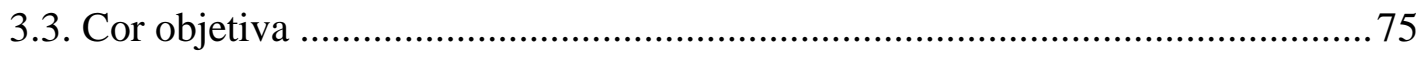

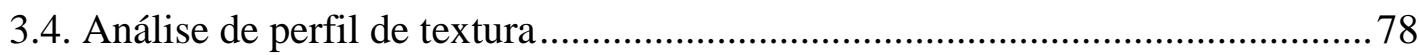

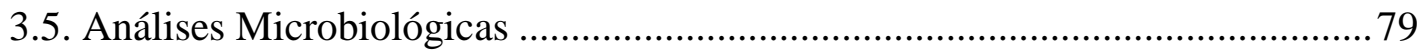

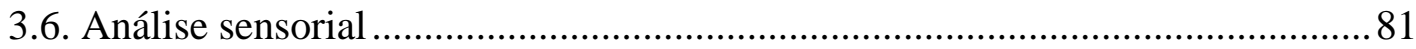

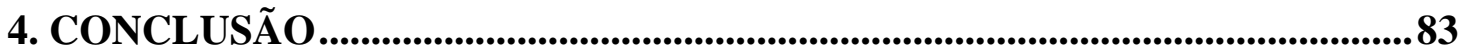


REFERÊECIAS.

\section{CAPÍTULO III -PERCEPÇÃO DO CONSUMIDOR SOBRE O USO DA RADIAÇÃO PARA PRODUZIR PRODUTOS CÁRNEOS MAIS SAUDÁVEIS ..........88}

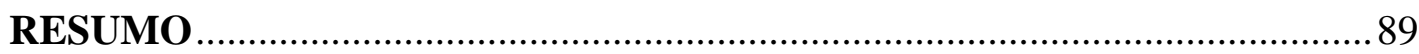

1. INTRODUÇÃ

2. MATERIAIS E MÉTODOS ...............................................................................94

2.1. Food Neophobia Technology Scale - FTNS ................................................ 94

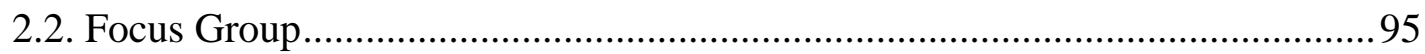

2.2.1. Seleção de participantes e grupos ......................................................... 95

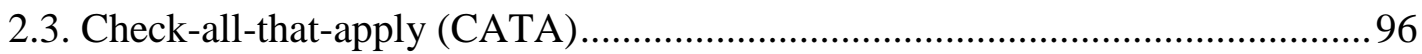

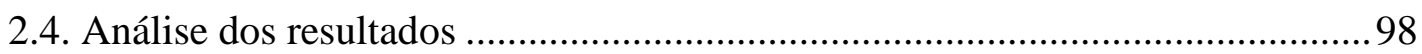

3. RESULTADOS E DISCUSSÃO

3.1. Food Neophobia Technology Scale …....................................................... 99

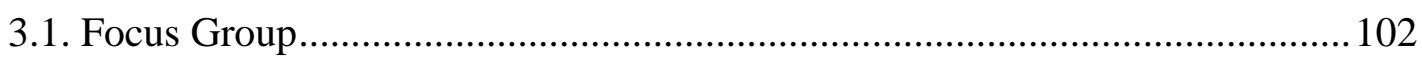

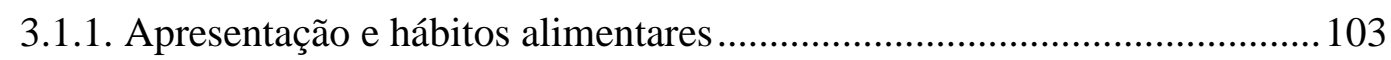

3.1.2. Produtos cárneos: saudáveis ou não saudáveis? ....................................... 103

3.1.3. O que pode ser feito para tornar os produtos cárneos mais saudáveis?.... 104

3.1.4. O que é irradiação de alimentos? Qual seria o propósito da irradiação de alimentos?...... 104

3.1.5. Quais aspectos o impediriam ou o encorajariam a consumir alimentos irradiados? 
3.1.6. Você costuma ler o rótulo dos alimentos que consome? Qual símbolo identifica um alimento irradiado? O radura é um símbolo que representa bem um alimento irradiado? 106

3.2. Check-all-that-apply (CATA)..... 109

4. CONCLUSÃO .113

REFERENCIAS. 114 CONCLUSÃO GERAL.. 117 


\section{INTRODUÇÃO GERAL}

Reduções de sódio e gordura em produtos cárneos são grandes preocupações para consumidores e indústrias. O sódio está envolvido no desenvolvimento de doenças como hipertensão arterial e infarto, enquanto que o conteúdo de gordura rico em ácidos graxos saturados e colesterol podem aumentar a incidência de doenças coronarianas, obesidade e certos tipos de câncer (FELISBERTO et al., 2015).

A principal fonte de sódio em produtos cárneos é o $\mathrm{NaCl}$. No caso de produtos cárneos emulsionados, devido às funções do $\mathrm{NaCl}$, a redução de sódio é um tópico que ainda precisa ser explorado. A redução de gordura também é uma tendência contínua, e enfrenta desafios como alterações no sabor e textura dos produtos acabados (YOUSSEF; BARBUT, 2011). Segundo Totosaus e Pérez-Chabela (2009) a redução simultânea de gordura e $\mathrm{NaCl}$ em produtos cárneos emulsionados é um desafio tecnológico, pois quando ambos são reduzidos a água usada para repor a gordura provoca uma diminuição da força iônica para $<0,4$. Isso afeta vários parâmetros como percepção de gosto salgado, sabor de forma geral, textura, capacidade de retenção de água e o efeito conservante.

Visando melhorar ou substituir tecnologias de processamento convencionais, proporcionando produtos de maior qualidade para o consumidor, uma série de tecnologias inovadoras, também conhecidas como "emergentes" ou "novas" têm sido investigadas e, em alguns casos, comercializadas (DE BARCELLOS et al., 2010; KNOERZER, 2016). No entanto, enquanto os cientistas recebem com entusiasmo tais avanços tecnológicos, os consumidores têm mantido uma postura mais conservadora e nem sempre percebem prontamente os benefícios de novos métodos de processamento (NIELSEN et., 2009; OLSEN, GRUNERT, \& SONNE, 2010; PERREA; GRUNERT; KRYSTALLIS, 2015). 
Strijbos et al. (2016), afirmam que a fim de evitar o ceticismo dos consumidores sobre o uso das tecnologias não convencionais, pode-se evidenciar os ganhos relacionados à saúde, oferecendo ao consumidor uma visualização clara da relação entre o produto e os benefícios reivindicados.

Neste estudo, a irradiação com raios gama é proposta como ferramenta para garantir a segurança microbiológica de salsicha com concentrações de sal $(\mathrm{NaCl})$ e gordura reduzidas. Segundo Syarifuddin et al. (2016), embora muitas tecnologias venham sendo estudadas a fim de adequar os produtos às recomendações diárias de ingestão de sal, o maior desafio ainda é desenvolver um produto que seja aceito pelo consumidor. Ruusunem et al. (2003) esclarecem que um produto cárneo aceitável com baixo teor de sódio, em função da redução do teor de $\mathrm{NaCl}$ adicionado, pode ser obtido aumentando-se a quantidade de proteína cárnea e diminuindo-se a quantidade de água. Entretanto, o $\mathrm{NaCl}$ apresenta função bacteriostática e a redução da sua concentração no alimento pode levar à maior proliferação microbiana e, consequentemente, menor segurança microbiológica e menor vida de prateleira do produto.

Além dos efeitos bacteriostático e flavorizante, o cloreto de sódio possui diversas funções tecnológicas, como a de ativar proteínas, aumentando sua capacidade de hidratação e ligação com água, melhorar a estabilidade de géis, reduzir a atividade de água do produto e possibilitar a solubilização de proteínas miofibrilares (LOBO, 2016; YOTSUYANAGI, 2016). Ruusunen et al. (2005) relatam ainda que a redução do sal, além de diminuir a percepção do gosto salgado, enfraquece de forma geral o sabor dos produtos cárneos.

A gordura está envolvida em vários atributos de qualidade em produtos cárneos, como textura, sabor, propriedades tecnológicas, maciez, suculência, aparência e prazo de validade (FURLÁN; PADILLA; CAMPDERRÓS, 2014; SOUSA et al, 2017; YOUSSEF; BARBUT, 2011). Segundo Ding et al (2018), produtos cárneos com baixo teor de gordura apresentam 
textura mais dura, menor suculência e pior sabor. Consequentemente, esses produtos podem ter sua aceitabilidade afetada negativamente (MORA-GALLEGO et al, 2014).

São hipóteses deste trabalho:

1- Existe uma concentração de $\mathrm{NaCl}$ mínima que pode ser utilizada em produtos cárneos emulsionados e com teor de gordura reduzido de forma a conservar as características do produto próximas ao tradicional, mas com menores riscos à saúde pela menor ingestão de sódio e gordura saturada;

2- Uma estratégia para controlar o crescimento microbiano pode ser necessária em salsichas reduzidas em sódio e gordura;

3- $\quad$ A utilização de radiação como forma de conservação de salsicha com redução de sódio e gordura pode não ser aceita pelo consumidor deste produto.

Considerando-se esses aspectos foram objetivos deste estudo:

1- Avaliar a como redução de $\mathrm{NaCl}$ influencia os parâmetros tecnológicos e sensoriais da salsicha reduzida em gordura;

2- Analisar a eficiência da radiação gama como forma de garantir a segurança microbiológica de salsicha reduzida em sódio;

3- $\quad$ Estudar os efeitos da irradiação e da redução de $\mathrm{NaCl}$ nos atributos físico-químicos e sensoriais da salsicha;

4 - Entender a percepção do consumidor em relação a produtos cárneos irradiados. 


\section{REVISÃO DE LITERATURA}

\subsection{Efeitos do consumo de sódio na saúde humana}

O sódio é o principal cátion presente no fluido extracelular, e ele é responsável por diversas funções vitais na fisiologia dos mamíferos, como a manutenção do volume de fluidos extracelulares, a transmissão de impulsos nervosos e o balanço ácido-base (WHO, 2014a). Apesar de suas diversas funções, a necessidade de sódio pelo corpo humano é da ordem de miligramas; o requerimento mínimo diário para um adulto varia entre 300 a 500 mg (NATIONAL RESEARCH COUNCIL, 1989). Entretanto, de acordo com a WHO (2014b) a maioria da população mundial consome sódio em excesso. A população americana, por exemplo, consome em média $3400 \mathrm{mg}$ de sódio por dia por pessoa (BOBOWSKI; RENDAHL; VICKERS, 2015). A população brasileira consome em média 4460 mg de sódio por pessoa por dia (Associação Brasileira da Indústria de Alimentos - ABIA, 2013).

Com base nesses valores, o United States Department of Agriculture (USDA, 2010) recomendou a redução da ingestão de sódio para 2300 mg por dia para o cidadão americano. E, no Brasil, o Ministério da Saúde (2006) instruiu a ingestão máxima de 2400 mg por pessoa por dia.

A preocupação das autoridades em promover a redução da ingestão de sódio deriva da relação entre o elevado consumo dessa substância e o aumento do número de doenças não transmissíveis (DNT), entre as quais estão a hipertensão arterial, as doenças cardiovasculares e o acidente vascular cerebral (AVC) (BIBBINS-DOMINGO et al., 2010; WHO, 2003). As doenças não transmissíveis são a principal causa de morte no mundo, elas são responsáveis por aproximadamente $60 \%$ dos óbitos, sendo que deste total $80 \%$ ocorrem em países de renda baixa ou média (WHO, 2010). Em contrapartida, a World Health Organization (WHO) 
(2014a) evidencia que a redução no consumo de sódio reduziu significativamente a pressão arterial sistólica e diastólica em adultos e crianças.

Segundo dados da Associação Brasileira da Indústria de Alimentos (ABIA, 2013), a maior parte do consumo de sódio pelo brasileiro ocorre pela ingestão do sal de cozinha (cloreto de sódio) adicionado nas refeições preparadas em casa, o que representa 59,7\% do total de sódio ingerido. Em segundo lugar encontram-se os alimentos industrializados, que colaboram com 13,8 \% da ingestão de sódio. Essa diferença fica evidente ao compararmos a ingestão de sódio nas regiões Norte e Sudeste do país. Na região Norte registra-se o maior consumo de sódio do Brasil, e também a menor participação da indústria. No Sudeste registrase a maior participação industrial na ingestão de sal, mas este valor não atinge $30 \%$ do total ingerido. Diferentemente, de 75 a $80 \%$ do cloreto de sódio consumido pela população em países desenvolvidos são provenientes de restaurantes e alimentos processados (REEVE; MAGNUSSON, 2015).

Horita et al. (2014) relatam que os produtos cárneos são responsáveis por 20 a 30\% do total diário de ingestão de $\mathrm{NaCl}$. Além da contribuição para o total de sódio $(\mathrm{Na})$ pelo $\mathrm{NaCl}, \mathrm{o}$ teor de sódio em produtos cárneos é de 10-20\% mais elevado devido a fontes adicionais de $\mathrm{Na}$ tais como fosfatos de sódio $(0,5 \mathrm{~g} / 100 \mathrm{~g}))$ e nitrito de sódio $(0,015 \mathrm{~g} / 100 \mathrm{~g})$ (ANVISA, 1998; TAMM et al., 2016). Desta forma, a fim de reduzir o consumo de sal pela população é necessário que haja envolvimento tanto das indústrias, como dos serviços de alimentação e da população em geral.

Avaliando-se o histórico de alto consumo de $\mathrm{NaCl}$ pelos consumidores brasileiros, um dos grandes desafios da indústria é encontrar aceitação por parte do consumidor para alimentos produzidos com teor de sódio reduzido ou baixo. 


\subsection{Importância do $\mathrm{NaCl}$ no processamento de alimentos cárneos}

Em produtos cárneos o papel do $\mathrm{NaCl}$ pode ser dividido em três categorias principais: conservação, processamento, e atributos sensoriais (MCGOUGH et al., 2012). De forma geral, o $\mathrm{NaCl}$ é utilizado em alimentos com a função de garantir a segurança microbiológica, pois ele atua na redução da atividade da água (Aa) e, consequentemente, da proliferação microbiana. Segundo Inguglia et al. (2017), a adição de íons de sódio ao meio causa o efluxo de água através da membrana semipermeável da bactéria, o que pode causar choque osmótico com consequente redução da proliferação bacteriana ou a morte da célula.

Outros efeitos que a presença do $\mathrm{NaCl}$ pode causar são: limitação da solubilidade do oxigênio, interferência na ação das enzimas celulares e indução do gasto de energia para excluir íons de sódio da célula. Todos estes efeitos podem reduzir a taxa de crescimento do microrganismo (INGUGLIA et al., 2017). De acordo com Aaslyng et al. (2014), uma redução na concentração de sal para valores inferiores a $1,7 \%$ em salsicha resultaria na diminuição da vida de útil do produto além de mudanças significativas nas propriedades sensoriais. $\mathrm{O} \mathrm{NaCl}$ também interage com as proteínas levando à solubilização das proteínas miofibrilares, inchamento da miosina e da actina e promoção da ligação entre proteínas (TAMM et al., 2016), o que é uma função essencial no processamento de produtos cárneos. Por isso, a adição de sal desempenha um papel decisivo na estrutura e no rendimento destes produtos (DOYLE; GLASS, 2010).

Além disso, o $\mathrm{NaCl}$ também atua como intensificador de sabor. McGough et al. (2012), afirmam que na busca pela redução do sódio é essencialmente importante estudar maneiras de manter o gosto salgado tradicionalmente associado com carnes processadas, ao mesmo tempo que se deve evitar a introdução de sabores não tradicionais, como os de sais substitutos, os quais são frequentemente rejeitados pelo consumidor. 
Todos estes aspectos apontam para o desafio tecnológico que é a redução do $\mathrm{NaCl}$ em produtos cárneos, de forma a manter a qualidade (sensorial, microbiológica, processo) dos produtos. Diversos pesquisadores assumiram este desafio abordando diferentes estratégias: McGough et al. (2012) demonstraram que é possível reduzir a concentração de sal adicionado em salsichas pela utilização de realçadores de sabor naturais. Os autores indicaram a redução de $\mathrm{NaCl}$ em $20 \%$ com o uso do realçador ou em $35 \%$ se o $\mathrm{KCl}$ for utilizado como substituto. As salsichas obtiveram boa aceitação sensorial, apesar de apresentarem textura menos firme e cor mais escura. Dos Santos et al. (2014) conseguiram reduzir $68 \%$ do $\mathrm{NaCl}$ em linguiça fermentada através da substituição por $\mathrm{KCl}(75 \%)$ e utilização de glutamato monossódico, inosinato dissódico, guanilato dissódico, lisina e taurina como realçadores de sabor. Consumidores perceberam diferenças na cor, sabor e aroma das amostras. A análise instrumental de textura também indicou redução da dureza, mastigabilidade e coesividade.

Puolanne, Ruusunen e Vainionpaa (2001), Omana, Plastow e Betti (2011), Grossi et al. (2012), Myers et al. (2013), Horita et al. (2014), e Lilic et al. (2015) são alguns dos pesquisadores que também têm explorado diversas abordagens a fim de contornar os efeitos adversos da redução do cloreto de sódio em alimentos. Dentre os estudos realizados por eles podem-se citar inovações no uso de ingredientes, como a fibra de cenoura, amido de batata e $\beta$-glucana, a utilização de sais substitutos, como os fosfatos e o cloreto de potássio e o processamento com tecnologias não convencionais.

Apesar de muitas pesquisas estarem sendo conduzidas nessa área, muito ainda deve ser estudado a fim de proporcionar ao consumidor alimentos mais seguros e saudáveis. $\mathrm{O}$ emprego de tecnologias não convencionais, como a irradiação, com a finalidade de garantir a segurança microbiológica de alimentos com teor de sal reduzido é uma área de grande potencial. 


\subsection{Irradiação no processamento de alimentos}

Com o aumento da conscientização e demanda do consumidor por produtos cárneos seguros, nutritivos e saudáveis, as indústrias estão continuamente investigando tecnologias inovadoras para a conservação de alimentos (TROY et al., 2016). Algumas destas tecnologias são: irradiação, micro-ondas, aquecimento ohmico, processamento em alta pressão (HPP), luz ultravioleta, campo eléctrico pulsado (PEF), ultrassom e plasma (OLSEN; GRUNERT; SONNE, 2010; KIM et al., 2012; KANATT et al., 2015; SMEU; NICOLAU, 2014; SHARMA, 2015; TROY et al., 2016).

Dentre as tecnologias utilizadas para a preservação de alimentos, a mais versátil é provavelmente a irradiação (MOY, 2005). Isso pode ser observado na Tabela 1, que ilustra alguns dos seus possíveis usos, relacionando sua função com a dose utilizada. De acordo com Madera-Santana et al. (2016) a irradiação é uma tecnologia eficaz desde a redução de perdas pós- colheita até a garantia da qualidade sanitária dos produtos.

Tabela 1 - Exemplos de doses de radiação utilizada na preservação de alimentos

\begin{tabular}{ccc}
\hline Aplicação & Dose $(\mathbf{K G y})^{\mathbf{a}}$ & Alimento \\
\hline Inibição da germinação & $0,02-0,15$ & Batata, cebola, alho \\
Retardar amadurecimento & $0,12-0,75$ & Banana, manga, mamão \\
Desinfestação de insetos & $0,15-0.50$ & Frutas, castanhas, grãos, frutos \\
secos
\end{tabular}

${ }^{\mathrm{a}}$ Unidade de dose absorvida: 1 Kilogray $=\mathrm{I} \mathrm{kGy}=100 \mathrm{krad}=1 \mathrm{~kJ} / \mathrm{kg}$.

Fonte: Adaptado de Moy (2005) 
As fontes de radiação para alimentos podem ser divididas em três categorias: raios gama, feixe de elétrons e raios-x. Park et al. (2010) afirmam que os raios gama são mais utilizados comercialmente em produtos já embalados devido ao seu maior poder de penetração. A radiação por feixe de elétrons tem poder de penetração limitado. Os raios-X apresentam poder de penetração semelhante aos raios gama gerados a partir do Cobalto 60, entretanto o baixo poder de conversão de elétrons para raios-x é o principal fator que limita a utilização desse tipo de radiação (MOY, 2005).

A dose de radiação pode ser baixa (0,1-1,0 kGy), média (1-10- kGy) e alta (10-100 kGy). Baixas doses de radiação são utilizadas para inibir a germinação de vegetais e para desinfestação de insetos; doses médias atuam de forma similar à pasteurização e têm como principal objetivo aumentar o prazo de validade dos produtos pela eliminação de microrganismos patogênicos e redução dos deteriorantes; altas doses de radiação têm efeito similar ao enlatamento, levando à obtenção de produtos com elevado prazo de validade e que podem ser armazenados sem refrigeração. Utiliza-se de 30 a 50 kGy para esterilização de carnes, frango e frutos do mar (IHSANULLAH; RASHID, 2017).

De acordo com o programa Joint FAO/IAEA, a irradiação de alimentos pode controlar o desenvolvimento de microrganismos patogênicos e deteriorantes, sem afetar significativamente os aspectos sensoriais dos produtos. Entretanto, Kim et al. (2012) estudando linguiça suína fermentada, embalada a vácuo e submetida a radiação gama $(0,5 ; 1$, 2 e 4 kGy), encontraram diferença significativa no sabor das amostras no final do período de armazenamento (90 dias de estocagem a $4^{\circ} \mathrm{C}$ ). Amostras irradiadas com 2 e 4 kGy apresentaram menores notas de aceitação sensorial, quando comparadas à amostras tratadas com 0,5 e 1,0 kGy. Essas últimas amostras não diferiram da amostra controle (não irradiada). Já na análise instrumental de cor, verificou-se aumento do parâmetro a* (intensidade de vermelho) após a irradiação (dia 1), o que eles atribuíram à formação de carboximioglobina 
catalisada pela irradiação. Kanatt, Chawla e Sharma (2015) também relataram aumento no valor de $\mathrm{a}^{*}$ em carnes de frango, cordeiro e búfalo irradiadas com 2,5, 5 e $10 \mathrm{kGy}$. Ao contrário, Ahn et al. (2004) observaram a redução dos valores de a* de linguiça suína cozida imediatamente após a irradiação com doses de 5, 10 e 20 kGy. Eles observaram que quanto maior a dose absorvida, maior a perda de coloração.

Segundo Kim et al. (2012), a irradiação acelera as reações dos radicais livres, levando à mudanças de cor, oxidação lipídica e geração de odores indesejáveis em carnes e produtos cárneos. Park et al (2010) não verificaram diferença significativa nos valores de TBARS de linguiça bovina irradiada com raios gama ou feixe de elétrons com doses de até $10 \mathrm{kGy}$, entretanto verificaram aumento da oxidação lipídica quando foram aplicadas doses superiores a 15 kGy. Kanatt, Chander e Sharma (2006) encontram aumento de $34 \%$ e $89 \%$ dos valores de TBARS de carne de cordeiro irradiada com 2,5 e $5 \mathrm{kGy}$, respectivamente.

\subsubsection{Utilização da radiação gama na produção de alimentos mais seguros}

Uma das formas de aumentar a confiança e a aprovação dos consumidores sobre o uso das tecnologias não convencionais é demonstrar os benefícios que estas tecnologias podem trazer à saúde da população (STRIJBOS et al., 2016). Alguns estudos têm avançado nesta direção: Galán, García e Selgas (2011), propuseram o desenvolvimento de um produto cárneo mais saudável e adequado á necessidade de maior praticidade no momento de consumo exigido pela população. Para isso, utilizaram a radiação (2-4 kGy) na conservação de mortadela fatiada enriquecida com ácido fólico (AF); todas as formulações estudas (0.6, 1.2 and $2.4 \mathrm{mg}$ de AF/100 g de mortadela) foram consideradas como fonte deste composto. Os autores afirmaram que a dose de $4 \mathrm{kGy}$ foi menos preferida pelos consumidores e causou perdas de 20 - $30 \%$ na concentração de AF, mas apesar desta perda, a quantidade de AF que permaneceu no produto foi suficiente para que $50 \mathrm{~g}$ de mortadela fornecesse $100 \%$ da dose diária recomendada deste composto. Fadhel et al. (2016), estudaram a irradiação como 
método para assegurar a segurança microbiológica da carne suína marinada servida a pacientes imunocomprometidos; Os resultados mostraram que a dose de $1 \mathrm{kGy}$ foi suficiente para redução das contagens de E. coli e Salmonela Typhimurium abaixo dos níveis detectáveis durante 28 dias. No caso do C. sporogenes, 1,5 kGy foi suficiente. Os autores afirmam ainda que a irradiação não afetou significativamente os atributos de cor, textura e aceitação global do produto, e as concentrações de tiamina e riboflavina mantiveram-se estáveis durante 14 e 28 dias nos produtos tratados com até 1,5 kGy, respectivamente. Este resultado foi de grande importância, visto que pacientes imunocomprometidos usualmente têm uma dieta pobre em nutrientes devido aos rigorosos processos aplicados na produção dos alimentos que consomem.

\subsubsection{Segurança microbiológica de produtos com reduzida concentração de sódio}

Uma das maiores funções do sal em alimentos é impedir o desenvolvimento de microrganismos (função bacteriostática) (LOBO et al., 2016) e a quantidade de $\mathrm{NaCl}$ em alimentos é um tópico que vem despertando o interesse da população e dos pesquisadores.

Os patógenos causadores de doenças de origem alimentar, dentre os quais se destacam Escherichia coli O157:H7, Salmonella typhimurium, Pseudomonas spp., Listeria monocytogenes, Staphylococcus aureus e Bacillus cereus, causaram 38 milhões de infecções por ano (DUSSAULT; BENOIT; LACROIX, 2012; PARK et al., 2010). A aplicação de radiação em nível médio é capaz de inativar ou reduzir o desenvolvimento destes microrganismos, tornando a carne vermelha, de frango e frutos do mar mais seguras para consumo (MOY, 2005), e assim, viabilizando a redução da concentração de sal nesses produtos.

A inativação de microrganismos indesejáveis em alimentos pela irradiação ocorre pelas alterações químicas provocadas pela aplicação dessa tecnologia no organismo. Tais 
alterações são causadas pela quebra de ligações químicas, que em geral são do tipo covalente em alimentos. A irradiação resulta na formação de radicais hidroxila $(\cdot \mathrm{OH})$ os quais reagem com o DNA dos microrganismos, causando a perda da sua capacidade de reprodução (MOY, 2005).

A irradiação pode ser especialmente útil em produtos cárneos emulsionados, tais como a salsicha, que possuem em sua formulação a carne mecanicamente separada (CMS). A CMS apesar de ser uma excelente estratégia para redução de custos em tais produtos (HORITA et al., 2014), possui muitas particularidades relacionadas à sua composição e características físico químicas que a tornam um produto com reduzida estabilidade (PEREIRA et al., 2011). Assim o estudo da redução de $\mathrm{NaCl}$ em alimentos com CMS em sua composição é de grande importância.

Suklim, Flick Jr. e Vichitphan (2014), conseguiram a inativação completa de duas cepas de Listeria monocytogenes (DMST 1783 e 4553) em carne de caranguejo ao utilizar radiação em doses de 4 e 6 kGy. Dosagens inferiores foram capazes de reduzir a contagem dessa bactéria. Fregonesi et al. (2014) reduziram significativamente o crescimento microbiano em lombo de cordeiro irradiado com 1,5 e 3 kGy, sem comprometer a aceitação sensorial do produto. De acordo com os autores os lombos tratados com $3 \mathrm{kGy}$ se mantiveram seguros para consumo por até 56 dias sob refrigeração $\left(1^{\circ} \mathrm{C}\right)$. Segundo Sommers, Niemira e Fan (2005) a vantagem da utilização da radiação em alimentos, principalmente os prontos para consumo, reside no fato de que esse tratamento pode ser aplicado nos alimentos já embalados, reduzindo assim os riscos de recontaminação. 


\subsection{A percepção do consumidor sobre tecnologias emergentes}

A América do Norte e a Europa são os dois maiores desenvolvedores de inovações para o processamento de alimentos na visão dos consumidores. Recentemente, tais inovações vêm alcançando a América do Sul, especialmente o Brasil (JERMANN et al., 2015).

A adoção efetiva das tecnologias emergentes pela indústria da carne não ocorreu ainda devido a fatores como custos, aumento de escala de produção, falta de conhecimento sobre a utilização, impacto na qualidade do produto, segurança e percepção do consumidor sobre sua utilização (TROY et al., 2016).

Apesar do uso destas tecnologias apresentarem vários benefícios, incluindo o aumento da eficiência dos processos, melhoria da segurança do produto e de atributos de qualidade, maior estabilidade e prazo de vida útil (ROLLIN; KENNEDY; WILLS, 2011; VIDIGAL et al., 2015; TROY et al., 2016), estudos mostraram que os benefícios voltados para o consumidor, como a saúde ou sabor são mais apelativos para estes do que benefícios voltados para o produtor ou para a indústria, tais como aumento da vida útil (SORENSON; HENCHION, 2011; VAN WEZEMAEL et al., 2012).

Mais importante ainda é que, apesar de algumas das tecnologias emergentes possuírem claros benefícios à saúde da população, elas podem não ser aceitas em virtude de diferenças na percepção do conceito de "benefício" entre os consumidores (DE BARCELLOS et al, 2010). Por exemplo, pacientes alérgicos tiveram melhor recepção a alimentos geneticamente modificados contra alergia do que os não alérgicos (FREWER; DE JONGE; VAN KLEEF, 2009); além disso, a tecnologia genética é bem vista quando aplicada a fins medicinais, mas consumidores europeus hesitam em comprar alimentos produzidos com matéria prima geneticamente modificada (SIEGRIST, 2008), o que indica diferenças nas atitudes dos consumidores a depender da região em que ele se encontra. 
De acordo com De Barcellos et al. (2010), existem poucos estudos abordando a reação da população à aplicação de tecnologias emergentes em um determinado alimento, algumas exceções são: o estudo em grupo focal (foccus group) relatado por Nielsen et al. (2009), sobre a percepção do consumidor no uso de alta pressão e campo elétrico pulsado na produção de alimentos (suco e papinha de bebê); o estudo de Evans et al. (2010), que avaliou a "disposição para experimentar" dos consumidores para diferentes tecnologias (pasteurização, inclusão de compostos bioativos, fortificação, reprodução seletiva, modificação genética e nanotecnologia); e ainda o estudo mais recente e amplo publicado por Vidigal et al. (2015), realizado no Brasil e que relata a percepção dos consumidores de iogurte em relação à utilização de matéria prima/processamento novos ou convencionais (pasteurização, orgânicos, geneticamente modificado, enriquecido com proteínas bioativas e nanotecnologia) no processo de fabricação.

Alguns dos estudos citados utilizaram a escala Food Technology Neophobia Scale (FTNS) para acessar a opinião dos participantes. A FTNS se mostrou uma ferramenta válida e confiável na análise de atitudes dos consumidores em relação às novas tecnologias (NTs) para produção de alimentos (EVANS et al., 2010). No questionário, que é mostrado no quadro 1, os entrevistados devem preencher uma escala que varia do 1 (discordo plenamente) ao 7 (concordo plenamente), para cada uma das treze afirmações. O valor total é o somatório dos valores atribuídos para cada item pelos entrevistados. De acordo com os estudos, a neofobia alimentar é influenciada por fatores demográficos, socioeconômicos e falta de informações sobre a tecnologia aplicada. Consumidores de classes mais baixas e com menores níveis de instrução tendem a ser mais neofóbicos que os consumidores de classes mais altas e que possuem maior contato com NTs (VIDIGAL et al., 2015). Consumidores europeus são mais desconfiados que americanos e necessitam de maior transparência e informações sobre os produtos antes de aceitá-los (ROLLIN; KENNEDY; WILLS, 2011). 
A atitude do consumidor frente às NTs irá determinar o seu sucesso ou fracasso no mercado, por isso é de extrema importância avaliar a sua aceitação antes de arriscar o lançamento do novo produto.

\subsection{Percepção do consumidor}

A percepção do consumidor sobre um produto ou tecnologia pode ser acessada por diferentes técnicas. A seguir serão descritas algumas de importância no desenvolvimento deste projeto.

\subsubsection{Neofobia Alimentar}

A dieta humana é caracterizada pelo equilíbrio entre 1) a demanda impulsionada pela curiosidade pela novidade (neofilia) e 2) a grande cautela, às vezes aversão, sobre o novo ou o desconhecido (neofobia) (BILTEKOFF, 2010). O estudo da interação neofobia / neofilia é cada vez mais importante na análise do comportamento do consumidor, uma vez que esse comportamento envolve processos cognitivos altamente complexos (VERNEAU et al., 2014).

A neofobia alimentar é caracterizada como um traço de personalidade em função do qual as pessoas podem ser classificadas a depender da sua tendência em aceitar ou rejeitar novos alimentos (SCHNETTLER et al., 2013). A fim de medir os níveis de neofobia entre consumidores, Pliner e Hobden (1992) desenvolveram um instrumento psicométrico denominado de escala de neofobia alimentar (Food neophobia scale - FNS), na qual os indivíduos indicariam o seu nível de concordância com dez itens relacionados aos alimentos e situações relacionadas com a alimentação (BARRENA; SÁNCHEZ, 2013).

Em 2008, Cox e Evans desenvolveram a Food Technology Neophobia Scale (FTNS) (COX; EVANS, 2008), uma escala sob a forma de questionário contendo 13 itens que avalia especificamente a neofobia em relação a tecnologias aplicadas no processamento de um alimento, e não ao alimento propriamente dito. Os itens do questionário são apresentados na 
forma de declarações em que o entrevistado deve expressar sua opinião utilizando uma escala de concordância (variando de $1=$ discordo extremamente a $7=$ concordo extremamente). Alguns estudos (FREWER et al., 2011; ROLLIN; KENNEDY; WILLS, 2011; VERNEAU et al., 2014) já utilizaram esta escala para relacionar a neofobia alimentar não apenas com a aceitação de novos alimentos, mas também com a aceitação de tecnologias não convencionais utilizadas na produção e processamento destes alimentos. O questionário foi traduzido e validado para a português por Vidigal et al. (2014) (Quadro 1). A FTNS é indicada como melhor ferramenta para avaliar os receios dos consumidores em relação às tecnologias aplicadas no processamento de alimentos, em comparação com a anteriormente citada (FNS), devido ao seu foco específico na tecnologia em vez de no alimento propriamente dito (EVANS et al., 2010; MARTIN et al., 2012; VERNEAU et al., 2014).

Como limitação do método, alguns pesquisadores (VERNEAU et al., 2014; VIDIGAL et al., 2015) citam que o questionário não leva em consideração fatores demográficos e culturais, o que torna necessária a sua aplicação em diferentes regiões.

Quadro 1 - Questões do questionário FTNS traduzidas por Vidigal et al., 2014.

\begin{tabular}{|c|}
\hline Itens \\
\hline $\begin{array}{l}1 \text { Eu não estou totalmente familiarizado com tecnologias não convencionais empregadas na produção e/ou } \\
\text { processamento de alimentos. }\end{array}$ \\
\hline 2 Novos alimentos não são mais saudáveis do que os alimentos tradicionais. \\
\hline $\begin{array}{l}3 \text { As afirmações sobre os benefícios de tecnologias não convencionais empregadas na produção e/ou } \\
\text { processamento de alimentos são frequentemente muito exageradas. }\end{array}$ \\
\hline $\begin{array}{l}4 \text { Já existem inúmeros alimentos saborosos no mercado, então nós não precisamos de tecnologias não } \\
\text { convencionais para produzir mais alimentos. }\end{array}$ \\
\hline $\begin{array}{l}5 \text { Tecnologias não convencionais empregadas na produção e/ou processamento de alimentos reduzem a } \\
\text { qualidade natural dos alimentos. }\end{array}$ \\
\hline $\begin{array}{l}6 \text { Tecnologias não convencionais empregadas na produção e/ou processamento de alimentos provavelmente não } \\
\text { trarão, a longo prazo, efeitos negativos à saúde. }\end{array}$ \\
\hline $\begin{array}{l}7 \text { Tecnologias não convencionais empregadas na produção e/ou processamento de alimentos proporcionam às } \\
\text { pessoas um maior controle sobre as suas escolhas alimentares. }\end{array}$ \\
\hline $\begin{array}{l}8 \text { Novos produtos que utilizam tecnologias não convencionais de alimentos podem ajudar as pessoas a terem } \\
\text { uma dieta equilibrada. }\end{array}$ \\
\hline $\begin{array}{l}9 \text { Tecnologias não convencionais empregadas na produção e/ou processamento de alimentos podem causar, a } \\
\text { longo prazo, efeitos negativos ao meio ambiente. }\end{array}$ \\
\hline $\begin{array}{l}10 \text { Pode ser arriscado mudar rapidamente para tecnologias não convencionais empregadas na produção e/ou } \\
\text { processamento de alimentos. }\end{array}$ \\
\hline \\
\hline
\end{tabular}


12 Não faz sentido experimentar alimentos produzidos a partir de alta tecnologia, porque os que eu consumo já são bons o suficiente.

13 A mídia geralmente fornece uma visão equilibrada e imparcial das tecnologias não convencionais empregadas na produção e/ou processamento de alimentos

Fonte: Vidigal et al. (2014).

É possível ainda relacionar o nível de neofobia da população com a sua disposição para experimentar alimentos processados com tecnologias não convencionais ou com novos ingredientes. Vidigal et al (2015) mostraram que a disposição para experimentar produtos transgênicos ou com nanotecnologia foi menor do que a para produtos produzidos com outras tecnologias mais usuais. Esta avaliação foi realizada com o auxílio de uma escala não estruturada ancorada nos extremos com 1- Nem um pouco disposto e 7 - Extremamente disposto a experimentar.

\subsubsection{Focus group}

A atitude do consumidor em relação a um produto é melhor estudada em um ambiente em que os inquiridos são estimulados a formar novas atitudes devido a ações externas, como novas informações sobre os objetos estudados, e em locais onde eles acham natural verbalizar suas respostas cognitivas para essa nova informação. O focus group proporciona o ambiente adequado para isso, uma vez que os participantes são estimulados tanto pela informação fornecida pelos investigadores quanto por comentários de outros participantes, sendo então naturalmente instigados a verbalizar suas ideias (NIELSEN et al., 2009).

Um focus group é, portanto, um método de pesquisa qualitativa, no qual um moderador (também chamado de facilitador) orienta um grupo de cinco a doze participantes (selecionados a partir de requisitos pré-estabelecidos) por meio de uma série de perguntas ou exercícios relacionados a um tópico específico em um ambiente aprazível (WILSON, 2014). Este método aproveita a interação entre os membros do grupo para melhorar a coleta de informações sobre crenças e perspectivas fortemente arraigadas. Esta abordagem é 
especialmente útil para explorar novos temas e examinar questões complexas envolvendo valores e crenças que fundamentam o comportamento das pessoas (CAREY, 2016).

\subsubsection{Check-all-that-apply (CATA)}

CATA é uma ferramenta de avaliação sensorial que permite aos entrevistados selecionar todos os atributos que eles consideram relevantes em um produto, ao invés de forçá-los a analisar atributos específicos ou escolher uma única resposta (DOS SANTOS, et al., 2015; JORGE et al., 2015). Para cada amostra, uma lista pré-definida de descritores sensoriais é apresentada e os participantes são instruídos a selecionar todos que se aplicam (ARES et al., 2010a). Os atributos são mais fáceis de entender e o método é mais rápido do que os métodos que utilizam avaliadores treinados (ARES et al., 2010b; JORGE et al., 2015). 


\section{REFERÊNCIAS}

ANVISA, Portaria $\mathrm{n}^{\circ}$ 1004, de 11 de dezembro de 1998. Aprova o Regulamento Técnico: "Atribuição de Função de Aditivos, Aditivos e seus Limites Máximos de uso para a Categoria 8 - Carne e Produtos Cárneos".

AASLYNG, Margit Dall; VESTERGAARD, Christian; KOCH, Anette Granly. The effect of salt reduction on sensory quality and microbial growth in hotdog sausages, bacon, ham and salami. Meat Science, v. 96, n. 1, p. 47-55, 2014.

ABIA - Associação Brasileira das Indústrias de Alimentação. KLOTZ,E. Cenário do consumo de sódio no Brasil.2013. Disponível em <

http://www.alimentosprocessados.com.br/arquivos/Ingredientes-e-aditivos/Cenario-doconsumo-de-sodio-no-Brasil-ABIA.pdf>, acesso em 21 jun 2019.

AHN, H.J. et al. Effects of gamma irradiation on residual nitrite, residual ascorbate, color, and N-nitrosamines of cooked sausage during storage. Food Control, v. 15, p. 197-203, 2004.

AMAKO, Donatus EN; XIONG, Youling L. Effects of carrageenan on thermal stability of proteins from chicken thigh and breast muscles. Food Research International, v. 34, n. 2, p. 247-253, 2001.

AOAC Official Methods of Analysis of the Association of Official Analytical Chemists, Method 982.22 (16th ed.), Gaithersburg, 1997.

ARES, Gastón et al. Comparison of two sensory profiling techniques based on consumer perception. Food Quality and Preference, v. 21, n. 4, p. 417-426, 2010 a.

ARES, Gaston et al. Application of a check-all-that-apply question to the development of chocolate milk desserts. Journal of Sensory Studies, v. 25, n. s1, p. 67-86, 2010b.

BARRENA, Ramo; SÁNCHEZ, Mercedes. Neophobia, personal consumer values and novel food acceptance. Food Quality and Preference, v. 27, n. 1, p. 72-84, 2013.

BIBBINS-DOMINGO K. et al. Projected effect of dietary salt reductions on future cardiovascular disease. New England Journal of Medicine, v. 362, n.7, p. 590-599, 2010.

BILTEKOFF, Charlotte. Consumer response: the paradoxes of food and health. Annals of the New York Academy of Sciences, v. 1190, n. 1, p. 174-178, 2010.

BOBOWSKI, N.; RENDAHL, A.; VICKERS, Z. Preference for salt in a food may be alterable without a low sodium diet. Food Quality and Preference, v. 39, p. 40-45, 2015.CAREY, Martha Ann; ASBURY, Jo-Ellen. Focus group research. Routledge, 2016. CAREY, Martha Ann. Focus groups. International Encyclopedia of the Social \& Behavioral Sciences, p. 274-279, 2015.

COX, D. N.; EVANS, G. Construction and validation of a psychometric scale to measure consumers' fears of novel food technologies: The food technology neophobia scale. Food quality and preference, v. 19, n. 8, p. 704-710, 2008. 
DATTA, A. K.; RAKESH, V. Principles of microwave combination heating.Comprehensive Reviews in Food Science and Food Safety, v. 12, n. 1, p. 24-39, 2013.

DE BARCELLOS, Marcia D. et al. European consumers' acceptance of beef processing technologies: A focus group study. Innovative Food Science \& Emerging Technologies, v. 11, n. 4, p. 721-732, 2010.

DING, Yi et al. Nutritional composition in the chia seed and its processing properties on restructured ham-like products. journal of food and drug analysis, v. 26, n. 1, p. 124-134, 2018.

DOS SANTOS, B. A. et al. Monosodium glutamate, disodium inosinate, disodium guanylate, lysine and taurine improve the sensory quality of fermented cooked sausages with $50 \%$ and 75\% replacement of $\mathrm{NaCl}$ with $\mathrm{KCl}$. Meat science, v. 96, n. 1, p. 509-513, 2014.

DOS SANTOS, B. A. et al. Check all that apply and free listing to describe the sensory characteristics of low sodium dry fermented sausages: comparison with trained panel. Food Research International, v. 76, p. 725-734, 2015.

DOYLE, Marjorie Ellin; GLASS, Kathleen A. Sodium reduction and its effect on food safety, food quality, and human health. Comprehensive Reviews in Food Science and Food Safety, v. 9, n. 1, p. 44-56, 2010.

DUSSAULT, D.; BENOIT, C; LACROIX, M. Combined effect of g-irradiation and bacterialfermented dextrose on microbiological quality of refrigerated pork sausages. Radiation Physics and Chemistry, v. 81, p. 1098-1102, 2012.

EVANS, G. et al. Reliability and predictive validity of the Food Technology Neophobia Scale. Appetite, v. 54, n. 2, p. 390-393, 2010.

FDA. Guidance for Industry: A Food Labeling Guide 9- Appendix A: Definitions of Nutrient Content Claims. 2013 Disponível em < https://www.fda.gov/Food/GuidanceRegulation/GuidanceDocumentsRegulatoryInformation/ LabelingNutrition/ucm064911.htm> Acesso em 30 jul 2017.

FADHEL, Yosra Ben et al. Combined effects of marinating and $\gamma$-irradiation in ensuring safety, protection of nutritional value and increase in shelf-life of ready-to-cook meat for immunocompromised patients. Meat science, v. 118, p. 43-51, 2016.

FELISBERTO, Mária Herminia Ferrari et al. Effect of prebiotic ingredients on the rheological properties and microstructure of reduced-sodium and low-fat meat emulsions. LWT-Food Science and Technology, v. 60, n. 1, p. 148-155, 2015.

FREGONESI, R. P. et al. Irradiated vacuum-packed lamb meat stored under refrigeration: Microbiology, physicochemical stability and sensory acceptance. Meat science, v. 97, n. 2, p. 151-155, 2014.

FREWER, Lynn; DE JONGE, Janneke; VAN KLEEF, Ellen. Consumer perceptions of food safety. Medical Sciences-Volume II, p. 243, 2009. 
FREWER, L. J. et al. Consumer response to novel agri-food technologies: implications for predicting consumer acceptance of emerging food technologies. Trends in Food Science \& Technology, v. 22, n. 8, p. 442-456, 2011.

FURLÁN, Laura T. Rodriguez; PADILLA, Antonio Pérez; CAMPDERRÓS, Mercedes E. Development of reduced fat minced meats using inulin and bovine plasma proteins as fat replacers. Meat Science, v. 96, n. 2, p. 762-768, 2014.

GALÁN, I.; GARCÍA, M.A.L; SELGAS, M. A.D. Irradiation is useful for manufacturing ready-to-eat cooked meat products enriched with folic acid. Meat science, v. 87, n. 4, p. 330335, 2011.

GROSSI, A. et al. Reduction of salt in pork sausages by the addition of carrot fibre or potato starch and high pressure treatment. Meat Science, Amsterdam, v. 92, p.481-489, 2012.

HORITA, C.N., et al. Textural, microstructural and sensory properties of reduced sodium frankfurter sausages containing mechanically deboned poultry meat and blends of chloride salts. Food Research International, Kidlington, v. 66, p. 29-35, 2014.

IHSANULLAH, I.; RASHID, Azhar. Current activities in food irradiation as a sanitary and phytosanitary treatment in the Asia and the Pacific Region and a comparison with advanced countries. Food control, v. 72, p. 345-359, 2017.

JERMANN, Colette et al. Mapping trends in novel and emerging food processing technologies around the world. Innovative Food Science \& Emerging Technologies, v. 31, p. 14-27, 2015.

Joint FAO/ IAEA Programme - Nuclear Techniques in Food and Agriculture. Food Irradiation. Disponível em < http://www-naweb.iaea.org/nafa/fep/topic-foodirradiation.html $>$ Acesso em 24-mar-2016.

JORGE, É. da C. et al. Application of a check-all-that-apply question for evaluating and characterizing meat products. Meat science, v. 100, p. 124-133, 2015.

KANATT, S.R.; CHANDER, R.; SHARMA, A. Effect of radiation processing of lamb meat on its lipids. Food Chemistry, v. 97, p. 80-86, 2006.

KANATT, S.R.; CHAWLA, S.P.; SHARMA, A. Effect of radiation processing on meat tenderization. Radiation Physics and Chemistry, v. 111, p. 1-8, 2015.

KIM, I.S. et al. Effects of low-level gamma irradiation on the characteristics of fermented pork sausage during storage. Radiation Physics and Chemistry, v. 81, p. 466-472, 2012.

KNOERZER, Kai. Nonthermal and Innovative Food Processing Technologies. Reference Module in Food Science, 2016. Doi: http://dx.doi.org/10.1016/B978-0-08-100596-5.03414$\underline{4}$.

LILIC, S. et al. Reducing sodium chloride content in meat burgers by adding potassium chloride and onion. Procedia Food Science, v. 5, p. 164 - 167, 2015. 
LOBO, F. et al. Underlying chemical mechanisms of the contradictory effects of $\mathrm{NaCl}$ reduction on the redox-state of meat proteins in fermented sausages. LWT - Food Science and Technology, v. 69, p. $110-116,2016$.

MADERA-SANTANA et al. Effect of gamma irradiation on physicochemical properties of commercial poly (lactic acid) clamshell for food packaging. Radiation Physics and Chemistry, v. 123, p. 6-13, 2016.

MCGOUGH, Megan M. et al. Reducing sodium levels in frankfurters using a natural flavor enhancer. Meat science, v. 91, n. 2, p. 185-194, 2012.

MORA-GALLEGO, Héctor et al. Effect of reducing and replacing pork fat on the physicochemical, instrumental and sensory characteristics throughout storage time of small caliber non-acid fermented sausages with reduced sodium content. Meat science, v. 97, n. 1, p. 62-68, 2014.

MOY, J.H. Food Irradiation - An emerging technology. In: BARBOSA-CÁNOVAS, G.V.; TAPIA, M.S.; PILAR CANO, M. Novel Food Processing Technologies, CRC Press, United States of America, 2005.

MYERS, K. et al. The effect of high hydrostatic pressure, sodium nitrite and salt concentration on the growth of Listeria monocytogenes on RTE ham and turkey. Meat Science, Amsterdam, v. 93, p. 263-268, 2013.

NATIONAL RESEARCH COUNCIL (NRC). Recommended dietary allowances. 10. ed. Washington: National Academy Press, 1989.

NIELSEN, Henriette Boel et al. Consumer perception of the use of high-pressure processing and pulsed electric field technologies in food production. Appetite, v. 52, n. 1, p. 115-126, 2009.

OLSEN, Nina Veflen; GRUNERT, Klaus G.; SONNE, Anne-Mette. Consumer acceptance of high-pressure processing and pulsed-electric field: a review.Trends in Food Science \& Technology, v. 21, n. 9, p. 464-472, 2010.

OMANA, D.A.; PLASTOW, G.; BETTI, M. Effect of different ingredients on color and oxidative characteristics of high pressure processed chicken breast meat with special emphasis on use of $\beta$-glucan as a partial salt replacer. Innovative Food Science and Emerging Technologies, Amsterdam, v. 12, p. 244-254, 2011.

PARK, J.G. et al. Effects of gamma irradiation and electron beam irradiation on quality, sensory, and bacterial populations in beef sausage patties. Meat Science, v. 85, p. 368-372, 2010.

PEREIRA, Anirene Galvão Tavares et al. Effects of the addition of mechanically deboned poultry meat and collagen fibers on quality characteristics of frankfurter-type sausages. Meat science, v. 89, n. 4, p. 519-525, 2011.

PERREA, Toula; GRUNERT, Klaus G.; KRYSTALLIS, Athanasios. Consumer Value perceptions of food products from emerging processing technologies: A cross-cultural exploration. Food Quality and Preference, v. 39, p. 95-108, 2015. 
PUOLANNE, E.J.; RUUSUNEN, M.H.; VAINIONPAA, J.I. Combined effects of $\mathrm{NaCl}$ and raw meat $\mathrm{pH}$ on water-holding in cooked sausage with and without added phosphate. Meat Science, v. 58, p. 1-7, 2001.

REEVE, B.; MAGNUSSON, R. Food reformulation and the (neo)-liberal state: new strategies for strengthening voluntary salt reduction programs in the UK and USA. P u b l i c health, v. 129 , p. $351-363,2015$.

ROLLIN, Fanny; KENNEDY, Jean; WILLS, Josephine. Consumers and new food technologies. Trends in Food Science \& Technology, v. 22, n. 2, p. 99-111, 2011.

RUUSUNEM, M. el al. Reducing the sodium content in meat products: The effect of the formulation in low-sodium ground meat patties. Meat Science, Amsterdam, v. 69, p. 53-60, 2005 .

SCHNETTLER, Berta et al. Food neophobia, nanotechnology and satisfaction with life. Appetite, v. 69, p. 71-79, 2013.

SIEGRIST, Michael. Factors influencing public acceptance of innovative food technologies and products. Trends in Food Science \& Technology, v. 19, n. 11, p. 603-608, 2008.

SMEU, Irina; NICOLAU, Anca Ioana. ENHANCEMENT OF FOOD SAFETYANTIMICROBIAL EFFECTIVENESS OF COLD PLASMA TREATMENTS.The Annals of the University of Dunarea de Jos of Galati. Fascicle VI. Food Technology, v. 38, n. 1, p. 9, 2014.

SOMMERS, C.H.; NIEMIRA, B.A.; FAN, X. ARS continues advances in irradiation of ready to eat foods. Agricultural research, v. 53, n. 2, p. 10-13, 2005. Disponível em $<$ http://go.galegroup.com/ps/i.do?\&id=GALE|A128709808\&v=2.1\&u=capes\&it=r\&p=AON $\mathrm{E} \& \mathrm{sw}=\mathrm{w}>$ Acesso em 24-mar-2016.

SORENSON, Douglas; HENCHION, Maeve. Understanding consumers' cognitive structures with regard to high pressure processing: A means-end chain application to the chilled ready meals category. Food Quality and Preference, v. 22, n. 3, p. 271-280, 2011.

SOUSA, Samara C. et al. Quality parameters of frankfurter-type sausages with partial replacement of fat by hydrolyzed collagen. LWT-Food Science and Technology, v. 76, p. 320-325, 2017.

STRIJBOS, C. et al. Consumer awareness and credibility factors of health claims on innovative meat products in a cross-sectional population study in the Netherlands. Food Quality and Preference, v. 54, p. 13-22, 2016.

SUKLIM, K.; FLICK JR., G. J.; VICHITPHAN, K. Effects of gamma irradiation on the physical and sensory quality and inactivation of Listeria monocytogenes in blue swimming crab meat (Portunas pelagicus). Radiation Physics and Chemistry, v. 103, p. 22-26, 2014.

SYARIFUDDIN, A. et al. Reducing salt and fat while maintaining taste: An approach on a model food system. Food Quality and Preference, v. 48, p. 59-69, 2016. 
TAMM, Alina et al. Salt $(\mathrm{NaCl})$ reduction in cooked ham by a combined approach of high pressure treatment and the salt replacer $\mathrm{KCl}$. Innovative Food Science \& Emerging Technologies, v. 36, p. 294-302, 2016.

TOTOSAUS, Alfonso; PEREZ-CHABELA, M. Lourdes. Textural properties and microstructure of low-fat and sodium-reduced meat batters formulated with gellan gum and dicationic salts. LWT-Food Science and Technology, v. 42, n. 2, p. 563-569, 2009.

TROY, Declan J. et al. Sustainable and consumer-friendly emerging technologies for application within the meat industry: An overview. Meat science, 2016.

UNITED STATES DEPARTMENT OF AGRICULTURE - USDA. 2010. Dietary guidelines for Americans. Disponível em <http://www.cnpp.usda.gov/dietaryguidelines.htm>. Acesso em mar, 2016.

VAN WEZEMAEL, Lynn et al. The effect of technology information on consumer expectations and liking of beef. Meat science, v. 90, n. 2, p. 444-450, 2012.

VERNEAU, Fabio et al. Consumer fears and familiarity of processed food. The value of information provided by the FTNS. Appetite, v. 73, p. 140-146, 2014.

VIDIGAL, Márcia Cristina Teixeira Ribeiro et al. Tradução e validação para a língua portuguesa da escala de neofobia em relação à tecnologia de alimentos: food technology neophobia scale. Ciência Rural, v. 44, n. 1, p. 174-180, 2014.

VIDIGAL, Márcia CTR et al. Food technology neophobia and consumer attitudes toward foods produced by new and conventional technologies: A case study in Brazil. LWT-Food Science and Technology, v. 60, n. 2, p. 832-840, 2015.

WORLD HEALTH ORGANIZATION - WHO. Prevention of recurrent heart attacks and strokes in low and middle income populations: Evidence-based recommendations for policy makers and health professionals. Geneva, World Health Organization (WHO), 2003 WORLD HEALTH ORGANIZATION -WHO. Global status report on noncommunicable diseases. Geneva, World Health Organization (WHO), 2010.

WORLD HEALTH ORGANIZATION -WHO Guideline: Sodium intake for adults and children. Geneva, World Health Organization (WHO), 2014a.

WORLD HEALTH ORGANIZATION - WHO, 2014b. Salt Reduction. Disponível em < http://www.who.int/mediacentre/factsheets/fs393/en/> Acesso em mar. 2016.

WILSON, Chauncey. Chapter 5 - Focus group. In: Wilson, C. Interview Techniques for UX Practitioners, Elsevier, 2014.

WRIGHT, David J.; LEACH, Ian B.; WILDING, Peter. Differential scanning calorimetric studies of muscle and its constituent proteins. Journal of the Science of Food and Agriculture, v. 28, n. 6, p. 557-564, 1977.

WU, Lijun et al. Effects of cations on the "salt in" of myofibrillar proteins. Food Hydrocolloids, v. 58, p. 179-183, 2016. 
YOUSSEF, M. K.; BARBUT, S. Fat reduction in comminuted meat products-effects of beef fat, regular and pre-emulsified canola oil. Meat Science, v. 87, n. 4, p. 356-360, 2011.

YOTSUYANAGI, S. et al. Technological, sensory and microbiological impacts of sodium reduction in frankfurters. Meat Science, v., 115, p. 50-59, 2016. 
CAPÍtulo I - ENTENDENDO A REDUÇÃO DE SAL EM SALSICHAS COM REDUZIDA CONCENTRAÇÃO DE GORDURA: ESTRUTURA DA REDE, ESTABILIDADE DA EMULSÃO E ACEITAÇÃO DO CONSUMIDOR

Artigo: “UNDERSTANDING SALT REDUCTION IN FAT-REDUCED HOT DOG SAUSAGES: NETWORK STRUCTURE, EMULSION STABILITY AND CONSUMER ACCEPTANCE"

Isabela Rodrigues*, Letícia A. Gonçalves, Francisco A.L. Carvalho, Manoela Pires, Yana J. P. Rocha, Julliane C. Barros, Larissa T. Carvalho, Marco A. Trindade 


\section{RESUMO}

Teores elevados de sódio e gordura são motivos de preocupação para indústrias e consumidores de produtos cárneos. A redução direta de $\mathrm{NaCl}$ e gordura é uma estratégia útil para entender como esses ingredientes interferem nos parâmetros de qualidade de um produto cárneo emulsionado e como reduzi-los sem alterações significativas do produto original. O objetivo deste trabalho foi compreender a redução de sal em salsichas reduzidas em gordura (10g de gordura / $100 \mathrm{~g}$ de produto). Cinco concentrações de $\mathrm{NaCl}$ foram testadas: $1 \%$ (F1), 1,25\% (F1.25), $1,50 \%$ (F1.50), 1,75\% (F1.75) e 2\% (F2 - controle). Foram avaliados: composição centesimal, teor de sódio, atividade de água, $\mathrm{pH}$, estabilidade da emulsão, cor instrumental, textura, microscopia eletrônica de varredura (MEV) e atributos sensoriais (justabout-right para sabor salgado e teste afetivo de aceitação). A estabilidade da emulsão diminuiu $(\mathrm{P}<0,05)$ com a redução de sal. A redução de $\mathrm{NaCl}$ aumentou a atividade de água. Imagens MEV mostraram uma matriz mais compacta com a diminuição do teor de sal. Salsichas com as quantidades mínimas (F1) e máximas (F2) de sal foram menos aceitas pelos consumidores. Pôde-se obter uma redução de 26,8\% de sódio (F1.25), permitindo a rotulagem de salsicha com teor reduzido de sódio e com aceitação pelos consumidores.

Palavras-chave: Sal, produtos de carne, produtos emulsificados 


\section{INTRODUÇÃO}

Reduções de sódio e gordura em produtos cárneos são grandes preocupações para consumidores e indústrias. A principal fonte de sódio em produtos cárneos é o $\mathrm{NaCl}$ adicionado. Em produtos cárneos emulsionados, devido às funções do $\mathrm{NaCl}$, a redução de sódio é um tópico que ainda precisa ser explorado. A redução de gordura também é uma tendência contínua, e enfrenta desafios como alterações no sabor e textura dos produtos acabados (YOUSSEF; BARBUT, 2011).

Emulsões cárneas podem ser definidas como uma rede tridimensional (3D), formada por interações de proteínas, gordura, água e sais (KEENAN et al., 2014). Nesses produtos, o sal $(\mathrm{NaCl})$ está envolvido em três interações importantes: proteína-água (retenção de água), proteína-gordura (ligação de gordura) e proteína-proteína (ligação da proteína) (KILCAST; ANGUS, 2007).

Na interação proteína-água, os íons cloreto penetram os miofilamentos proteicos, enquanto os íons sódio formam uma nuvem ao redor do filamento. Esse arranjo resulta em diferenças na concentração do meio, promovendo aumento da pressão osmótica nas miofibrilas e inchaço do filamento (PUOLANNE; RUUSUNEN; VAINIONPÄ̈̈, 2001). Quando as miofibrilas estão inchadas, a capacidade de ligação da água é melhor (TAMM et al., 2016), portanto em meios com menos sódio, a capacidade de retenção de água será prejudicada. Segundo Laranjo et al. (2016), quando a capacidade da proteína em reter água diminui há alterações na textura e no rendimento do produto. Em produtos emulsionados, o $\mathrm{NaCl}$ atua também como agente solubilizante, estabilizando a gordura dentro da matriz protéica (interação proteína-gordura), contribuindo para a suculência e textura (KEENAN et al., 2014). Além disso, o $\mathrm{NaCl}$ promove a solubilização de proteínas miofibrilares e as interações proteína-proteína, uma função essencial no processamento de produtos cárneos. 
Segundo Aaslyng, Vestergaard e Koch (2014), a redução de sódio em salsichas até 1,7\% não causa alterações significativas nos parâmetros de rendimento, atributos sensoriais, contagem de bactérias lácticas ou coliformes totais. No entanto, níveis inferiores a 1,7\% podem resultar em mudanças significativas nas propriedades sensoriais e redução no prazo de validade. Finalmente, o $\mathrm{NaCl}$ age como um intensificador de sabor. McGough et al. (2012) argumentam que, na busca por estratégias voltadas à redução de sódio, é fundamental estudar maneiras de manter o sabor tradicionalmente salgado associado à carne processada, evitando a introdução de sabores não tradicionais, que são frequentemente rejeitados pelo consumidor.

A gordura está envolvida em vários atributos de qualidade em produtos cárneos, por exemplo, textura, sabor e propriedades tecnológicas (SOUSA et al, 2017; YOUSSEF; BARBUT, 2011). Segundo Ding et al. (2017), produtos cárneos com baixo teor de gordura apresentam textura mais dura, menor suculência e alterações no sabor. Consequentemente, esses produtos podem ter sua aceitabilidade prejudicada (MORA-GALLEGO et al., 2014).

Salsichas têm uma textura homogênea e macia, o que as torna muito atrativas, especialmente para crianças e idosos (KOWALCZEWSKI et al., 2015). A gordura é incorporada a esses produtos devido às suas características sensoriais peculiares e seu papel estrutural (CONROY et al., 2018).

De modo a compreender melhor como a redução de sal interfere nos parâmetros de qualidade de um produto cárneo emulsionado, é primordial estudar o comportamento destes produtos quando o $\mathrm{NaCl}$ é diretamente reduzido, isto é, sem substituir por outros sais. Neste trabalho, avaliou-se o impacto de várias concentrações de $\mathrm{NaCl}(2 \%, 1,75 \%, 1,5 \%, 1,25 \%$ e 1\%) sobre as características tecnológicas e aceitação sensorial de salsichas reduzidas em gordura. 


\section{MATERIAIS E MÉTODOS}

\subsection{Preparação de salsichas}

Cinco formulações de salsicha foram produzidas com os seguintes níveis de $\mathrm{NaCl}$ : $1 \mathrm{~g}$ / $100 \mathrm{~g}(\mathrm{~F} 1), 1,25 \mathrm{~g} / 100 \mathrm{~g}(\mathrm{~F} 1.25), 1,50 \mathrm{~g} / 100 \mathrm{~g}(\mathrm{~F} 1.50), 1,75 \mathrm{~g} / 100 \mathrm{~g}(\mathrm{~F} 1.75)$ e 2,0 g / $100 \mathrm{~g}$ (F2 - controle). As formulações foram calculadas para ter $10 \mathrm{~g}$ de gordura / $100 \mathrm{~g}$ produto, o que representa um terço da gordura em relação aos produtos comumente encontrados no mercado brasileiro (até $30 \%$ de gordura). As quantidades dos outros ingredientes foram as mesmas para todas as formulações: $60 \mathrm{~g} / 100 \mathrm{~g}$ de dianteiro bovino moído, 9,5 g / $100 \mathrm{~g}$ de toucinho, 2,0 g / $100 \mathrm{~g}$ de amido, 0,5 g / $100 \mathrm{~g}$ de condimento para salsicha (New Max Industrial Ltda, Americana, SP, Brasil), 0,05 g / $100 \mathrm{~g}$ de eritorbato de sódio, 0,25 g / $100 \mathrm{~g}$ de tripolifosfato de sódio, 0,015 g / 100 g de nitrito de sódio e 0,05 g / 100 g de carmim de cochonilha. Adicionou-se água/gelo às formulações na quantidade necessária para completar $100 \%$ de massa em cada batelada. Três bateladas de oito quilos foram produzidas para cada formulação (três repetições do experimento).

Os ingredientes foram pesados separadamente e misturados em um homogeneizador de bacia rotativa (Cutter - Tecmafrig, São Paulo, Brasil) até que uma emulsão fosse obtida (velocidade constante, 14 minutos). A temperatura foi mantida abaixo de $14{ }^{\circ} \mathrm{C}$ durante todo o processo. A massa obtida foi embutida em tripas celulósicas ( $23 \mathrm{~mm}$ de diâmetro, Viscofan do Brasil, SP, Brasil) e cozida em estufa (SL 218 Arprotec, Valinhos, Brasil) até atingir a temperatura interna de $72{ }^{\circ} \mathrm{C}$. As salsichas foram resfriadas com água corrente e refrigeradas por 16 horas $\left(4^{\circ} \mathrm{C}\right)$. Em seguida, a tripa foi removida, e as salsichas foram embaladas a vácuo e refrigeradas $\left(4^{\circ} \mathrm{C}\right)$ para posterior análise. 


\subsection{Composição centesimal e concentração de sódio}

Os métodos da Association of Analytical Chemists (AOAC - CUNNIF, 1998) foram adotados para determinação de proteínas $(981,10)$, lipídios $(991,36)$, umidade $(950,46)$ e cinzas $(920,153)$. As determinações foram feitas em quatro amostras para cada formulação em cada repetição.

O teor de sódio foi quantificado por meio de espectrofotômetro de chama (MICRONAL, B462, Brasil) e os resultados foram expressos em mg x 100 g-1. Para a análise, $5 \mathrm{~g}$ de cada amostra foram incinerados em uma mufla a $550{ }^{\circ} \mathrm{C}$. Os testes foram realizados de acordo com a AOAC $(9565.01,1997)$.

\subsection{Atividade de água (Aa)}

A atividade de água foi determinada em três amostras para cada formulação em cada repetição, utilizando o equipamento Aqualab (Decagon Devices, Pullman, WA). Salsichas foram trituradas por 2 minutos em multiprocessador (Philips Walita) antes das análises.

\subsection{Microscopia Eletrônica de Varredura (MEV)}

Para análise de MEV foi utilizado o protocolo de Haga e Ohashi (1984). Resumidamente, salsichas de cada tratamento foram cortadas em tiras de aproximadamente $0,5 \mathrm{~mm}$ de espessura e liofilizadas por $48 \mathrm{~h}$ para remover a umidade. As amostras secas foram visualizadas sob o microscópio eletrônico de varredura (Mark Hitachi, Japão), com ampliações de 50, 100 e 500 x.

\subsection{Análise de perfil de textura (TPA)}

O perfil de textura instrumental foi avaliado com uso de texturômetro (TAXT2i, Stable Micro Systems, Godalming, UK). As amostras foram cortadas em cilindros $(2 \mathrm{~cm}$ de 
altura, $2 \mathrm{~cm}$ de diâmetro) e comprimidas duas vezes a 50\% do seu tamanho com o probe P-35, a $2 \mathrm{~mm}$ / s de velocidade (pré teste, teste e pós teste). Os parâmetros estudados foram: dureza (g), elasticidade (adimensional), coesividade e mastigabilidade $\left(\mathrm{g} \mathrm{mm}^{-1}\right)$. A análise foi feita em 6 amostras para cada formulação em cada repetição.

\subsection{Estabilidade da emulsão e porcentagem de gordura liberada}

A estabilidade da emulsão foi medida com base no método descrito por Horita et al. (2014); Pesaram-se $25 \mathrm{~g}$ de massa de salsicha (antes do cozimento) em tubos Falcon e centrifugou-se a $2600 \mathrm{rpm} /$ durante $5 \mathrm{~min}$ a $5{ }^{\circ} \mathrm{C}$. Em seguida, as massas foram cozidas em banho a $40{ }^{\circ} \mathrm{C}$ por $15 \mathrm{~min}$, seguidos de cozimento a $70{ }^{\circ} \mathrm{C}$ por $20 \mathrm{~min}$. A massa cozida foi seca com papel toalha e pesada. A estabilidade da emulsão foi calculada como uma percentagem do líquido libertado após o cozimento. O exsudado que permaneceu nos tubos foi coletado e colocado em estufa a $105{ }^{\circ} \mathrm{C}$ durante $16 \mathrm{~h}$. A percentagem de gordura liberada foi calculada a partir da diferença entre a massa do exsudado antes e depois da secagem.

\subsection{Valor de $\mathbf{p H}$}

O pH das amostras foi medido com medidor de pH (HI 99163, Hanna Instruments) específico para produtos cárneos. O eletrodo foi colocado diretamente no produto para aferição dos valores. Três salsichas de cada formulação foram selecionadas. Em cada salsicha foram feitas duas medições.

\subsection{Cor objetiva}

Salsichas foram cortadas longitudinalmente para avaliação de cor interna. Os parâmetros $\mathrm{L} *$ (Luminosidade), a * (vermelho-verde) e b * (amarelo-azul), do sistema CIELAB, foram medidos usando um espectrofotômetro (MiniScan XE, HunterLab, Minolta, Japão) com iluminante D65, $10^{\circ}$ de ângulo de observação e abertura de $30 \mathrm{~mm}$. 


\subsection{Análise sensorial}

A análise sensorial foi realizada no laboratório de análise sensorial da Faculdade de Zootecnia e Engenharia de Alimentos da Universidade de São Paulo (USP), Pirassununga, Brasil. Os testes foram aprovados pelo Comitê de Ética em Pesquisa (Numero do parecer: 2.078.895). Para os testes, foram recrutados 120 consumidores de salsicha entre estudantes e funcionários da universidade. Os consumidores foram servidos com amostras de salsicha (2 cm de comprimento) de forma monádica e seguindo o modo de distribuição em blocos completamente casualizados. Salsichas foram pré-aquecidas em água quente (em ebulição) por $5 \mathrm{~min}$ antes de serem servidas. Cada consumidor avaliou todas as formulações relativamente à aparência, textura, sabor e qualidade global usando uma escala hedônica de 9 pontos $(1=$ Desgostei extremamente, 2 = Desgostei muito, 3 = Desgostei moderadamente, $4=$ Desgostei um pouco, 5 = Não gostei nem desgostei, $6=$ Gostei um pouco, $7=$ Gostei moderadamente, 8 = Gostei muito, $9=$ Gostei extremamente). A intensidade do gosto salgado foi avaliada seguindo a escala just-about-right (escala do ideal -JAR) (1 = Muito menos salgado que o ideal, 2 = Menos salgado que o ideal, 3 = Ideal, 4 = Mais salgado que o ideal, 5 = Muito mais salgado que o ideal) (MEILGAARD; CARR; CIVILLE, 1991).

\subsection{Análise estatística}

Três repetições independentes foram conduzidas (três blocos). Os resultados foram avaliados por análise de variância (ANOVA) e teste de Tukey, a 5\% de significância, utilizando o software SAS (versão 9.4). Para análise sensorial, os tratamentos foram considerados fatores de efeito fixo e os consumidores como fatores de efeito aleatório (STANLEY et al., 2017). 


\section{RESULTADOS E DISCUSSÃO}

\subsection{Composição centesimal, atividade de água e pH}

O conteúdo de cinzas diminuiu $(\mathrm{P}<0,05)$ após reduções de $\mathrm{NaCl}$ em diferentes formulações. Os teores de umidade das salsichas F1 e F1.25 foram maiores $(\mathrm{P}<0,05)$ do que nos tratamentos F1.75 e F2 (Tabela I. 1), provavelmente como resultado da maior quantidade de água adicionada a essas formulações, substituindo a redução de $\mathrm{NaCl}$. Como esperado, não houve diferenças $(\mathrm{P}>0,05)$ nos teores de proteína e gordura entre as formulações, pois as mesmas quantidades de carne e toucinho foram adicionadas a todos os tratamentos.

Os teores de sódio foram reduzidos entre as formulações $(\mathrm{P}<0,05)$ como consequência da redução de $\mathrm{NaCl}$ (Tabela I. 1). Para um alimento ser considerado reduzido em sódio, deve haver pelo menos $25 \%$ a menos desse elemento do que a quantidade em um alimento de referência apropriado (FDA, 2013). Em comparação com F2, as formulações F1 e F1.25 apresentaram 38,83\% e 27,18\% menos sódio. Assim, estas formulações podem ser consideradas como alimentos reduzidos em sódio.

Tabela I. 1 - Composição centesimal em base úmida e concentração de sódio (Na) nas formulações de salsicha com redução de sódio e gordura

\begin{tabular}{lcccccc}
\hline Item & $\mathrm{F} 1$ & $\mathrm{~F} 1.25$ & $\mathrm{~F} 1.50$ & $\mathrm{~F} 1.75$ & $\mathrm{~F} 2$ & $\mathrm{EP}$ \\
\hline Umidade $(\mathrm{g} / 100 \mathrm{~g})$ & $67,76^{\mathrm{A}}$ & $67,25^{\mathrm{A}}$ & $67,03^{\mathrm{AB}}$ & $66,05^{\mathrm{B}}$ & $65,19^{\mathrm{C}}$ & 0,35 \\
Proteina $(\mathrm{g} / 100 \mathrm{~g})$ & $16,67^{\mathrm{A}}$ & $16,36^{\mathrm{A}}$ & $16,07^{\mathrm{A}}$ & $16,40^{\mathrm{A}}$ & $16,30^{\mathrm{A}}$ & 0,36 \\
Lipídios $(\mathrm{g} / 100 \mathrm{~g})$ & $10,04^{\mathrm{A}}$ & $9,69^{\mathrm{A}}$ & $9,96^{\mathrm{A}}$ & $10,10^{\mathrm{A}}$ & $10,30^{\mathrm{A}}$ & 0,35 \\
Cinzas $(\mathrm{g} / 100 \mathrm{~g})$ & $2,12^{\mathrm{D}}$ & $2,54^{\mathrm{C}}$ & $2,88^{\mathrm{B}}$ & $3,13^{\mathrm{B}}$ & $3,51^{\mathrm{A}}$ & 0,35 \\
Sódio $(\mathrm{g} / 100 \mathrm{~g})$ & $0,63^{\mathrm{C}}$ & $0,75^{\mathrm{BC}}$ & $0,83^{\mathrm{B}}$ & $0,88^{\mathrm{B}}$ & $1,03^{\mathrm{A}}$ & 0,07 \\
\hline
\end{tabular}

F1: $1 \% \mathrm{NaCl}, \mathrm{F} 1.25: 1.25 \% \mathrm{NaCl}, \mathrm{F} 1.50: 1.50 \% \mathrm{NaCl}, \mathrm{F} 1.75: 1.75 \% \mathrm{NaCl}, \mathrm{F} 2: 2 \% \mathrm{NaCl}$.

${ }_{\mathrm{ABCD}}$ Letras diferentes na mesma linha indicam diferença significativa entre amostras ao nível de $5 \%$. EP = Erro padrão

$\mathrm{O} \mathrm{NaCl}$ é reconhecido como redutor da atividade de água, por isso atua na preservação de alimentos, reduzindo o crescimento microbiano. Este efeito pode ser observado na Tabela 
2, na qual se percebe redução linear dos valores de atividade de água com aumento na concentração de sal (de 0,98 em F1 para 0,96 em F2) (P <0,05).

Não houve diferença $(\mathrm{P}>0,05)$ no $\mathrm{pH}$ das amostras entre as diferentes formulações. $\mathrm{O} \mathrm{pH}$ das salsichas ficou próximo de 6,0. Resultados semelhantes foram encontrados por Aaslyng, Vestergaard e Koch (2014), Yotsuyanagi et al. (2016) e Stanley et al. (2017), os quais também estudaram a redução de sódio em salsicha.

\subsection{Estabilidade de emulsão}

A redução da concentração de $\mathrm{NaCl}$ nas formulações promoveu diminuição $(\mathrm{P}<0,05)$ na estabilidade da emulsão das massas, ou seja, maior liberação de água e gordura (\%) (Tabela I.2). As funções do sal na matriz cárnea podem explicar esses resultados de várias maneiras. A primeira e mais simples explicação é que o sal aumenta a viscosidade da massa de carne, o que facilita a incorporação de gordura e a formação de um sistema mais estável (O'FLYNN et al., 2014; TERRELL, 1983).

É bem estabelecido que o $\mathrm{NaCl}$ afeta consideravelmente a funcionalidade das proteínas. Quando se difunde nas fibras musculares, o $\mathrm{NaCl}$ promove a liberação de água intracelular, com a consequente liberação de proteínas miofibrilares, vitaminas e minerais. Estas proteínas, extraídas na presença de $\mathrm{NaCl}$ durante a etapa de cominuição, são responsáveis pelas propriedades de retenção de água, emulsificação e capacidade de ligação de gordura, levando à formação de géis estáveis na fase de cocção (DESMOND, 2006; MARCHETTI et al. 2015, WU et al., 2016). Assim, em formulações com uma concentração maior de $\mathrm{NaCl}$, houve uma maior quantidade de proteínas extraídas e uma melhor estabilidade da emulsão, isto é, elevada capacidade de ligação de água e gordura. Da mesma forma, O'Flynn et al. (2014) observaram maior liberação de gordura em produtos cárneos emulsionados e com concentração $\mathrm{NaCl}$ reduzida abaixo de 1,5\%. No presente estudo, F1.50, F1.25 e F1 apresentaram menor estabilidade de emulsão do que a formulação controle (F2). 
Tabela I. 2 Médias das análises realizadas em formulações de salsicha com reduzido teor de gordura e sal $(\mathrm{NaCl})$

\begin{tabular}{|c|c|c|c|c|c|c|}
\hline \multirow[b]{2}{*}{ Variáveis } & \multirow[b]{2}{*}{ F1 } & \multicolumn{5}{|c|}{ Formulações } \\
\hline & & F1.25 & F1.50 & F1.75 & F2 & EP \\
\hline $\mathrm{pH}$ & $5,99^{\mathrm{A}}$ & $6,09^{\mathrm{A}}$ & $6,02^{\mathrm{A}}$ & $5,99^{\mathrm{A}}$ & $5,96^{\mathrm{A}}$ & 0,015 \\
\hline $\mathrm{Aa}$ & $0,98^{\mathrm{A}}$ & $0,98^{\mathrm{A}}$ & $0,98^{\mathrm{AB}}$ & $0,97^{\mathrm{BC}}$ & $0,96^{\mathrm{C}}$ & 0,0019 \\
\hline Estab. (\%) & $75,39^{\mathrm{A}}$ & $85,91^{\mathrm{B}}$ & $90,56^{\mathrm{C}}$ & $92,84^{\mathrm{CD}}$ & $93,90^{\mathrm{D}}$ & 0,77 \\
\hline$\%$ Gordura liberada & $11,11^{\mathrm{A}}$ & $9,14^{\mathrm{B}}$ & $5,61^{\mathrm{C}}$ & $4,24^{\mathrm{CD}}$ & $3,49^{\mathrm{D}}$ & 0,37 \\
\hline Dureza $(\mathrm{N})$ & $27,42^{\mathrm{C}}$ & $42,74^{\mathrm{B}}$ & $52,75^{\mathrm{A}}$ & $54,40^{\mathrm{A}}$ & $44,08^{\mathrm{B}}$ & 1,76 \\
\hline Elasticidade (mm) & $0,83^{\mathrm{AB}}$ & $0,88^{\mathrm{AB}}$ & $0,88^{\mathrm{AB}}$ & $0,89^{\mathrm{A}}$ & $0,81^{\mathrm{B}}$ & 0,018 \\
\hline Coesividade & $0,61^{\mathrm{C}}$ & $0,69^{\mathrm{B}}$ & $0,74^{\mathrm{A}}$ & $0,74^{\mathrm{A}}$ & $0,76^{\mathrm{A}}$ & 0,0068 \\
\hline Mastigabilidade(N.mm) & $13,62^{\mathrm{C}}$ & $26,40^{\mathrm{B}}$ & $34,36^{\mathrm{A}}$ & $36,01^{\mathrm{A}}$ & $27,48^{\mathrm{B}}$ & 1,36 \\
\hline$L^{*}$ & $54,20^{\mathrm{A}}$ & $55,08^{\mathrm{A}}$ & $54,41^{\mathrm{A}}$ & $54,18^{\mathrm{A}}$ & $54,47^{\mathrm{A}}$ & 0,19 \\
\hline$a^{*}$ & $17,68^{\mathrm{A}}$ & $17,91^{\mathrm{A}}$ & $18,40^{\mathrm{A}}$ & $18,34^{\mathrm{A}}$ & $18,43^{\mathrm{A}}$ & 0,10 \\
\hline$b^{*}$ & $13,56^{\mathrm{A}}$ & $13,92^{\mathrm{A}}$ & $13,19^{\mathrm{A}}$ & $12,94^{\mathrm{A}}$ & $12,90^{\mathrm{A}}$ & 0,08 \\
\hline
\end{tabular}

\subsection{Análise de perfil de textura}

Os valores de coesividade aumentaram $(\mathrm{P}<0,05)$ com o aumento da concentração de $\mathrm{NaCl}$. Para os outros parâmetros de TPA (dureza, elasticidade e mastigabilidade), verificou-se um aumento significativo $(\mathrm{P}<0,05)$ e sequencial com o aumento na concentração de $\mathrm{NaCl}$ até 1,75\%, seguido de diminução para F2. O aumento sequencial nos parâmetros de TPA pode estar relacionado com o aumento da solubilidade das proteínas nos produtos conforme a concentração de sal aumentou (BARRETTO et al., 2018). Em produtos cárneos cominuídos, a dureza é fortemente influenciada pela concentração de proteínas na fase aquosa antes do cozimento, que, por sua vez, está relacionada à quantidade de sal adicionada. Da mesma forma, a coesão é um atributo formado na etapa de pré-cozimento e também é uma função 
direta da quantidade de proteína extraída (O'FLYNN et al., 2014). Paralelamente, segundo Ruusunen e Puolanne (2005), o NaCl aumenta a coesividade da emulsão, levando a uma melhor retenção de água e gordura.

A diminuição na dureza, elasticidade e mastigabilidade verificada em F2 em comparação com F1.75 podem ser devidas à uma capacidade desta formulação de reter água e gordura na matriz muito maior do que as outras formulações, isto é, F2 apresentou estabilidade de emulsão muito maior (Tabela I.2). Neste caso as miofibrilas estariam muito mais inchadas, levando à melhor a ligação da água durante a subsequente gelificação na cocção (DOYLE; GLASS, 2010; LOWDER; MIRELES; DEWITT, 2014). A textura em produtos cárneos emulsionados está relacionada à capacidade da emulsão reter água e gordura (YOTSUYANAGI et al., 2016). Quantidades mais elevadas de água e gordura na formulação proporcionam uma textura mais suave aos produtos cárneos emulsionados (ZHAO et al., 2018). McGough et al (2012) também avaliaram a redução de sódio em salsicha através do uso de realçado de sabor e substituição por $\mathrm{KCl}$ (teor de sal na formulação variando de 2,5 a $1,25 \mathrm{~g} / 100 \mathrm{~g}$ ). Entretanto ou autores não reduziram o teor de gordura das formulações (teor final de $25,5 \%$ de gordura). Os autores verificaram que a firmeza, elasticidade e mastigabilidade de todas as formulações avaliadas foram menores que da formulação controle. Isso demonstra o efeito negativo da redução de sal em produtos emulsionados com e sem redução de gordura.

\subsection{Microscopia Eletrônica de Varredura (MEV)}

As micrografias obtidas por MEV revelaram diferentes estruturas para cada uma das formulações estudadas (Figura I.1).

Salsichas F2 mostraram uma rede mais aberta. A porosidade da matriz de salsicha diminuiu progressivamente da formulação F2 para F1, com a última apresentando uma estrutura relativamente mais compacta. Diferenças na microestrutura das emulsões também 
foram observadas por Marchetti et al. (2015), que demonstraram que a substituição do $\mathrm{NaCl}$ por $\mathrm{KCl}$, resultou em uma estrutura menos homogênea. Contrariamente, Horita et al. (2014) relataram um aumento da porosidade com a redução da quantidade de $\mathrm{NaCl}$. Mudanças no comportamento das proteínas durante o aquecimento são devidas aos ingredientes e processos aos quais produtos cominuídos são submetidos. A extração de proteínas é provavelmente a alteração mais crucial, mas, além da carne, a emulsão é formada por outros compostos insolúveis, cuja quantidade e estado influenciam a gelificação (TORNBERG, 2005).

Tahmasebi et al. (2016) mencionaram que poros entre matrizes indicam a presença de cristais de gelo, ou água, que são sublimados durante a preparação da amostra para MEV. A expansão de gordura, água e ar dentro da matriz também leva à formação de uma estrutura esponjosa, característica dos produtos cárneos emulsionados (DELGADO-PANDO et al., 2011). Assim, a partir da formulação F2 até $\mathrm{F} 1$, as salsichas apresentaram quantidades decrescentes de água e gordura na matriz (conforme verificados pelas medidas de estabilidade apresentadas na Tabela I.2), acompanhadas de redução da porosidade, indicando que a água e a gordura foram perdidas durante a fase de cozimento. A baixa capacidade de retenção de água e gordura é uma característica das emulsões com baixa estabilidade, o que corrobora os resultados anteriores explicados na seção "Estabilidade da emulsão". 
Figura I. 1- Imagens de microscopia eletronica de varredura para salsichas com concentrações variáveis de $\mathrm{NaCl}$ na aproximações 50x (A), 100x (B) e 500x (C)

Fonte: Própria autoria
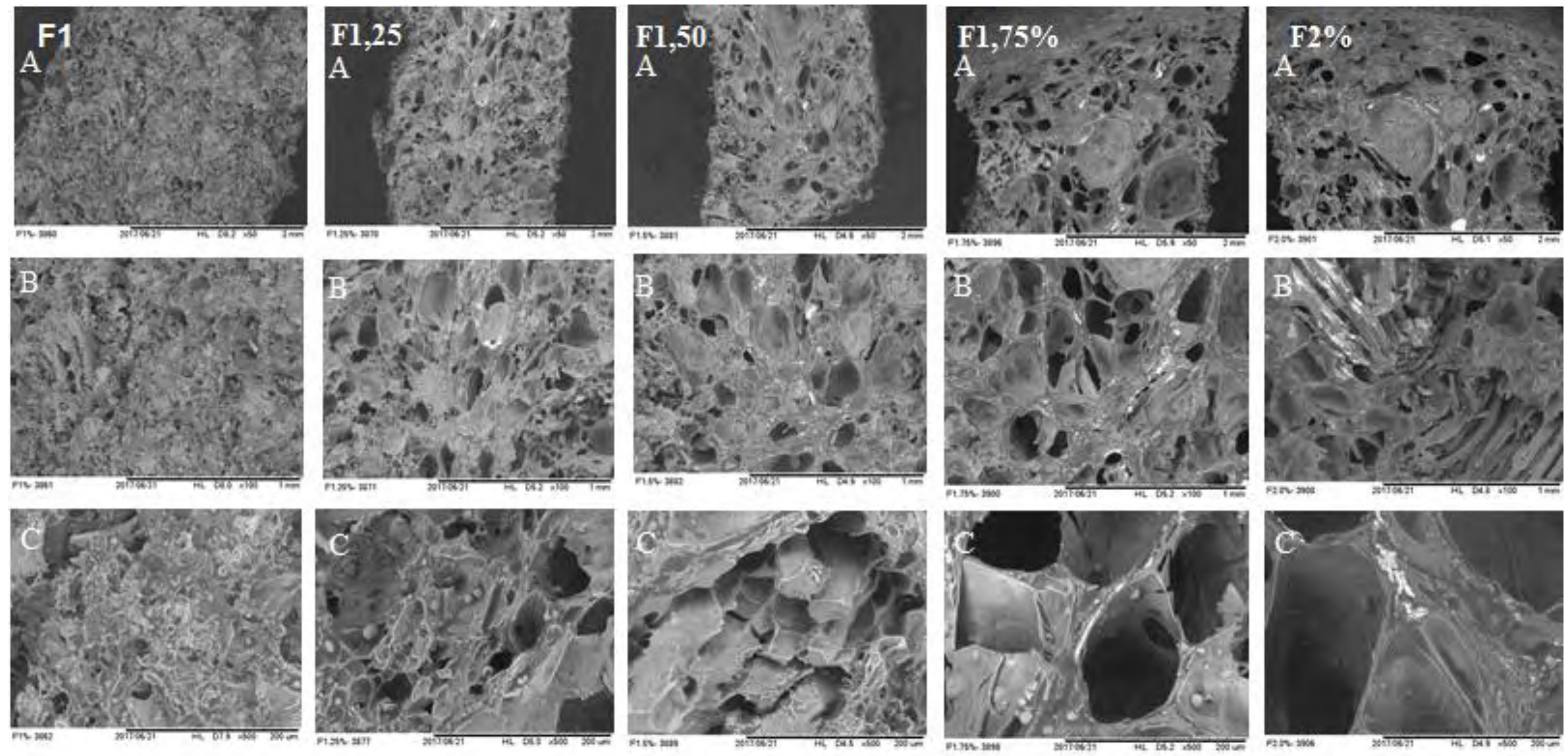


\subsection{Cor objetiva}

Os valores $\mathrm{L} *, \mathrm{a} * \mathrm{e} \mathrm{b} *$ não diferiram $(\mathrm{P}>0,05)$ entre todas as formulações estudadas (Tabela I.2). Marchetti et al. (2015), encontraram valores de a* variando de 16,2 a 18,3 em produtos cárneos emulsionados, próximos aos encontrados neste trabalho. Delgado-Pando et al. (2018) verificaram que a cor instrumental não foi afetada pela redução de sal no presunto e no bacon. Bower et al. (2018) também não encontraram impacto significativo da concentração de sal (de 1 a 2,5\%) em peito de peru ou carne assada fatiada. Em produtos cárneos curados, o nitrito de sódio é o agente responsável pela formação da cor, pois reage com a mioglobina da carne para formar nitrosomioglobina durante o cozimento. A mesma quantidade de nitrito de sódio e carne foi utilizada em todas as formulações, tornando coerentes os resultados da análise de cor.

\subsection{Análise sensorial}

Os consumidores atribuíram notas diferentes $(\mathrm{P}<0,05)$ entre as amostras quanto aos atributos de textura e sabor (Tabela I.3). A aceitação da textura do tratamento F2 (controle) não foi significativamente diferente $(\mathrm{P}>0,05)$ de F1, F1.25 e F1.50, mas foi maior que F1.75, possivelmente refletindo a textura mais macia encontrada para o tratamento F2 em TPA. Em relação ao atributo sabor, as formulações $\mathrm{F} 1$ e F2 receberam as menores pontuações. F1.25, F1.50 e F1.75 não diferiram entre si (P> 0,05) (Tabela 3).

Em relação ao teste com a escala do ideal para gosto salgado, diferenças significativas $(\mathrm{P}<0,05)$ foram evidentes entre todas as formulações. F1, F1.25 e F1.50 estavam mais próximos de "pouco salgado", a formulação F1.75 foi considerada como tendo a intensidade de gosto salgado ideal, embora não tenha diferido estatisticamente de F1.50 e F2. A partir desses resultados podemos afirmar que a percepção da redução de sal pelos consumidores, nas condições aplicadas no presente estudo, inicia-se com a redução de $25 \%$ de $\mathrm{NaCl}$ (de $2 \%$ (F2) 
para $1,5 \%$ (F1.50). No atributo sabor, F1 e F2 receberam notas significativamente menores que F1.50, que teve a melhor nota. F1.25 e F1.75 não diferiram desta formulação. Considerando esses resultados, F1.25 tem a vantagem de permitir uma maior redução de sódio do que F1.50 e F1.75.

Tabela I. 3- Aceitação sensorial e testes JAR para salsichas com teor reduzido de gordura e sal

\begin{tabular}{lllllll}
\hline Atributo & F1 & F1.25 & F1.50 & F1.75 & F2 & EP \\
\hline Aparência & $6,00^{\mathrm{A}}$ & $6,04^{\mathrm{A}}$ & $6,20^{\mathrm{A}}$ & $5,93^{\mathrm{A}}$ & $6,00^{\mathrm{A}}$ & 0,16 \\
Textura & $5,20^{\mathrm{AB}}$ & $5,69^{\mathrm{A}}$ & $5,36^{\mathrm{AB}}$ & $4,87^{\mathrm{B}}$ & $5,42^{\mathrm{A}}$ & 0,17 \\
Sabor & $6,41^{\mathrm{B}}$ & $6,61^{\mathrm{AB}}$ & $6,94^{\mathrm{A}}$ & $6,56^{\mathrm{AB}}$ & $6,40^{\mathrm{B}}$ & 0,15 \\
Qualidade & $5,99^{\mathrm{A}}$ & $6,33^{\mathrm{A}}$ & $6,32^{\mathrm{A}}$ & $6,00^{\mathrm{A}}$ & $6,17^{\mathrm{A}}$ & 0,14 \\
Global & & & & & & \\
JAR & $2,61^{\mathrm{D}}$ & $2,71^{\mathrm{CD}}$ & $2,85^{\mathrm{BC}}$ & $3,01^{\mathrm{AB}}$ & $3,17^{\mathrm{A}}$ & 0,36 \\
\hline
\end{tabular}

F1: $1 \% \mathrm{NaCl}, \mathrm{F} 1.25: 1.25 \% \mathrm{NaCl}, \mathrm{F} 1.50: 1.50 \% \mathrm{NaCl}, \mathrm{F} 1.75: 1.75 \% \mathrm{NaCl}, \mathrm{F} 2: 2 \% \mathrm{NaCl}$.

${ }_{\mathrm{ABCD}}$ Letras diferentes na mesma coluna indicam diferença significativa a $5 \%$ de significância. $\mathrm{EP}=$ Erro padrão

Escala do teste de aceitação: 1 = Desgostei extremamente, $2=$ Desgostei muito, $3=$ Desgostei moderadamente, $4=$ Desgostei um pouco, $5=$ Não gostei nem desgostei, $6=$ Gostei um pouco, 7 = Gostei moderadamente, $8=$ Gostei muito, $9=$ Gostei extremamente

JAR: just-about-right - Escala do ideal: 1 = Muito menos salgado que o ideal, 2 = Menos salgado que o ideal, $3=$ Ideal, $4=$ Mais salgado que o ideal, 5 = Muito mais salgado que o ideal.

Em geral, as pontuações atribuídas pelos consumidores para todos os tratamentos indicaram notas de aceitação entre "Eu não gostei nem desgostei" e "Gostei um pouco". Estas notas relativamente baixas refletem o impacto negativo que a redução de gordura e sal tem nas características sensoriais dos produtos cárneos emulsionados.

Em pesquisa anterior, Aaslyng, Vestergaard e Koch (2014) mostraram que salsichas com níveis de $\mathrm{NaCl}$ reduzidos até $1,74 \%$ não apresentaram alteração sensorial acentuada, enquanto salsichas com reduções além desse valor apresentaram maior maciez, suculência e um invólucro mais duro. Além disso, a redução para 1,23\% alterou o gosto salgado e o sabor dos condimentos em suas amostras. 


\section{CONCLUSÃO}

Nas condições testadas, a redução de 2 a $1 \%$ do $\mathrm{NaCl}$ provocou diversas alterações físicas, químicas e estruturais nas salsichas com baixo teor de lipídios. No entanto, mesmo com essas mudanças, salsichas com redução de até $27,18 \%$ de sódio foram bem aceitas sensorialmente. Assim, pode-se recomendar a produção de salsichas com baixo teor de gordura adicionadas com apenas $1,25 \%$ de $\mathrm{NaCl}$ para obter um produto mais saudável e ainda aceito.

\section{Agradecimentos}

Os autores agradecem à Coordenação de Aperfeiçoamento de Pessoal de Nível Superior (CAPES) pela bolsa de estudos, Código Financeiro 001; à Cryovac por fornecer as embalagens; à New Max Industrial Ltda pelas amostras de condimento para salsicha; e à Viscofan do Brasil pela doação das tripas celulósicas utilizadas neste estudo. Este trabalho foi financiado pela Fundação de Amparo à Pesquisa do Estado de São Paulo (FAPESP) [2015 / 12429-7]. O autor Marco Antonio Trindade é membro da rede MARCARNE, fundada pela CYTED (ref. 116RT0503). 


\section{REFERÊNCIAS}

AASLYNG, Margit Dall; VESTERGAARD, Christian; KOCH, Anette Granly. The effect of salt reduction on sensory quality and microbial growth in hotdog sausages, bacon, ham and salami. Meat Science, v. 96, n. 1, p. 47-55, 2014.

BARRETTO, Tiago Luis et al. Improving sensory acceptance and physicochemical properties by ultrasound application to restructured cooked ham with salt $(\mathrm{NaCl})$ reduction. Meat science, v. 145, p. 55-62, 2018.

BOWER, Chad G. et al. The effect of salt reduction on the microbial community structure and quality characteristics of sliced roast beef and turkey breast. LWT, v. 90, p. 583-591, 2018.

CONROY, Paula M. et al. Impact on the physical and sensory properties of salt-and fatreduced traditional Irish breakfast sausages on various age cohorts acceptance. Meat science, v. 143, p. 190-198, 2018.

CUNNIFF, Patricia (Ed.). Official methods of analysis of AOAC international. (16th ed.). Arlington, VA: AOAC International. 1998.

DELGADO-PANDO, Gonzalo et al. Low-fat frankfurters formulated with a healthier lipid combination as functional ingredient: Microstructure, lipid oxidation, nitrite content, microbiological changes and biogenic amine formation. Meat Science, v. 89, n. 1, p. 65-71, 2011.

DELGADO-PANDO, Gonzalo et al. Salt content and minimum acceptable levels in wholemuscle cured meat products. Meat science, v. 139, p. 179-186, 2018.

DESMOND, Eoin. Reducing salt: A challenge for the meat industry. Meat science, v. 74, $\mathrm{n}$. 1, p. 188-196, 2006.

DOYLE, Marjorie Ellin; GLASS, Kathleen A. Sodium reduction and its effect on food safety, food quality, and human health. Comprehensive reviews in food science and food safety, $v$. 9, n. 1, p. 44-56, 2010.

FDA. Guidance for Industry: A Food Labeling Guide 9- Appendix A: Definitions of Nutrient Content Claims. 2013 Disponível em <

https://www.fda.gov/Food/GuidanceRegulation/GuidanceDocumentsRegulatoryInformation/ LabelingNutrition/ucm064911.htm> Acesso em 30 jul 2017.

HAGA, Seiichi; OHASHI, Tomio. Heat-induced gelation of a mixture of myosin B and soybean protein. Agricultural and Biological Chemistry, v. 48, n. 4, p. 1001-1007, 1984.

HORITA, C. N. et al. Textural, microstructural and sensory properties of reduced sodium frankfurter sausages containing mechanically deboned poultry meat and blends of chloride salts. Food research international, v. 66, p. 29-35, 2014. 
KEENAN, Derek F. et al. Investigating the influence of inulin as a fat substitute in comminuted products using rheology, calorimetric and microscopy techniques. Food Structure, v. 2, n. 1-2, p. 1-13, 2014.

KILCAST, David; ANGUS, Fiona (Ed.). Reducing salt in foods: Practical strategies. Elsevier, 2007.

KOWALCZEWSKI, Przemysław Łukasz et al. Finely comminuted frankfurters fortified with potato juice-Quality and structure. Journal of Food Engineering, v. 167, p. 183-188, 2015.

LARANJO, Marta et al. Characterisation of "Catalão" and "Salsichão" Portuguese traditional sausages with salt reduction. Meat science, v. 116, p. 34-42, 2016.

LOWDER, Austin C.; MIRELES DEWITT, Christina A. Impact of high pressure processing on the functional aspects of beef muscle injected with salt and/or sodium phosphates. Journal of food processing and preservation, v. 38, n. 4, p. 1840-1848, 2014.

MARCHETTI, Lucas et al. Sodium-reduced lean sausages with fish oil optimized by a mixture design approach. Meat science, v. 104, p. 67-77, 2015.

MCGOUGH, Megan M. et al. Reducing sodium levels in frankfurters using a natural flavor enhancer. Meat science, v. 91, n. 2, p. 185-194, 2012.

MEILGAARD, Morten C.; CARR, B. Thomas; CIVILLE, Gail Vance. Sensory evaluation techniques. CRC press, 1999.

MORA-GALLEGO, Héctor et al. Effect of reducing and replacing pork fat on the physicochemical, instrumental and sensory characteristics throughout storage time of small caliber non-acid fermented sausages with reduced sodium content. Meat science, v. 97, n. 1, p. 62-68, 2014.

O'FLYNN, Claire C. et al. The application of high-pressure treatment in the reduction of salt levels in reduced-phosphate breakfast sausages. Meat science, v. 96, n. 3, p. 1266-1274, 2014.

PUOLANNE, Eero J.; RUUSUNEN, Marita H.; VAINIONPÄÄ, Jukka I. Combined effects of $\mathrm{NaCl}$ and raw meat $\mathrm{pH}$ on water-holding in cooked sausage with and without added phosphate. Meat Science, v. 58, n. 1, p. 1-7, 2001.

RUUSUNEN, Marita; PUOLANNE, Eero. Reducing sodium intake from meat products. Meat science, v. 70, n. 3, p. 531-541, 2005.

SOUSA, Samara C. et al. Quality parameters of frankfurter-type sausages with partial replacement of fat by hydrolyzed collagen. LWT-Food Science and Technology, v. 76, p. 320-325, 2017.

STANLEY, Regan E.; BOWER, Chad G.; SULLIVAN, Gary A. Influence of sodium chloride reduction and replacement with potassium chloride based salts on the sensory and physicochemical characteristics of pork sausage patties. Meat science, v. 133, p. 36-42, 2017. 
TAHMASEBI, Maryam et al. Manufacturing the novel sausages with reduced quantity of meat and fat: The product development, formulation optimization, emulsion stability and textural characterization. LWT-Food Science and Technology, v. 68, p. 76-84, 2016.

TAMM, Alina et al. Salt $(\mathrm{NaCl})$ reduction in cooked ham by a combined approach of high pressure treatment and the salt replacer $\mathrm{KCl}$. Innovative food science \& emerging technologies, v. 36, p. 294-302, 2016.

TERRELL, R. N. Reducing the sodium content of processed meats. Food Technology (Usa), 1983.

TORNBERG, Eva. Effects of heat on meat proteins-Implications on structure and quality of meat products. Meat science, v. 70, n. 3, p. 493-508, 2005.

WU, Lijun et al. Effects of cations on the "salt in" of myofibrillar proteins. Food Hydrocolloids, v. 58, p. 179-183, 2016.

YOTSUYANAGI, Suzana E. et al. Technological, sensory and microbiological impacts of sodium reduction in frankfurters. Meat science, v. 115, p. 50-59, 2016.

YOUSSEF, M. K.; BARBUT, S. Fat reduction in comminuted meat products-effects of beef fat, regular and pre-emulsified canola oil. Meat Science, v. 87, n. 4, p. 356-360, 2011.

ZHAO, Yinyu et al. Effect of regenerated cellulose fiber on the physicochemical properties and sensory characteristics of fat-reduced emulsified sausage. LWT, v. 97, p. 157-163, 2018. 


\section{CAPÍTULO II - UTILIZAÇÃo DE RADIAÇÃo COM RAIOS GAMA PARA AUMENTAR A VIDA ÚTIL DE SALSICHA COM REDUÇÃO DE SAL}

Artigo: USE OF GAMMA RAY RADIATION TO INCREASE SHELF LIFE OF SALT REDUCED HOT DOG SAUSAGES

Isabela Rodrigues, Aline Baldini, Manoela Pires, Julliane Barros, Raul Fregonesi, César Gonçalves de Lima, Marco Antonio Trindade 


\section{RESUMO}

O objetivo deste estudo foi avaliar a eficiência da irradiação com raios gama (1,5, 3,0 e 4,5 kGy) na segurança microbiológica e vida útil de salsichas com redução de sódio e gordura. Os efeitos dessa tecnologia nos parâmetros de qualidade (cor, oxidação lipídica, textura e aceitação sensorial) também foram estudados. Os resultados mostraram que a irradiação teve um efeito significativo na redução da cor vermelha (a*) das salsichas. Níveis mais altos de oxidação lipídica também foram observados no tempo inicial de armazenamento (variando de 0,5 a 1,34 $\mathrm{mg}$ de malonaldeído / $\mathrm{kg}$ de amostra) quando doses mais altas foram aplicadas, no entanto, estes níveis diminuíram devido ao fim do oxigênio residual presente inicialmente nas embalagens e à degradação dos compostos de TBARS já gerados. A aceitação sensorial não foi prejudicada por doses de radiação mais altas. Um efeito significativo e dependente da dose foi observado na redução da carga microbiana. A irradiação em uma dose mínima de 1,5 kGy promoveu redução de até 6 ciclos logarítmicos para bactérias lácticas. A aplicação de 1,5 kGy é, portanto, eficaz para garantir a segurança microbiológica do produto sem alterar sua qualidade.

Palavras-chave: Oxidação lipídica, microbiologia, avaliação sensorial, redução de sódio, radiação. 


\section{INTRODUÇÃO}

A irradiação de alimentos consiste em submeter produtos alimentícios à uma fonte de radiação ionizante, a fim de controlar patógenos, reduzir a carga de microrganismos deteriorantes, a infestação de insetos, inibir a germinação de plantas e prolongar a vida útil de produtos perecíveis (LBERTY et al., 2013). A irradiação é conhecida por ser a tecnologia mais eficaz para a esterilização de alimentos e pode fornecer produtos alimentícios para usos específicos, incluindo aqueles destinados a missões espaciais, militares, idosos e pacientes imunocomprometidos (YUN et al., 2012).

O principal objetivo da irradiação de alimentos é a destruição de microrganismos, aumentando assim a vida útil dos produtos (HARDER; ARTHUR; ARTHUR, 2016). A inativação de microrganismos indesejáveis nos alimentos ocorre pelas alterações químicas causadas pela radiação no microrganismo. Tais mudanças são causadas pela quebra de ligações químicas, que geralmente são do tipo covalente nos alimentos. Além disso, a irradiação leva à formação de radicais hidroxila $(\bullet \mathrm{OH})$, que reagem com o DNA dos microrganismos causando perda de sua capacidade reprodutiva (MOY, 2005).

Essas características tornam a irradiação uma tecnologia muito útil para prolongar a vida útil de alimentos mais propensos à deterioração. Este é o caso, por exemplo, de alimentos com redução de sal. $\mathrm{O}$ papel antimicrobiano do sal $(\mathrm{NaCl})$ está relacionado à sua capacidade de reduzir a atividade da água, danificar a membrana semipermeável das bactérias, limitar a solubilidade do oxigênio, afetar as atividades das enzimas celulares ou forçar as células a gastar energia para excluir íons de sódio (INGLUGLIA et al., 2017). Assim, a redução do sal pode aumentar a perecibilidade dos produtos.

No entanto, a destruição de microrganismos não é a única consequência da aplicação de raios gama. O radical hidroxila também pode reagir com outras moléculas de alimentos, 
como vitaminas, gordura e pigmentos, causando perda de valor nutricional, oxidação lipídica e perda de cor (YU et al., 2016). Portanto, o uso desta tecnologia deve ser cuidadosamente estudado antes da aplicação em cada produto específico para garantir a segurança e a qualidade dos alimentos.

Em 1981, a Organização Mundial da Saúde (OMS) atestou a segurança do uso da radiação nos alimentos, afirmando que o uso de uma dose média de até 10 kGy em alimentos não apresenta riscos toxicológicos e não introduz mudanças nutricionais ou microbiológicas especiais (BREWER, 2009).

Embora seja uma tecnologia segura para utilização, o processo de irradiação pode causar algumas alterações sensoriais. Especificamente em produtos cárneos, a principal causa de perda da qualidade sensorial é a oxidação lipídica (TRINDADE et al., 2009). De acordo com Ham et al. (2017), a dose e a fonte de radiação (raios X, raios gama e feixe de elétrons) aumentam a oxidação lipídica em produtos cárneos de diferentes formas. No caso dos hambúrgueres, os raios gama levaram a valores mais elevados de TBARS, enquanto que em salsichas suínas, os raios X foram responsáveis por níveis mais elevados de oxidação. Harder, Arthur e Arthur (2016) explicaram que a irradiação pode acelerar reações de auto-oxidação lipídica pelas seguintes razões: formação de radicais livres, que se combinam com hidroperóxidos; quebra de hidroperóxidos, permitindo a ação de diversos produtos de decomposição; e destruição de compostos antioxidantes. Em relação ao aroma, compostos de enxofre são conhecidos como os principais componentes na geração de odor de irradiação. No entanto, este odor varia muito dependendo da composição dos compostos voláteis presentes nas amostras (FENG et al., 2017).

Devido a essas mudanças, a combinação de irradiação com outros métodos de conservação foi estudada. A irradiação em combinação com a atmosfera modificada, por exemplo, veio quase como consequência da necessidade de estudar embalagens para produtos 
irradiados (EHLERMANN, 2016). A combinação de compostos antimicrobianos com baixas doses de radiação (DUSSAULT; BENOIT; LACROIX, 2012), ou a irradiação da carne congelada antes do processamento de um produto cárneo (CHOULIARA et al., 2006), o efeito da marinação juntamente com a irradiação gama (FADHEL et al., 2016), o uso de embalagem a vácuo e refrigeração (FREGONESI et al., 2014) e a combinação de irradiação com antioxidantes (HWANG et al., 2015; LIM et al., 2008) são exemplos de processos que foram investigados.

O objetivo deste estudo foi avaliar a eficácia da irradiação com diferentes doses de raios gama na inativação de microrganismos em salsichas com reduzidos teores de sódio e gordura embaladas a vácuo, bem como seu impacto na estabilidade física e química e na aceitação sensorial do produto.

\section{MATERIAIS E MÉTODOS}

\subsection{Preparação de salsichas}

As formulações das salsichas estudadas neste trabalho estão descritas na Tabela II.1. A formulação F2 corresponde à salsicha controle (sem redução de sódio), a formulação F1.25 corresponde à salsicha com redução de sódio $(27,18 \%$ de redução) e teor de gordura de aproximadamente $10 \mathrm{~g} / 100 \mathrm{~g}$. Para o processamento, os ingredientes foram pesados separadamente e homogeneizados em cutter (Trademark Tecmafrig, São Paulo, Brasil) na seguinte ordem: A carne (Dianteiro bovino - Peixinho) e os sais foram inicialmente triturados por 1 min. Em seguida, o toucinho e metade do gelo foram adicionados, seguido da homogeneização por mais 1 minuto. O gelo restante foi adicionado e a mistura continuou por mais alguns minutos até que toda a gordura estivesse incorporada. Finalmente, a fécula de mandioca foi adicionada e misturada por mais alguns minutos até que uma massa homogênea fosse obtida. Durante todo o processo a temperatura foi mantida abaixo de $14{ }^{\circ} \mathrm{C}$. A massa foi 
embutida em tripas celulósicas (Viscofan do Brasil, São Paulo, Brasil) com o auxílio de embutideira pneumático (V25 Sirman). As salsichas foram cozidas em estufa (SL 218 Arprotec, Valinhos, Brasil) a $60{ }^{\circ} \mathrm{C}$ por $30 \mathrm{~min}$ (primeiro com ar seco e após 15 min de vapor), depois $70{ }^{\circ} \mathrm{C}$ por 40 min e finalmente $80{ }^{\circ} \mathrm{C}$ até atingir temperatura interna de $72{ }^{\circ} \mathrm{C}$. As salsichas foram então resfriadas com água corrente e armazenadas em câmara fria $\left(4{ }^{\circ} \mathrm{C}\right)$ por 16 horas. A tripa foi removida e as salsichas foram embaladas a vácuo e armazenadas sob refrigeração $\left(4^{\circ} \mathrm{C}\right)$ durante 60 dias para análise.

O processamento e as análises posteriores ocorreram na Faculdade de Zootecnia e Engenharia de Alimentos - USP em Pirassununga - São Paulo, Brasil.

Tabela II. 1 Formulações utilizadas no preparo de salsicha com e sem redução de sódio

\begin{tabular}{lcc}
\hline Ingredientes & F1.25 $(\%)$ & F2 $(\%)$ \\
\hline Dianteiro bovino (Supraspinatus) & 60,0 & 60,0 \\
Toucinho & 9,5 & 9,5 \\
Fécula de mandioca (Yoki, Brazil) & 2,0 & 2,0 \\
Sal (NaCl)(Cisne, Brazil) & 1,25 & 2,0 \\
Nitrito de sódio (Cori, Brazil) & 0,015 & 0,015 \\
Eritorbato de sódio (Cori, Brazil) & 0,05 & 0,05 \\
Tripolifosfato de sódio (Cori, Brazil) & 0,25 & 0,25 \\
Condimento (New max, Brazil) & 0,5 & 0,5 \\
Corante carmim de cochonilha & 0,05 & 0,05 \\
\hline Água/Gelo & 26,39 & 25,64 \\
\hline Total & $\mathbf{1 0 0}$ & $\mathbf{1 0 0}$ \\
\hline
\end{tabular}

F1.25: com redução de sódio/F2: sem redução de sódio

\subsection{Processo de irradiação}

Após o processamento e embalagem, as salsichas foram irradiadas com três doses diferentes: 1,5, 3,0 e 4,5 kGy, designadas como os tratamentos I1.5, I3.0 e I4.5, respectivamente. Os tratamentos foram analisados durante 60 dias de armazenamento refrigerado em conjunto com duas formulações controle: salsichas não irradiadas com redução 
de sódio (F0) e salsichas sem redução de sódio e não irradiadas (F2). O crescimento microbiano foi acompanhado durante 75 dias.

O processo de irradiação foi realizado no dia seguinte ao processamento através do irradiador Cobalto-60, localizado no Instituto de Pesquisas Energéticas Nucleares (IPEN), em São Paulo, Brasil, a uma taxa de $5 \mathrm{kGy} \cdot \mathrm{h}^{-1} \mathrm{em}$ modo estático. Todo o estudo foi repetido três vezes.

\subsection{Análises físicas e químicas}

As salsichas foram testadas quanto à cor objetiva, pH, oxidação lipídica, textura, aceitação sensorial e análises microbiológicas (Salmonela sp, coliformes termotolerantes, estafilococos Coagulase-positiva, Clostridios sulfito redutores, psicrotróficos anaeróbios e bactérias lácticas). Descrições dos métodos são as seguintes:

\subsubsection{Cor Instrumental}

Para avaliação da cor interna as amostras foram cortadas longitudinalmente. Foram avaliados os parâmetros $\mathrm{L} *$ (luminosidade), a * (verde-vermelho), b * (amarelo-azul) do sistema CIELAB com um espectrofotômetro (marca MiniScan XE, HunterLab) usando iluminante D65 com ângulo de observação de $10^{\circ}$.

\subsubsection{Valor do $\mathrm{pH}$}

Utilizou-se um medidor de pH (Modelo HI 99163, Mark HANNA) com eletrodo combinado para leitura com perfuração da amostra; Dois pontos de cada salsicha foram lidos em três salsichas por tratamento (6 repetições).

\subsubsection{Oxidação Lipídica}

Para a análise da oxidação lipídica, o índice TBARS foi avaliado por meio da metodologia descrita por Vincke (1970). As salsichas foram trituradas em um 
multiprocessador por 2 minutos. Em seguida, $5 \mathrm{~g}$ foram pesados em tubos falcon e adicionados com $25 \mathrm{~mL}$ de ácido tricloroacético $(7,5 \mathrm{~g} / 100 \mathrm{~mL})$. Esta mistura foi homogeneizada em ultra turrex (Turratec TE-102, TECNAL, Brasil) por 2 minutos e filtrada. Em seguida, adicionou-se $5 \mathrm{~mL}$ da amostra filtrada em tubos de ensaio com $5 \mathrm{~mL}$ de ácido tiobarbitúrico $(0,02 \mathrm{M})$. As amostras foram colocadas em banho térmico (Marconi, Brasil) a $98{ }^{\circ} \mathrm{C} / 40$ min. A concentração de substâncias reativas ao ácido tiobarbitúrico (TBARS) foi calculada após a leitura das amostras em espectrofotômetro (Biospectro, SP -22, Brasil) (538 nm). A curva de calibração foi construída usando solução de tetraetoxipropano. Os resultados foram expressos em $\mathrm{mg}$ de malonaldeído / $\mathrm{kg}$ de amostra.

\subsubsection{Análise de perfil de textura (TPA)}

O perfil de textura instrumental foi realizado utilizando o TAXT2i Texture Analyzer (Stable Micro Systems, Godalming, Reino Unido). As salsichas foram cortadas em cilindros de $2 \mathrm{~cm}$ de altura e comprimidas duas vezes a $50 \%$ de sua altura (deformação) com o probe SMS P35, a velocidade de 2,0 mm / s e tempo de $2 \mathrm{~s}$ entre as compressões. Os parâmetros estudados foram: dureza (g), elasticidade (adimensional) e mastigabilidade (g.mm). A análise foi realizada em 8 amostras ( 8 repetições) para cada tratamento.

\subsection{Análises microbiológicas}

Contagens de bactérias ácido lácticas (LAB), bactérias psicrotróficas anaeróbias, coliformes termotolerantes, Estafilococos coagulase-positivos e Clostrídios sulfito redutores, bem como a presença de Salmonela foram avaliados durante os 75 dias de estocagem refrigerada. Para LAB, foi utilizado o ágar Lactobacilli DeMan, Rogosa e Sharpe (MRS) (Acumedia, Neogen Corporation); as placas foram incubadas a $37{ }^{\circ} \mathrm{C} / 48 \mathrm{~h}$. Para psicrotróficos anaeróbios, foi utilizado o ágar padrão de contagem, as placas foram incubadas a $21{ }^{\circ} \mathrm{C} / 72 \mathrm{~h}$. A anaerobiose foi mantida colocando-se as placas em uma jarra (Probac do Brasil, São Paulo, 
Brasil) com um gerador de anaerobiose (Anaerobac, Probac do Brasil, São Paulo, Brasil). Para coliformes termotolerantes, placas de contagem de coliformes (6410, PetrifilmTM 3M Health Care, St. Paul, MN, EUA) foram utilizadas. As placas foram incubadas a $45{ }^{\circ} \mathrm{C} / 24 \mathrm{~h}$. Os estafilococos coagulase positivos foram contados usando placas de contagem STX (6490, PetrifilmTM 3M Health Care, St.Paul, MN, EUA) e $24 \mathrm{~h}$ de incubação a $37{ }^{\circ} \mathrm{C}$. Para Clostrídios sulfito redutoreso, foi utilizado o ágar tripto sulfito cicloerossina (TSC) (Sigma); as placas foram incubadas a $45{ }^{\circ} \mathrm{C} / 24 \mathrm{~h}$ em condições de anaerobiose. Para a análise de Salmonela, foi realizado o procedimento prévio de enriquecimento diluindo $25 \mathrm{~g}$ da amostra em $225 \mathrm{ml}$ de água peptonada tamponada (Merck KGaA, Darmstadt, Alemanha) seguido de incubação a $37{ }^{\circ} \mathrm{C} / 24 \mathrm{~h}$ antes de realizar as leituras usando o sistema BAX DuPont Qualicon. O kit Bax para Salmonela (DuPont Nutrition and Health, Wilmington, EUA) foi usado para determinar a presença de Salmonela por reação em cadeia da polimerase (PCR).

\subsection{Avaliações sensoriais}

O teste de aceitação foi realizado utilizando a escala hedônica de nove pontos $(1=$ Desgostei extremamente, 2 = Desgostei muito, 3 = Desgostei moderadamente, 4 = Desgostei um pouco, 5 = Não gostei nem desgostei, $6=$ Gostei um pouco, 7 = Gostei moderadamente, 8 = Gostei muito, 9 = Gostei extremamente) para os atributos aparência, aroma, textura, sabor e qualidade geral (MEILGAARD; CIVILLE; CARR 1991). Para o teste as salsichas foram cozidas por 5 minutos, cortadas em pedaços de $2 \mathrm{~cm}$ e servidas monadicamente a 119 consumidores. Cada consumidor avaliou todos os cinco tratamentos, que foram servidos em blocos completamente casualizados. A análise sensorial foi realizada na Faculdade de Zootecnia e Engenharia de Alimentos da Universidade de São Paulo, Pirassununga, Brasil. Os testes foram aprovados pelo Comitê de Ética em Pesquisa local (Numero do parecer: 2.078.895). 


\subsection{Análise estatística}

Três repetições independentes foram realizadas. Para fins estatísticos, cada repetição foi considerada um bloco. Os resultados foram avaliados por análise de variância (ANOVA) e teste de Tukey, a 5\% de significância. A análise dos dados foi realizada utilizado o procedimento plot mix (SAS 2014. SAS / STAT® 13.2). Para análise sensorial, os tratamentos foram considerados fatores de efeito fixo e os consumidores como fatores de efeito aleatório (STANLEY et al., 2017).

\section{RESULTADOS E DISCUSSÃO}

\subsection{Oxidação Lipídica}

Salsichas irradiadas apresentaram maiores níveis de oxidação no início do período de armazenamento (Tabela II.2) do que as não irradiadas. O efeito da irradiação na aceleração da oxidação lipídica tem sido relatado em vários estudos e está relacionado à geração de radicais hidroxilas, que catalisam reações de oxidação (FENG et al., 2017; KIM et al., 2012; PARK et al., 2010). O dano à estrutura muscular por radicais e a exposição de ácidos graxos ao oxigênio também têm sido relacionados ao aumento de TBARS para produtos irradiados (CHENG et al., 2011). Geralmente a irradiação causa tanto a indução da oxidação quanto seu progresso durante o tempo de armazenamento; no entanto, esse comportamento pode variar dependendo das características da carne e de seus produtos, como conteúdo lipídico, composição de ácidos graxos, antioxidantes, pigmentos heme e iniciadores de oxidação (CAVA et al., 2009).

Na segunda semana de análise, observou-se uma queda significativa nos valores de TBARS e, a partir daí, os valores permaneceram abaixo do nível máximo aceitável (1 MDA.Kg-1) que poderia causar percepção de rancidez (AMARAL et al., 2000; DAS et al., 
2008). Neste estudo, os maiores valores de TBARS no tempo inicial para amostras irradiadas podem ser atribuídos ao maior potencial de oxidação da energia de radiação neste período, o que resulta na formação de uma grande quantidade de radicais livres na salsicha (CHOULIARA et al., 2006). Após este período, a taxa de oxidação lipídica diminuiu e os compostos formados diminuíram como resultado da interação de produtos reativos com o TBA com outros constituintes do tecido muscular ou com a destruição do malonaldeído pela microflora sobrevivente (CHENG et al., 2011).

\subsection{Valor de $\mathbf{p H}$}

As salsichas irradiadas mostraram uma pequena alteração de $\mathrm{pH}$ no tempo inicial de armazenamento (Tabela II.2). A redução do pH devido à irradiação também foi observada por Ham et al. (2017). No entanto, neste caso, a redução ocorreu em uma escala muito pequena, o que não alteraria as características de qualidade dos produtos.

Durante os 60 dias de armazenamento, uma redução significativa do pH foi observada para as amostras não irradiadas (F0). Para o tratamento com F2, uma queda significativa no $\mathrm{pH}$ foi observada no final do período de armazenamento. A queda de $\mathrm{pH}$ durante o período de armazenamento pode ser atribuída à geração de ácido lático durante o crescimento de bactérias lácticas (LARANJO et al., 2016). Esses resultados indicam que salsichas com baixo nível de sal (em primeiro lugar), ou salsichas sem redução de sal mas que não foram irradiadas apresentaram maior geração de ácido lático, devido ao maior crescimento de bactérias lácticas. Sabe-se que a irradiação e a adição de sal $(\mathrm{NaCl})$ atuam no controle do crescimento bacteriano, o que contribuiu para diminuir a geração de ácido láctico e, consequentemente, menor acidez nas amostras irradiadas e sem redução de sódio (FADHEL et al, 2016). 
Tabela II. 2- Concentração de substâncias reativas ao ácido tiobarbitúrico (Tbars) e variação dos valores de $\mathrm{pH}$ durante 60 dias de armazenamento refrigerado para salsichas com 1,25 ou $2 \%$ de $\mathrm{NaCl}$ submetidas a diferentes doses de radiação

\begin{tabular}{|c|c|c|c|c|c|c|c|}
\hline & Tempo & Fo & I1.5 & I3.0 & I4.5 & F2\% & $\begin{array}{l}\text { Erro } \\
\text { Padrão }\end{array}$ \\
\hline \multirow{5}{*}{ 菖 } & Inicial & $0,68^{\mathrm{bABC}}$ & $0,79^{\mathrm{abA}}$ & $1,08^{\mathrm{abA}}$ & $1,35^{\mathrm{aA}}$ & $0,52^{\mathrm{bA}}$ & 0,07 \\
\hline & 15 dias & $0,39^{\mathrm{cC}}$ & $0,53^{\mathrm{bA}}$ & $0,69^{\mathrm{aAB}}$ & $0,69^{\mathrm{aB}}$ & $0,30^{\mathrm{cA}}$ & 0,01 \\
\hline & 30 dias & $0,73^{\mathrm{aAB}}$ & $0,53^{\mathrm{abA}}$ & $0,67^{\mathrm{ab} A B C}$ & $0,71^{\mathrm{abB}}$ & $0,42^{\mathrm{bA}}$ & 0,03 \\
\hline & 45 dias & $0,54^{\mathrm{aBC}}$ & $0,49^{\mathrm{aA}}$ & $0,48^{\mathrm{aC}}$ & $0,47^{\mathrm{aB}}$ & $0,24^{\mathrm{bA}}$ & 0,03 \\
\hline & 60 dias & $0,52^{\mathrm{abBC}}$ & $0,55^{\mathrm{abA}}$ & $0,63^{\mathrm{aABC}}$ & $0,50^{\mathrm{abB}}$ & $0,32^{\mathrm{bA}}$ & 0,03 \\
\hline \multirow{5}{*}{ 跣 } & Inicial & $6,18^{\mathrm{aA}}$ & $6,03^{\mathrm{bA}}$ & $6,03^{\mathrm{bBC}}$ & $6,13^{\mathrm{abA}}$ & $6,10^{\mathrm{abA}}$ & 0,02 \\
\hline & 15 dias & $5,76^{\mathrm{bC}}$ & $5,97^{\mathrm{aA}}$ & $6,00^{\mathrm{aBC}}$ & $6,01^{\mathrm{aA}}$ & $6,01^{\mathrm{aA}}$ & 0,02 \\
\hline & 30 dias & $5,64^{\mathrm{bC}}$ & $6,01^{\mathrm{aA}}$ & $6,06^{\mathrm{aAB}}$ & $6,10^{\mathrm{aA}}$ & $6,07^{\mathrm{aA}}$ & 0,01 \\
\hline & 45 dias & $5,59^{\mathrm{aC}}$ & $5,92^{\mathrm{aA}}$ & $5,80^{\mathrm{aC}}$ & $5,92^{\mathrm{aA}}$ & $5,92^{\mathrm{aA}}$ & 0,04 \\
\hline & 60 dias & $5,64^{\mathrm{bC}}$ & $6,02^{\mathrm{aA}}$ & $6,02^{\mathrm{aBC}}$ & $6,10^{\mathrm{aA}}$ & $6,05^{\mathrm{aA}}$ & 0,02 \\
\hline
\end{tabular}

abc - Diferentes letras minúsculas na mesma linha indicam que as amostras apresentaram diferença significativa entre os tratamentos no mesmo tempo de estudo $(\mathrm{P} \leq 0,05)$. ${ }^{\mathrm{ABC}}$ - Diferentes letras maiúsculas na mesma coluna indicam que as amostras apresentaram diferença significativa ao longo do o tempo de estudo $(\mathrm{P} \leq 0,05)$.

Os valores de pH e TBARS são médias de 6 amostras em três repetições (18 medidas) / TBARS: Concentração de substâncias reativas ao ácido tiobarbitúrico (mg TBA / $\mathrm{kg}$ de amostra)

F0: Salsicha com 1,25\% NaCl sem irradiação / I1.5: Salsicha com 1,25\% NaCl irradiada com uma dose de 1,5 kGy / I3.0: Salsicha com 1,25\% NaCl irradiada com 3,0 kGy / I4.5: Salsicha com 1,25\% NaCl irradiada com uma dose de 4,5 kGy / F2: salsicha com $2 \%$ de $\mathrm{NaCl}$, sem irradiar.

\subsection{Cor objetiva}

O efeito do tempo de armazenamento e da radiação na cor da salsicha pode ser visto na Figura II.1 (L - Luminosidade, $\mathrm{a}^{*}$ - vermelho e $\mathrm{b}^{*}$ - amarelo). Embora tenhamos observado valores ligeiramente inferiores na curva F2, a análise estatística não encontrou variação significativa $(\mathrm{P}>0,05)$ na luminosidade das amostras ao longo do tempo ou entre os tratamentos. Diferentemente, a aplicação de 1,5, 3,0 ou 4,5 kGy causou redução $(\mathrm{P}<0,05)$ na intensidade da cor vermelha das salsichas. Essa diferença foi mantida até o trigésimo dia de 
armazenamento, quando os valores de a $*$ entre os tratamentos começaram a se aproximar. Deve-se notar que os valores de a $*$ para as amostras irradiadas diferiram (foram menores) do tratamento F0 não irradiado, mas foram semelhantes aos de F2. Quanto ao parâmetro b *, observou-se que o tratamento F2 apresentou valores menores que os demais tratamentos.

Segundo Brewer (2004) a irradiação da carne leva à formação de pigmentos verdes, o que provoca uma diminuição nos valores de a* (vermelho-verde). Segundo o autor, o pico de absorção característico da carne irradiada é de $615 \mathrm{~nm}$. Além disso, os pigmentos verdes formados tendem a desaparecer com o tempo, enquanto os pigmentos vermelhos $(540 \mathrm{~nm})$ permanecem estáveis. A irradiação de carnes (e produtos) também leva à formação de metamioglobina, colaborando com as mudanças na cor das amostras, que mudam de vermelho para acastanhado (GALÁN; GARCÍA; SELGAS, 2011). No caso de produtos cárneos curados (com adição de nitrito), Ham et al. (2017) sugeriram que a redução da cor vermelha se deve à decomposição do nitrosilo hemocromo, bem como à destruição de moléculas de mioglobina pelos radicais livres formados. Em contraste, alguns autores observaram aumento da intensidade da cor vermelha em produtos de carne irradiada, como salsichas fermentadas (KIM et al, 2012) e presunto seco curado (CAVA et al., 2009). Esse aumento foi explicado como resultante da formação de carboximioglobina, que é mais estável que a oximioglobina (CHOULIARA et al., 2006). 
Figura II. 1- CIE Lab para salsicha com redução de sódio irradiadas em doses de 1,5, 3,0 e 4,5 kGy e não irradiadas com redução de sódio (F0) e sem redução de sódio (F2) durante 60 dias de armazenamento refrigerado $\left(4^{\circ} \mathrm{C}\right)$.

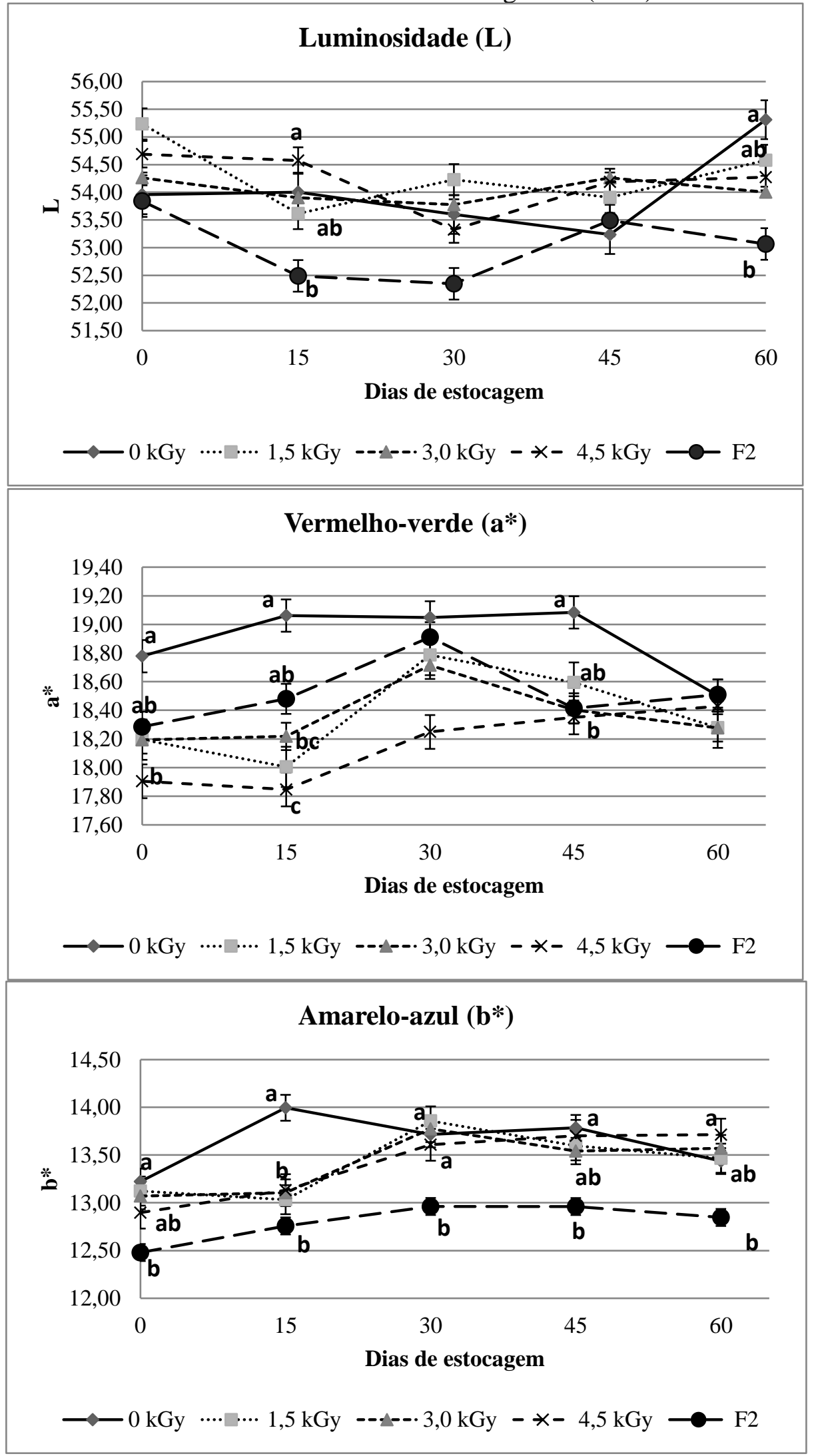

${ }^{a b c}$ letras diferentes indicam diferenças entre formulações. Barras indicam erro padrão. 


\subsection{Análise de perfil de textura}

A análise do perfil de textura revelou diferença $(\mathrm{P}<0,05)$ apenas entre os tratamentos e não ao longo do tempo. A diferença encontrada foi entre F2 e as demais amostras (Figura II.2) para os parâmetros dureza e mastigabilidade. Ou seja, houve diferença apenas em relação à concentração de $\mathrm{NaCl}$ e não em relação à aplicação de radiação. A redução da dureza causada pela redução do $\mathrm{NaCl}$ já foi observada em outros estudos (MARCHETTI et al., 2015; HORITA et al., 2014); e a mastigabilidade está diretamente relacionada à dureza (mastigabilidade $=$ dureza $\mathrm{x}$ coesão $\mathrm{x}$ elasticidade). Essa redução é devida à menor força iônica, menor extração de proteínas e menor resistência do gel em produtos cárneos emulsionados com redução ou substituição de $\mathrm{NaCl}$ (YOTSUYANAGI et al., 2016). Diferentes doses de radiação não afetaram a textura das salsichas $(\mathrm{P}>0,05)$. Park et al. (2010) também demonstraram que a irradiação $(0,5,10,15$ e $20 \mathrm{kGy})$ não afetou a dureza de salsicha. Da mesma forma, Ham et al. (2017) verificaram que a irradiação (raios gama, feixe de elétrons e raios-X m 0, 2,5, 5, 7,5 e 10 kGy) não afetou a dureza das linguiças suína. 
Figura II. 2- Medidas de dureza e mastigabilidade para salsicha com redução de sódio irradiadas com doses de 1,5, 3,0 e 4,5 kGy e salsichas não irradiadas com redução de sódio

(F0) e sem redução de sódio (F2) durante 60 dias de armazenamento refrigerado $\left(4{ }^{\circ} \mathrm{C}\right)$.

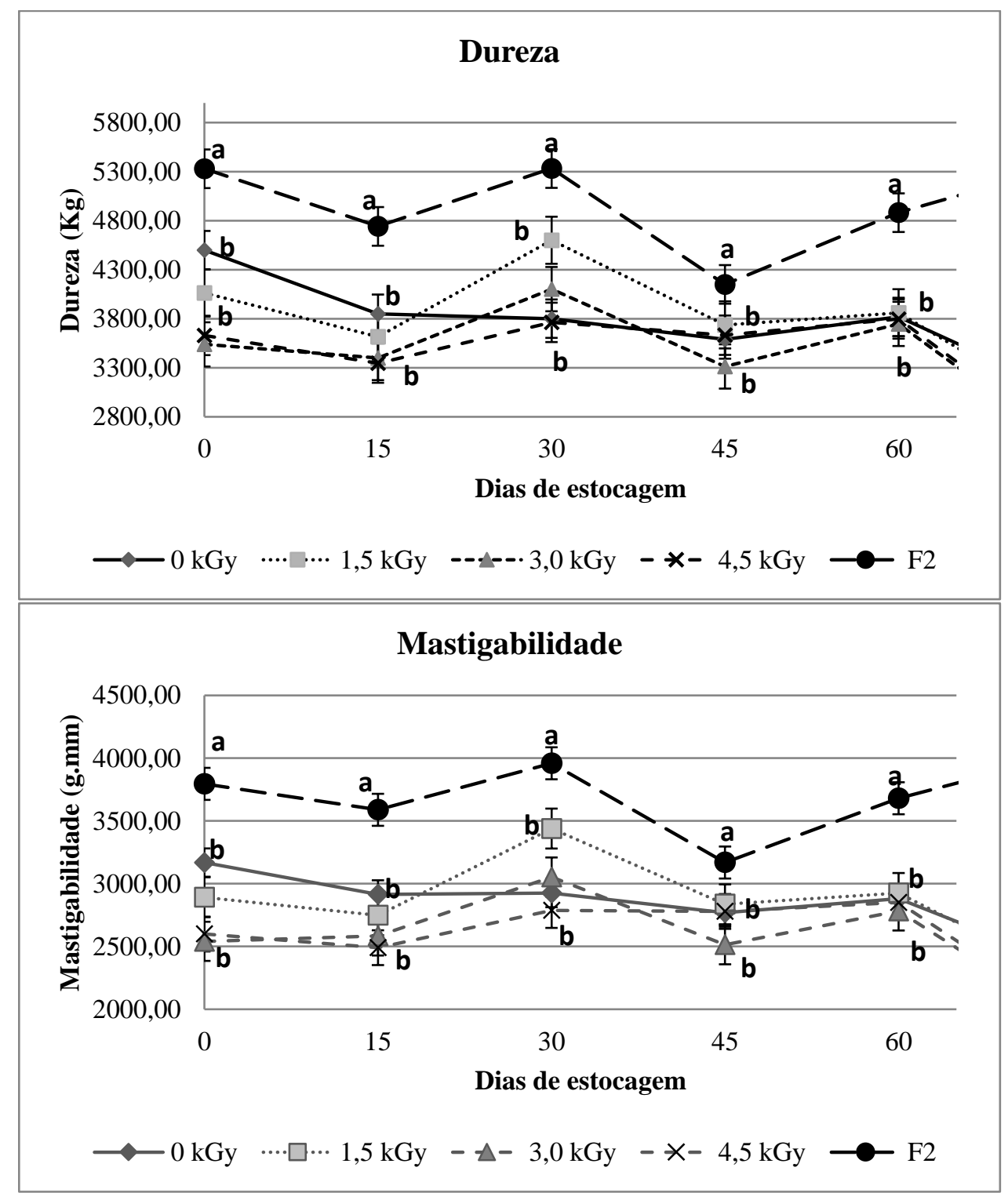

${ }^{a b c} l e t r a s$ diferentes indicam diferenças entre formulações. Barras indicam erro padrão.

\subsection{Análises Microbiológicas}

Nas análises microbiológicas foram estudados os seguintes patógenos: Salmonella $s p$ (presença ou ausência) e contagem de coliformes termotolerantes, Estafilococos coagulase positiva e Clostrídios sulfito redutores. Nenhuma presença quantificável de qualquer um dos patógenos avaliados foi verificada. O crescimento de bactérias deteriorantes (Psicrotróficos anaeróbicos e bactérias ácido lácticas) está descrito na Tabela II.3. A legislação brasileira não 
estabelece limites máximos para contagens de bactérias lácticas e microrganismos psicrotróficos. Entretanto, o crescimento destas bactérias deve ser controlado a fim de evitar alterações no produto, como aumento de acidez e alterações sensoriais, causadas pela geração de metabólitos durante a proliferação destes microrganismos.

Uma redução efetiva do crescimento bacteriano foi observada em amostras irradiadas, especialmente para os tratamentos expostos a 3,0 e 4,5 kGy. A redução da carga microbiana foi mais efetiva com o aumento da dose aplicada (efeito dose dependente). Amostras irradiadas com 3,0 e 4,5 kGy tiveram quase duas reduções de ciclos log de bactérias lácticas em comparação com F2 e mais de 2 ciclos logs em comparação com F0 no tempo inicial de armazenamento. $\mathrm{O}$ crescimento microbiano foi mais lento em salsichas irradiadas durante o tempo de armazenamento, e essas diferenças na carga microbiana se tornaram ainda mais evidentes ao longo do tempo.

O efeito dose dependente da radiação na redução da carga microbiana de produtos cárneos é bem conhecido (FADHEL et al., 2016, FREGONESI et al., 2014, JOUKI et al., 2013, KIM et al., 2010). No entanto, este estudo demonstra que é possível produzir produtos cárneos mais saudáveis (reduzindo o sódio) sem comprometer a segurança alimentar, uma vez que o sal $(\mathrm{NaCl})$ é conhecido por ser um agente bacteriostático, através do uso da radiação gama. Além disso, um grande aumento no prazo de validade pode ser obtido para a salsicha irradiada em qualquer dose.

Os resultados também mostraram que as bactérias ácido-lácticas são mais sensíveis à presença de sal do que bactérias psicrotróficas anaeróbicas, uma vez que as primeiras apresentaram menor taxa de crescimento quando mais sal foi adicionado à formulação, ou seja, menor que F0. Desta forma, as bactérias ácido-lácticas são a principal causa de deterioração em salsichas com sódio reduzido. O crescimento dessas bactérias com consequente geração de ácido lático contribui para a redução do $\mathrm{pH}$ do produto. Da mesma 
forma, Fadhel et al. (2016) verificaram que a adição de marinada (manga, curry, água, frutose, glicose, cebola, alho, sal, óleo de canola e vinagre) a produtos cárneos também reduziu o crescimento de bactérias lácticas. A combinação subsequente de marinada com 1,5 kGy de radiação gama reduziu a contagem destas bactérias para níveis abaixo do limite de detecção.

Tabela II. 3- Crescimento de bactérias lácticas e bactérias psicrotróficas anaeróbias durante 75 dias de armazenamento refrigerado de salsichas com 1,25 ou $2 \%$ de $\mathrm{NaCl}$ submetidas a diferentes doses de radiação

\begin{tabular}{|c|c|c|c|c|c|c|}
\hline & Tempo & I0 & I1.5 & I3.0 & I 4.5 & I2 \\
\hline \multirow{6}{*}{$\begin{array}{c}\text { Bactérias } \\
\text { Lácticas (Log } \\
\text { UFC/g) }\end{array}$} & Inicial & 2,41 & 2,11 & $<1,00$ & $<1,00$ & 1,96 \\
\hline & 15 dias & 3,67 & 1,64 & $<1,00$ & $<1,00$ & 3,61 \\
\hline & 30 dias & 5,81 & 1,00 & $<1,00$ & $<1,00$ & 4,14 \\
\hline & 45 dias & 7.80 & 3.78 & 0,52 & 0,92 & 5,46 \\
\hline & 60 dias & 7,94 & 4,64 & 2,01 & 0,92 & 5,35 \\
\hline & 75 dias & 7,57 & 2,24 & $<1,00$ & $<1,0$ & 7,30 \\
\hline \multirow{6}{*}{$\begin{array}{c}\text { Psicrotróficos } \\
\text { anaeróbicos } \\
\text { (Log UFC/g) }\end{array}$} & Inicial & 2,80 & 1,75 & 1,12 & 0,82 & 2,48 \\
\hline & 15 dias & 4,27 & 2,17 & $<1,00$ & $<1,00$ & 4,31 \\
\hline & 30 dias & 5,00 & 4,85 & $<1,00$ & $<1,00$ & 5,10 \\
\hline & 45 dias & 5,83 & 2,72 & 2,65 & 2,55 & 5,71 \\
\hline & 60 dias & 6,90 & 3,12 & 2,89 & 2,64 & 6,66 \\
\hline & 75 dias & 5,74 & $<1,00$ & $<1,00$ & $<1,00$ & 6,03 \\
\hline
\end{tabular}

UFC $=$ Unidades formadoras de colonia

F0: Salsicha com 1,25\% NaCl sem irradiação / I1.5: Salsicha com 1,25\% NaCl irradiada com uma dose de 1,5 kGy / I3.0: Salsicha com 1,25\% NaCl irradiada com 3,0 kGy / I4.5: Salsicha com 1,25\% NaCl irradiada com uma dose de 4,5 kGy / F2: salsicha com $2 \%$ de $\mathrm{NaCl}$, sem irradiar.

\subsection{Análise sensorial}

O teste sensorial, realizado na primeira semana de armazenamento, mostrou diferença na aceitação das salsichas principalmente em relação à quantidade de sal nas formulações 
(Tabela II.4). Ou seja, as amostras F2 diferiram das outras amostras na maioria dos atributos. Diferenças na aceitação indicaram que os consumidores brasileiros não aceitaram a intensidade de gosto salgado da formulação F2. Esses resultados podem sinalizar as crescentes mudanças nos hábitos alimentares da população, que, ao buscar reduzir a ingestão de sódio em sua dieta, reeducam o paladar e tornam-se mais críticos sobre esse atributo.

Em geral, a irradiação de alimentos leva ao desenvolvimento de sabores e aromas estranhos. Esses aromas se devem à geração de diversos compostos sulfurosos, altamente voláteis (GALÁN; GARCIA; SELGAS, 2011). Esses sabores são gerados pela degradação de aminoácidos e têm sido descritos como doce, velho, sulfuroso ou pungente (AHN, JO, OLSON, 2000). Segundo Brewer (2009), a irradiação também leva à formação de alcanos e alcenos pela decomposição de ácidos graxos insaturados e aminoácidos. Essa decomposição resulta em compostos voláteis como pentanal, hexanal, heptanal, (E) -2-heptanal, octanal, 1octeno, (Z) -octenal, (E) -octenal e (E, Z) -2,4- decadienal que pode produzir odores pungentes, rançosos e de mofo.

Neste estudo, não houve diferença na aceitação das amostras irradiadas em relação à amostra controle (F0). Al-Bachir e Zeinou (2009) explicam que o uso de uma embalagem selada é um método muito eficaz para reduzir a geração de aromas e sabores, pois são gerados pela oxidação dos compostos. No entanto, uma vez que o nível de oxidação lipídica das salsichas irradiadas no tempo inicial foi superior ao das salsichas não irradiadas, é provável que os aromas estranhos resultantes da irradiação fossem mascarados pelo condimento da salsicha. Galán, García e Selgas (2011), entretanto, verificaram que mortadela irradiadas com uma dose de $4 \mathrm{kGy}$ foram menos preferidas pelos consumidores do que as não irradiadas e do que aquelas irradiadas com $2 \mathrm{KGy}$ ou $3 \mathrm{KGy}$. Um painel semi-treinado reconheceu odores doce, de sangue e sulfeto em salsichas fermentadas irradiadas com uma dose de 2 kGy (LIM et al., 2008). 
Tabela II. 4- Resultados do teste sensorial de aceitação de salsichas com 1,25 ou $2 \%$ de $\mathrm{NaCl}$ submetidas a diferentes doses de radiação

\begin{tabular}{llllll}
\hline Formulação & Aparência & Aroma & Textura & Sabor & $\begin{array}{c}\text { Qualidade } \\
\text { Global }\end{array}$ \\
\hline $\mathrm{I} 0$ & $6,04^{\mathrm{AB}}$ & $6,13^{\mathrm{A}}$ & $6,23^{\mathrm{AB}}$ & $6,75^{\mathrm{AB}}$ & $6,43^{\mathrm{AB}}$ \\
$\mathrm{I} 1,5$ & $6,04^{\mathrm{AB}}$ & $6,12^{\mathrm{A}}$ & $5,70^{\mathrm{B}}$ & $6,21^{\mathrm{B}}$ & $6,07^{\mathrm{B}}$ \\
$\mathrm{I} 3,0$ & $6,40^{\mathrm{A}}$ & $6,54^{\mathrm{A}}$ & $6,58^{\mathrm{A}}$ & $6,94^{\mathrm{A}}$ & $6,82^{\mathrm{A}}$ \\
$\mathrm{I} 4,5$ & $6,28^{\mathrm{A}}$ & $6,50^{\mathrm{A}}$ & $6,50^{\mathrm{A}}$ & $6,81^{\mathrm{AB}}$ & $6,56^{\mathrm{AB}}$ \\
$\mathrm{I} 2$ & $5,58^{\mathrm{B}}$ & $6,06^{\mathrm{A}}$ & $4,38^{\mathrm{C}}$ & $5,55^{\mathrm{C}}$ & $5,34^{\mathrm{C}}$ \\
\hline
\end{tabular}

Desgostei extremamente, 2 = Desgostei muito, 3 = Desgostei moderadamente, 4 = Desgostei um pouco, $5=$ Não gostei nem desgostei, 6 = Gostei um pouco, 7 = Gostei moderadamente, $8=$ Gostei muito, 9 = Gostei extremamente) .

\section{CONCLUSÃO}

A irradiação mostrou-se um método eficaz para reduzir a carga microbiana e garantir a segurança de salsichas com reduzido teor de sódio. Essa tecnologia teve ótimos resultados em testes microbianos mesmo na menor dose estudada (I1.5). A irradiação na dose de 1,5 kGy é, portanto, a mais indicada, pois proporciona os benefícios da segurança microbiológica e menores efeitos nos atributos de qualidade do produto. 


\section{REFERÊNCIAS}

AHN, Dong U.; JO, Cheorun; OLSON, D. G. Analysis of volatile components and the sensory characteristics of irradiated raw pork. Meat Science, v. 54, n. 3, p. 209-215, 2000.

AL-BACHIR, M.; ZEINOU, R. Effect of gamma irradiation on microbial load and quality characteristics of minced camel meat. Meat science, v. 82, n. 1, p. 119-124, 2009.

AMARAL, D. S. et al. Effect of storage time and packaging on the quality of lamb pâté prepared with 'variety meat'. Food packaging and shelf life, v. 3, p. 39-46, 2015.

BREWER, Susan. Irradiation effects on meat color-a review. Meat Science, v. 68, n. 1, p. 117, 2004.

CAVA, Ramón et al. Decolouration and lipid oxidation changes of vacuum-packed Iberian dry-cured loin treated with E-beam irradiation (5 kGy and $10 \mathrm{kGy}$ ) during refrigerated storage. Innovative food science \& emerging technologies, v. 10, n. 4, p. 495-499, 2009.

CHENG, Anwei et al. Effect of irradiation and storage time on lipid oxidation of chilled pork. Radiation Physics and Chemistry, v. 80, n. 3, p. 475-480, 2011.

CHOULIARA, I. et al. Effect of irradiation of frozen meat/fat trimmings on microbiological and physicochemical quality attributes of dry fermented sausages. Meat science, v. 74, n. 2, p. 303-311, 2006.

DAS, Arun K. et al. Effect of full-fat soy paste and textured soy granules on quality and shelflife of goat meat nuggets in frozen storage. Meat science, v. 80, n. 3, p. 607-614, 2008.

DUSSAULT, Dominic; BENOIT, C.; LACROIX, Monique. Combined effect of $\gamma$-irradiation and bacterial-fermented dextrose on microbiological quality of refrigerated pork sausages. Radiation Physics and Chemistry, v. 81, n. 8, p. 1098-1102, 2012.

EHLERMANN, Dieter AE. Particular applications of food irradiation: Meat, fish and others. Radiation Physics and Chemistry, v. 129, p. 53-57, 2016.

FADHEL, Yosra Ben et al. Combined effects of marinating and $\gamma$-irradiation in ensuring safety, protection of nutritional value and increase in shelf-life of ready-to-cook meat for immunocompromised patients. Meat science, v. 118, p. 43-51, 2016.

FENG, Xi et al. Effect of irradiation on the parameters that influence quality characteristics of raw turkey breast meat. Radiation Physics and Chemistry, v. 130, p. 40-46, 2017. 
FREGONESI, R. P. et al. Irradiated vacuum-packed lamb meat stored under refrigeration: Microbiology, physicochemical stability and sensory acceptance. Meat science, v. 97, n. 2, p. 151-155, 2014.

GALÁN, I.; GARCÍA, MaL; SELGAS, MaD. Irradiation is useful for manufacturing readyto-eat cooked meat products enriched with folic acid. Meat science, v. 87, n. 4, p. 330-335, 2011.

HAM, Youn-Kyung et al. Effects of irradiation source and dose level on quality characteristics of processed meat products. Radiation Physics and Chemistry, v. 130, p. 259-264, 2017.

HARDER M.N.C., ARTHUR V. AND ARTHUR P.B. Irradiation of Foods: Processing Technology and Effects on Nutrients: Effect of Ionizing Radiation on Food Components. In: Caballero, B., Finglas, P., and Toldrá, F. (eds.) The Encyclopedia of Food and Health vol. 3, pp. 476-481. Oxford: Academic Press. 2016.

HORITA, C. N. et al. Textural, microstructural and sensory properties of reduced sodium frankfurter sausages containing mechanically deboned poultry meat and blends of chloride salts. Food research international, v. 66, p. 29-35, 2014.

HWANG, Ko-Eun et al. Effects of antioxidant combinations on shelf stability of irradiated chicken sausage during storage. Radiation Physics and Chemistry, v. 106, p. 315-319, 2015.

INGUGLIA, Elena S. et al. Salt reduction strategies in processed meat products-A review. Trends in Food Science \& Technology, v. 59, p. 70-78, 2017.

JOUKI, M. Evaluation of gamma irradiation and frozen storage on microbial load and physico-chemical quality of turkey breast meat. Radiation Physics and Chemistry, v. 85, p. 243-245, 2013.

KIM, Hyun-Jin et al. Effects of electron beam irradiation on the microbial growth and quality of beef jerky during storage. Radiation Physics and Chemistry, v. 79, n. 11, p. 1165-1168, 2010 .

KIM, I. S. et al. Effects of low-level gamma irradiation on the characteristics of fermented pork sausage during storage. Radiation Physics and Chemistry, v. 81, n. 4, p. 466-472, 2012. 
LARANJO, Marta et al. Characterisation of "Catalão" and "Salsichão" Portuguese traditional sausages with salt reduction. Meat science, v. 116, p. 34-42, 2016.

LBERTY, J. T. et al. An Overview of the principles and effects of irradiation on food processing \& preservation. International Journal of Multidisciplinary and Current Research, v. 1, p. 236-243, 2013.

LIM, D. G. et al. Application of electron-beam irradiation combined with antioxidants for fermented sausage and its quality characteristic. Radiation Physics and Chemistry, v. 77, n. 6, p. 818-824, 2008.

MARCHETTI, Lucas et al. Sodium-reduced lean sausages with fish oil optimized by a mixture design approach. Meat science, v. 104, p. 67-77, 2015.

MEILGAARD, Morten C.; CARR, B. Thomas; CIVILLE, Gail Vance. Sensory evaluation techniques. CRC press, 1991.

MOY, J. H. Food irradiation — an emerging technology. Novel food processing technologies. 2005.

PARK, J. G. et al. Effects of gamma irradiation and electron beam irradiation on quality, sensory, and bacterial populations in beef sausage patties. Meat science, v. 85, n. 2, p. 368$372,2010$.

STANLEY, Regan E.; BOWER, Chad G.; SULLIVAN, Gary A. Influence of sodium chloride reduction and replacement with potassium chloride based salts on the sensory and physicochemical characteristics of pork sausage patties. Meat science, v. 133, p. 36-42, 2017.

TRINDADE, R. A. et al. Consumer's evaluation of the effects of gamma irradiation and natural antioxidants on general acceptance of frozen beef burger. Radiation Physics and Chemistry, v. 78, n. 4, p. 293-300, 2009.

VINCKE, W. Direct of the Thiobarbituric Acid Value in Trichlorcetic Acid Extracts of Fish as a Measure of Oxidative Rancidity. Fette Seifen Anstrichmittel, Leifekden, v.72, n.12 p184-1087, 1970.

WHO. Wholesomeness of Irradiated Foods. World Health Organization.

Technical Report Series 659. Geneva. 1981. 
YU, Ligang et al. Effect of irradiation on $\mathrm{N} \varepsilon$-carboxymethyl-lysine and $\mathrm{N} \varepsilon$-carboxyethyllysine formation in cooked meat products during storage. Radiation Physics and Chemistry, v. 120, p. 73-80, 2016. 


\section{CAPÍTULO III -PERCEPÇÃO DO CONSUMIDOR SOBRE O USO DA RADIAÇÃO PARA PRODUZIR PRODUTOS CÁRNEOS MAIS SAUDÁVEIS}

Artigo: UNDERSTANDING CONSUMERS FEARS AND PERCEPTIONS ABOUT THE USE OF RADIATION TO PRODUCE HEALTHIER MEAT PRODUCTS

Isabela Rodrigues*, Manoela Pires, Julliane C. Barros, Yana J. P. Rocha, Marco Antonio Trindade 


\section{RESUMO}

A percepção do consumidor sobre um determinado alimento ou tecnologia é extremamente importante para o sucesso deste produto no mercado. No caso de novos produtos ou alimentos produzidos com tecnologias não convencionais, a compreensão da percepção do consumidor é ainda mais crítica. Neste estudo, duas ferramentas foram utilizadas para entender a percepção do consumidor sobre a irradiação aplicada na produção de salsichas com redução de sódio: 1) Food Neophobia Technology Scale (FTNS) foi aplicada a 259 consumidores para avaliar como o conhecimento / informação sobre uma tecnologia afeta a neofobia e 2) Focus Group (em quatro sessões com oito consumidores cada) foi realizado para entender as crenças do consumidor relacionadas à aceitação ou rejeição deste produto. Adicionalmente, o teste Check-all-that-apply foi aplicado para caracterizar salsichas irradiadas com redução de sódio. Resultados gerais indicaram uma separação na aceitação da tecnologia em relação à idade e nível de conhecimento dos participantes. Os resultados da FTNS indicaram que participantes com mais de 30 anos eram mais neofóbicos do que os mais jovens; a apresentação de informações sobre a irradiação não alterou a pontuação geral do FTNS, ou seja, não diminuiu a neofobia em relação a esta tecnologia. No Focus Group, grupos de participantes mais velhos, que tinham filhos e que não eram estudantes de graduação ou pós-graduação, mostraram-se mais resistentes a aceitar alimentos irradiados do que os outros grupos. Salsichas irradiadas tiveram descrições semelhantes a salsichas não irradiadas no CATA. A irradiação de alimentos ainda desperta grande receio na população, para que esta tecnologia seja aceita, os consumidores precisam entender profundamente seu uso e efeitos.

Palavras-chave: FTNS, Focus Group, CATA, Irradiação, Salsicha. 


\section{INTRODUÇÃO}

A neofobia alimentar é descrita como um traço de personalidade ou peculiaridade que separa as pessoas em termos de sua tendência a aceitar ou rejeitar novos alimentos (SCHNETTLER et al., 2013). Segundo Vidigal et al. (2015) o mercado globalizado pode ser dividido em dois grupos principais: de um lado, um grupo de pessoas que anseiam por modernidades (alimentos funcionais e de conveniência, alimentos de baixa caloria e baixo teor de sódio) e, por outro, pessoas que preferem alimentos mais naturais (como os alimentos orgânicos).

De acordo com Barrena e Sanchés (2012) a chegada de uma variedade de novos alimentos no mercado criou um clima ambivalente ou de insegurança, no qual algumas inovações encontram oposição ou suspeita, enquanto outras são rapidamente incorporadas à rotina alimentar. Além disso, segundo Deliza, Rosenthal e Silva (2003) e Strijbos et al. (2016) verifica-se um aumento da demanda por alimentos saudáveis e nutritivos, o que é decorrente do surgimento de um perfil de consumidores mais informados e exigentes quanto aos alimentos que consomem.

Neste contexto, os consumidores atuais estão expostos a uma ampla variedade de novos produtos e tecnologias (ROLLIN; KENNEDY; WILLS, 2011; VAN WEZEMAEL et al., 2012; VIDIGAL et al., 2015), mas nem todas essas tecnologias são prontamente aceitas ou entendidas por eles. Características individuais que afetam a atitude de um consumidor em relação a uma determinada tecnologia podem contribuir para a aceitação ou rejeição do respectivo alimento (DE BARCELLOS et al., 2010). Entender a percepção do consumidor de um determinado alimento e a tecnologia usada em sua fabricação é, portanto, essencial para entender sua decisão de compra. Além disso, as informações fornecidas ou apresentadas na 
embalagem do produto são particularmente relevantes em casos de produtos inovadores, quando não há experiência de consumo anterior (DE ANDRADE et al., 2018).

A avaliação de riscos ou perigos relacionados a alimentos muitas vezes difere entre indivíduos com habilidades técnicas e simples consumidores (DE BARCELLOS et al., 2010; FREWER; DE JONGE; VAN KLEEF, 2009; PERREA; GRUNERT; KRYSTALLIS, 2015). Por exemplo, segundo Nielsen et al. (2009), muitos consumidores preferem métodos de produção tradicionais, como alimentos orgânicos, em vez de modificação genética, enquanto os cientistas estão recebendo entusiasticamente tais avanços tecnológicos. Uma possível razão para isso é que as tecnologias de produção são questões altamente técnicas, de modo que os consumidores em geral provavelmente não têm um conhecimento claro do que essas tecnologias implicam (NIELSEN et al., 2009).

Uma consequência direta dessa situação é que alguns novos produtos e tecnologias, apesar de seus potenciais benefícios, podem ter dificuldade em serem comercializados (DE BARCELLOS et al., 2010; ROLLIN; KENNEDY; WILLS, 2011). Por outro lado, há uma demanda crescente por alimentos funcionais, de conveniência e mais saudáveis (VIDIGAL et al., 2015), os quais normalmente precisam de algum novo processo / tecnologia para serem produzidos (TROY et al., 2016).

Como a percepção do consumidor é uma questão de extrema importância para o sucesso de um produto no mercado, diversas metodologias podem ser utilizadas para obter esse entendimento. A Food Technology Neophobia Scale (FTNS) é uma escala criada por Cox e Evans (2008), que visa identificar segmentos de consumidores que aceitam ou rejeitam novas tecnologias aplicadas à produção de alimentos. A aceitação é avaliada atribuindo pontuações que variam de um a sete em uma lista com 13 declarações (somatório variando de 13 a 91). A FTNS surgiu da necessidade de avaliar especificamente a aceitação pelo consumidor de uma tecnologia aplicada a um alimento, ao invés do próprio alimento. 
Check-all-that-apply (CATA) é uma metodologia que permite a caracterização sensorial de produtos por consumidores. Uma de suas principais vantagens é que o consumidor pode selecionar vários atributos para o mesmo produto, em vez de focar apenas em um aspecto (DOS SANTOS et al., 2015). As palavras ou frases incluídas no questionário CATA poderiam ser descritores usados por um painel de avaliadores treinados ou selecionadas de Focus Group anteriores ou estudos quantitativos de consumidores (DOOLEY; LEE; MEULlENET, 2010; VARELA; ARES, 2012). No entanto, um dos principais paradigmas da análise sensorial é que muitas vezes os atributos de um determinado alimento são levantados inicialmente por um painel treinado. Somente após a seleção dos descritores os consumidores são questionados sobre como eles percebem esses atributos; ou seja, os consumidores não têm a oportunidade de expressar como percebem essas características desde o início. Um problema relacionado a isso é que alguns atributos levantados pelo painel treinado podem não ser relevantes para os consumidores, ou esses atributos podem ser descritos pelo painel de uma maneira diferente da que os consumidores descreveriam (ARES; JAEGER, 2013; DOOLEY; LEE; MEULLENET, 2010).

Uma maneira simples de obter a opinião de um consumidor sobre um determinado produto é por meio do diálogo. O grupo focal (Focus Group) é uma metodologia muito útil nesses casos (DELIZA; ROSENTHAL; SILVA, 2003). Basicamente, o grupo focal é uma técnica de coleta de dados que combina os princípios da pesquisa qualitativa e o conhecimento da dinâmica de pequenos grupos (CAREY, 2015). As atitudes dos consumidores em relação a uma nova tecnologia aplicada a produtos cárneos também levam em conta considerações morais e éticas, e não estão associadas apenas a benefícios pessoais e efeitos à saúde (TROY et al., 2016). Nesse caso, Focus Groups podem ser usados para identificar e explorar as principais preocupações de um tópico que é novo ou não é bem compreendido. A formação de atitudes é idealmente estudada em um grupo focal, uma vez 
que os participantes são mais motivados a formar novas atitudes pela interação com outros participantes (Nielsen et al., 2009). Além disso, o vocabulário natural dos participantes pode ser usado no desenvolvimento de itens para um questionário, ou quando já existe um questionário que será aplicado em uma população diferente da que foi desenvolvido, o Focus Group pode ser usado para entender o significado dos itens explorados (CAREY, 2015).

Um caso particular de como a percepção do consumidor afeta o sucesso de um produto no mercado é a irradiação de alimentos. Embora considerada segura e eficaz pela comunidade científica, essa técnica de preservação não foi inicialmente aceita pelos consumidores (VIDIGAL et al., 2015). No entanto, de acordo com Ehlermann (2016), após mais de 100 anos de questionamentos sobre a irradiação de alimentos, os consumidores atuais estão mais abertos a aceitar alimentos irradiados, onde estão disponíveis, juntamente com uma explicação sobre esta tecnologia.

Paralelamente, a redução de sódio em produtos cárneos tem sido amplamente estudada e faz parte de uma tendência mundial de redução do consumo de sódio (AASLYNG; VESTERGAARD; KOCH, 2014; DOS SANTOS et al., 2014, LILIC et al., 2015, MCGOUGH et al., 2012). A forma mais simples de se reduzir o teor de sódio em produtos cárneos é a redução direta do teor cloreto de sódio $(\mathrm{NaCl})$ adicionado. No entanto, do ponto de vista microbiológico, a redução de cloreto de sódio nos alimentos é problemática devido ao seu efeito bacteriostático (LOBO et al., 2016). Assim, a irradiação seria uma alternativa muito eficaz para garantir a segurança microbiológica desses alimentos (KANATT; CHANDER; SHARMA, 2005; PARK et al., 2010).

Este estudo foi realizado com o objetivo de compreender a percepção, ou seja, as opiniões, medos e créditos que as pessoas atribuem às tecnologias não convencionais (especificamente a irradiação) aplicadas no processamento de alimentos, por meio das técnicas de grupo focal (focus group) e escala FTNS. O grupo focal também foi utilizado para 
selecionar os descritores para o teste Check-all-that-apply aplicado para caracterizar salsichas com redução de sódio e irradiadas com diferentes doses de raios gama (zero; 1,5; 3,0 e 4,5 $\mathrm{kGy})$.

\section{MATERIAIS E MÉTODOS}

\subsection{Food Neophobia Technology Scale - FTNS}

A fim de avaliar a percepção do consumidor sobre alimentos irradiados, três métodos de estudo foram aplicados. Inicialmente, a ferramenta Food Technology Neophobia Scale (COX; EVANS, 2008) foi aplicada a 259 consumidores de salsicha, dentre alunos e funcionários da Universidade de São Paulo e militares da Academia da Força Aérea Brasileira. A escala foi traduzida e validada do inglês para o português por Vidigal et al. (2015). Ambas as versões estão disponíveis no Anexo 1. Nesta etapa, os participantes responderam ao questionário sem receber nenhuma informação sobre o processo, objetivos e consequências da irradiação de alimentos. $\mathrm{O}$ objetivo desta fase foi avaliar a percepção do consumidor de uma tecnologia que ele ainda não conhece. Um mês após a aplicação deste primeiro teste, o mesmo questionário foi aplicado novamente. No entanto, juntamente com o questionário, os participantes receberam uma explicação (Anexo 2) sobre o processo de irradiação de alimentos. A explicação baseou-se nas definições dadas por Rollin, Kennedy e Wills (2011) e consistiu basicamente de três blocos-chave: definir o que é irradiação, qual a sua função e apresentar alguns casos em que a tecnologia é importante. As respostas obtidas nas duas fases foram comparadas para avaliar se e em quais aspectos a informação impacta a percepção do consumidor (SIEGRIST, 2008; VAN WEZEMAEL et al., 2012). 


\subsection{Focus Group}

\subsubsection{Seleção de participantes e grupos}

Um estudo de grupo focal com quatro diferentes grupos de consumidores de salsicha foi conduzido. Cada grupo foi composto por oito participantes, totalizando 32 consumidores. A seleção dos participantes foi baseada nos seguintes critérios:

1 - Consumo regular de salsicha pelo menos uma vez por semana para todos os grupos;

2 - Idade entre 18 e 35 anos para os grupos 1 e 2 ;

Os participantes dos Grupos 1, 2 e 3 foram recrutados entre estudantes e funcionários da Faculdade de Zootecnia e Engenharia de Alimentos - FZEA / USP. Os participantes do grupo 4 foram selecionados entre militares da Academia da Força Aérea (Brasil). Os participantes selecionados, apesar de se adequarem aos critérios de seleção, não representam a população brasileira como um todo. Os critérios de seleção e o roteiro de discussão foram escolhidos com a finalidade de entender se: $\mathrm{O}$ conceito de alimentação saudável difere entre jovens e adultos; Se os jovens estão mais abertos para receber novas tecnologias aplicadas aos produtos cárneos do que os adultos (Eurobarometer, 2005; Rollin, Kennedy, \& Wills, 2011). Se o nível de conhecimento / informação sobre tecnologia influencia sua aceitação; Se as informações no rótulo influenciam a decisão de compra.

O roteiro de discussão foi o mesmo para todos os grupos. Cada sessão durou em torno de 1 h30min e abordou os seguintes pontos:

1- Apresentação dos participantes e seus hábitos alimentares;

2- Discussão sobre o que é ter uma vida saudável e uma alimentação saudável: quais hábitos são considerados saudáveis e quais alimentos são considerados saudáveis; 
3- O que são produtos cárneos? Quais são suas características? Esses produtos são considerados saudáveis?

4- O que poderia torná-los mais saudáveis ou não saudáveis?

5- Irradiação: O que é irradiação de alimentos? O que você acha dessa tecnologia? Qual seria o seu propósito?

6- Quais aspectos impediriam ou encorajariam a consumir alimentos irradiados?

7- Qual símbolo identifica um alimento irradiado? A radura é um símbolo que representa bem um alimento irradiado? Por quê?

8- Você costuma ler o rótulo dos alimentos que consome?

A Figura III.1 ilustra o símbolo radura foi apresentado aos participantes.

Figura III. 1- Símbolo radura, que identifica alimentos irradiados, apresentado aos participantes do Focus Group.

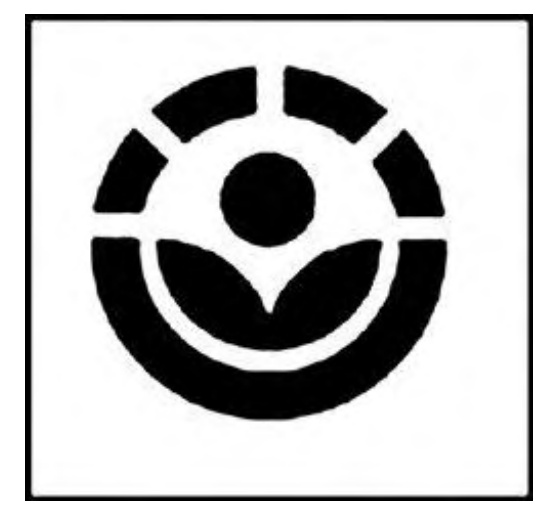

Fonte: Mostafavi; Mirmajlessi; Fathollahi (2012).

\subsection{Check-all-that-apply (CATA)}

Após as discussões em Focus Group todos os participantes foram servidos com três amostras de salsicha: A- Controle (sem redução de sódio e sem irradiação); B - Com redução de sódio sem irradiação e C - Com redução de sódio e irradiada( com a maior dose, 4,5kGy). Cada participante escreveu cinco palavras (atributos) que melhor definiriam cada amostra em 
sua opinião. Em seguida, uma discussão dos atributos definidos foi realizada. Os atributos mais citados em todos os grupos foram selecionados para compor a lista de descritores para o teste CATA. Essa metodologia para coleta de termos foi selecionada com o intuito de garantir, tanto quanto possível, que os atributos escolhidos para compor a listagem do CATA sejam comuns e próximos aos consumidores desse tipo de produto.

O teste CATA foi realizado no Laboratório de Análise Sensorial da Faculdade de Zootecnia e Engenharia de Alimentos da Universidade de São Paulo. Cada consumidor avaliou cinco diferentes tratamentos de salsicha, a saber: 0 kGy (com redução de sódio e sem irradiação), 1,5 kGy (com redução de sódio e irradiado na dose de 1,5kGy), 3,0kGy (com redução de sódio e irradiado na dose de 3,0 kGy) , 4,5 kGy (com redução de sódio e irradiado na dose de 4,50 kGy) e F2 (sem redução de sódio e sem irradiação). Cada participante recebeu as amostras em forma monádica em blocos casualizados. As formulações utilizadas para salsichas com e sem redução de sódio estão descritas na Tabela III.1. Todas as salsichas irradiadas apresentaram a mesma formulação (com redução de sódio) e diferiram apenas na dose de radiação empregada.

Tabela III. 1- Formulações de salsichas irradiadas e não-irradiadas (F2).

\begin{tabular}{lcc}
\hline Ingredientes & $\begin{array}{c}\text { Com redução de } \\
\text { sódio (\%) }\end{array}$ & Controle (F2) (\%) \\
\hline Carne bovina (peixinho - Supraspinatus) & 60 & 60 \\
Toucinho & 10 & 10 \\
Fécula de mandioca (Yoki, Brazil) & 2 & 2 \\
Sal ( $\mathrm{NaCl}$ (Cisne, Brazil) & 1.25 & 2 \\
Nitrito de sódio (Cori, Brazil) & 0.015 & 0.015 \\
Eritorbato de sódio (Cori, Brazil) & 0.05 & 0.05 \\
Tripolifosfato de sódio (Cori, Brazil) & 0.25 & 0.25 \\
Condimento (New max, Brazil) & 0.5 & 0.5 \\
Corante carmim de cochonilha & 0.05 & 0.05 \\
\hline Water/Ice & 25.89 & 25.14 \\
\hline Total $(\boldsymbol{\%})$ & $\mathbf{1 0 0}$ & $\mathbf{1 0 0}$ \\
\hline
\end{tabular}

Com redução de sódio: Formulação utilizada para as amostras F0, I1.5, I3.0 e I4.5 
O processamento das salsichas para o teste foi realizado na Faculdade de Zootecnia e Engenharia de Alimentos da Universidade de São Paulo. O processo de irradiação foi realizado pelo irradiador Cobalto-60 localizado no Instituto de Pesquisas Energéticas Nucleares (IPEN), em São Paulo, Brasil, a uma taxa de $5 \mathrm{kGy} \cdot \mathrm{h}^{-1}$ no modo estático.

\subsection{Análise dos resultados}

Os resultados obtidos por meio da FTNS foram analisados segundo Vidigal et al. (2015) e Cox e Evans (2008). A classificação dos indivíduos foi calculada somando os valores de cada item, variando de 13 a 91, quanto maior o valor, mais neofóbico é o indivíduo. A média total foi calculada dividindo-se a soma de todos os itens pelo número de respondentes. Análise de variância (ANOVA) e teste de Tukey, a 5\% de significância, foram realizados para avaliar diferenças entre as respostas dos grupos com e sem informações sobre irradiação. Diferenças na pontuação de acordo com a idade dos participantes também foram avaliadas. Para analisar os resultados da CATA, foi realizado o teste do qui-quadrado para determinar se havia ligação entre as linhas (tratamentos) e colunas (atributos). A distribuição de amostras em um plano foi visualizada através do gráfico gerado pela Análise de Coordenadas Principais do XLStat (PCoA).

Por se tratar de uma análise qualitativa, os resultados obtidos no Focus Group foram analisados para extrair as principais considerações de cada grupo. Todas as discussões foram gravadas e posteriormente transcritas para melhor aproveitamento dos diálogos. Os principais pontos abordados foram separados em tópicos para comparação entre os grupos. 


\section{RESULTADOS E DISCUSSÃO}

\subsection{Food Neophobia Technology Scale}

Entre os 259 participantes que responderam ao questionário, 53,66\% não receberam informações sobre a tecnologia de irradiação e 46,33\% receberam. Entre esses, $13 \%$ tinham filhos. Os valores médios de neofobia em relação à tecnologia de alimentos foram $42,62( \pm$ $7,46)$ para os consumidores que não receberam informação e $42,20( \pm 7,58)$ para os consumidores que receberam informações. As médias para cada item da escala para consumidores que receberam informações sobre irradiação e os consumidores que não receberam informações estão ilustradas na Tabela III.2. Quando o questionário foi aplicado a um grupo formado por pais (idades entre 30 e 50 anos), a média de neofobia foi de 48,0 ( \pm $9,33)$, sendo 46,0 $( \pm 8,66)$ para mulheres e 48,0 para homens $( \pm 9,34)$. A análise dos resultados indicou diferença significativa entre os grupos de participantes segundo idade e sexo. Participantes menores de 25 anos e participantes entre 26 e 35 anos tiveram média de 42,31 e 41,55, respectivamente, diferente do grupo formado por pessoas acima de 35 anos, que obtiveram média de 48,30, indicando maior neofobia. Mulheres $(40,99)$ foram menos neofóbicas que os homens $(44,98)$.

Ambos os valores da FNTS aplicada aos consumidores com $(42,62 \pm 7,46)$ e sem $(42,20 \pm 7,58)$ informações são próximos ao encontrado por Vidigal et al. (2015), que avaliaram a neofobia dos consumidores brasileiros (em Belo Horizonte) e encontraram uma pontuação de 47 ( \pm 12 ). Desse total, os autores descobriram que a média de neofobia era de 47,5 para mulheres e 46,7 para homens. O maior valor da soma dos itens do FTNS corresponde à menor receptividade dos consumidores às novas tecnologias. Assim, comparando a pontuação média da FTNS com as de outros estudos, podemos concluir que os consumidores brasileiros apresentam menor neofobia do que consumidores italianos $(60,9 \pm$ 11,3, Verneau et al., 2014), canadenses (58,45, Martin et al., 2012) e australianos (54,3, Evans 
et al., 2010). Ao comparar consumidores informados e não informados sobre o processo de irradiação, diferenças foram encontradas apenas nos itens 1, 5, 10 e 12.

O primeiro item (Eu não estou totalmente familiarizado com tecnologias não convencionais empregadas na produção elou processamento de alimentos.) teve uma pontuação mais alta para consumidores que não receberam informações. Isso faz sentido, já que apresentar informações aos consumidores elimina ou reduz suas incertezas em relação à tecnologia. O quinto item (Tecnologias não convencionais empregadas na produção elou processamento de alimentos reduzem a qualidade natural dos alimentos.) recebeu uma pontuação maior dos consumidores informados, ou seja, após conhecerem o processo de irradiação, os consumidores concluíram que esse processo poderia diminuir a qualidade dos alimentos. O décimo item (Pode ser arriscado mudar rapidamente para tecnologias não convencionais empregadas na produção elou processamento de alimentos.) recebeu uma pontuação mais alta dos consumidores informados, indicando que depois de conhecer a tecnologia, os consumidores consideraram arriscado adotá-la imediatamente. Finalmente, o décimo segundo item (Não faz sentido experimentar alimentos produzidos a partir de alta tecnologia, porque os que eu consumo já são bons o suficiente.) também recebeu uma pontuação mais alta dos consumidores que receberam informações, o que indica que os consumidores não percebem os benefícios do uso da irradiação para o processamento de produtos cárneos.

Estes resultados indicam que, embora haja um consenso de que a informação aumenta o nível de aceitação de uma determinada tecnologia no processamento de alimentos, no caso da irradiação, isso não ocorre. Muitos consumidores ainda veem essa tecnologia como arriscada, e mudar essa percepção provavelmente exigirá mais dedicação dos cientistas do que apenas dar informações sobre a tecnologia. 
Tabela III. 2- Médias das pontuações atribuídas a cada item da FTNS por consumidores informados (I) e não informados (NI) sobre a tecnologia de irradiação.

\begin{tabular}{|c|c|c|}
\hline Declarações & Média I & Média NI \\
\hline $\begin{array}{l}\text { 1. Eu não estou totalmente familiarizado com tecnologias não convencionais empregadas na produção e/ou processamento de } \\
\text { alimentos. }\end{array}$ & $3.35^{\mathrm{b}}$ & $4.02^{\mathrm{a}}$ \\
\hline 2. Novos alimentos não são mais saudáveis do que os alimentos tradicionais. & $2.57^{\mathrm{a}}$ & $2.53^{\mathrm{a}}$ \\
\hline $\begin{array}{l}\text { 3. As afirmações sobre os benefícios de tecnologias não convencionais empregadas na produção e/ou processamento de alimentos } \\
\text { são frequentemente muito exageradas. }\end{array}$ & $3.24^{\mathrm{a}}$ & $3.46^{\mathrm{a}}$ \\
\hline $\begin{array}{l}\text { 4. Já existem inúmeros alimentos saborosos no mercado, então nós não precisamos de tecnologias não convencionais para produzir } \\
\text { mais alimentos. }\end{array}$ & $1.50^{\mathrm{a}}$ & $1.39^{\mathrm{a}}$ \\
\hline $\begin{array}{l}\text { 5. Tecnologias não convencionais empregadas na produção e/ou processamento de alimentos reduzem a qualidade natural dos } \\
\text { alimentos. }\end{array}$ & $2.57^{\mathrm{a}}$ & $2.12^{\mathrm{b}}$ \\
\hline $\begin{array}{l}\text { 6. Tecnologias não convencionais empregadas na produção e/ou processamento de alimentos provavelmente não trarão, em longo } \\
\text { prazo, efeitos negativos à saúde. }\end{array}$ & $4.18^{\mathrm{a}}$ & $4.07^{\mathrm{a}}$ \\
\hline $\begin{array}{l}\text { 7. Tecnologias não convencionais empregadas na produção e/ou processamento de alimentos proporcionam às pessoas um maior } \\
\text { controle sobre as suas escolhas alimentares. }\end{array}$ & $4.83^{\mathrm{a}}$ & $4.79^{\mathrm{a}}$ \\
\hline 8. Novos produtos que utilizam tecnologias não convencionais podem ajudar as pessoas a terem uma dieta equilibrada. & $5.34^{\mathrm{a}}$ & $5.18^{\mathrm{a}}$ \\
\hline $\begin{array}{l}\text { 9. Tecnologias não convencionais empregadas na produção e/ou processamento de alimentos podem causar, em longo prazo, } \\
\text { efeitos negativos ao meio ambiente. }\end{array}$ & $3.60^{\mathrm{a}}$ & $3.59^{\mathrm{a}}$ \\
\hline $\begin{array}{l}\text { 10. Pode ser arriscado mudar rapidamente para tecnologias não convencionais empregadas na produção e/ou processamento de } \\
\text { alimentos. }\end{array}$ & $3.85^{\mathrm{a}}$ & $3.37^{\mathrm{b}}$ \\
\hline 11. A sociedade não deve depender demais de tecnologias para resolver os seus problemas alimentares. & $2.68^{\mathrm{a}}$ & $3.04^{\mathrm{a}}$ \\
\hline $\begin{array}{l}\text { 12. Não faz sentido experimentar alimentos produzidos a partir de alta tecnologia, porque os que eu consumo já são bons o } \\
\text { suficiente. }\end{array}$ & $1.74^{\mathrm{a}}$ & $1.48^{\mathrm{b}}$ \\
\hline $\begin{array}{l}\text { 13. A mídia geralmente fornece uma visão equilibrada e imparcial das tecnologias não convencionais empregadas na produção e/ou } \\
\text { processamento de alimentos }\end{array}$ & $2.89^{\mathrm{a}}$ & $2.73^{\mathrm{a}}$ \\
\hline
\end{tabular}




\subsection{Focus Group}

O perfil dos participantes dos Focus Groups está descrito na Tabela III.3.

Tabela III. 3 - Perfil dos participantes selecionados para compor os quatro grupos de discussão (Focus Group)

\begin{tabular}{|c|c|c|c|c|c|}
\hline Participante & Sexo & Profissão & Idade & Classe social & $\begin{array}{l}\text { Grupo de } \\
\text { Discussão }\end{array}$ \\
\hline Participante 1.1 & $\mathrm{~F}$ & Estudante & 23 & $\mathrm{~A}$ & 1 \\
\hline Participante 1.2 & $\mathrm{~F}$ & Estudante & 19 & B1 & 1 \\
\hline Participante 1.3 & M & Estudante & 19 & $\mathrm{~A}$ & 1 \\
\hline Participante 1.4 & $\mathrm{~F}$ & Estudante & 24 & $\mathrm{~A}$ & 1 \\
\hline Participante 1.5 & $\mathrm{~F}$ & Estudante & 28 & A & 1 \\
\hline Participante 1.6 & $\mathrm{~F}$ & Estudante & 24 & B1 & 1 \\
\hline Participante 1.7 & $\mathrm{~F}$ & Estudante & 29 & B1 & 1 \\
\hline Participante 1.8 & $\mathrm{~F}$ & Estudante & 31 & $\mathrm{~A}$ & 1 \\
\hline Participante 2.1 & $\mathrm{~F}$ & Estudante & 25 & $\mathrm{C} 1$ & 2 \\
\hline Participante 2.2 & $\mathrm{~F}$ & Estudante & 20 & B2 & 2 \\
\hline Participante 2.3 & $\mathrm{~F}$ & Estudante & 24 & $\mathrm{C} 1$ & 2 \\
\hline Participante 2.4 & $\mathrm{~F}$ & Estudante & 25 & B2 & 2 \\
\hline Participante 2.5 & $\mathrm{M}$ & Estudante & 25 & B1 & 2 \\
\hline Participante 2.6 & $\mathrm{M}$ & Estudante & 20 & B2 & 2 \\
\hline Participante 2.7 & $\mathrm{~F}$ & Estudante & 21 & B1 & 2 \\
\hline Participante 2.8 & $\mathrm{~F}$ & Estudante & 28 & B2 & 2 \\
\hline Participante 3.1 & $\mathrm{~F}$ & Funcionário Publico & 50 & $\mathrm{~A}$ & 3 \\
\hline Participante 3.2 & $\mathrm{~F}$ & Funcionário Publico & 32 & B2 & 3 \\
\hline Participante 3.3 & $\mathrm{~F}$ & Funcionário Publico & 34 & B2 & 3 \\
\hline Participante 3.4 & $\mathrm{~F}$ & Funcionário Publico & 38 & $\mathrm{~A}$ & 3 \\
\hline Participante 3.5 & $\mathrm{~F}$ & Funcionário Publico & 40 & B1 & 3 \\
\hline Participante 3.6 & M & Funcionário Publico & 37 & B1 & 3 \\
\hline Participante 3.7 & $\mathrm{~F}$ & Funcionário Publico & 28 & B2 & 3 \\
\hline Participante 3.8 & M & Funcionário Publico & 38 & B2 & 3 \\
\hline Participante 3.9 & $\mathrm{~F}$ & Funcionário Publico & 40 & B2 & 3 \\
\hline Participante 4.1 & $\mathrm{~F}$ & Militar & 34 & B2 & 4 \\
\hline Participante 4.2 & $\mathrm{~F}$ & Militar & 45 & $\mathrm{~A}$ & 4 \\
\hline Participante 4.3 & M & Militar & 33 & B1 & 4 \\
\hline Participante 4.4 & M & Militar & 34 & $\mathrm{C} 1$ & 4 \\
\hline Participante 4.5 & $\mathrm{~F}$ & Militar & 35 & B2 & 4 \\
\hline Participante 4.6 & $\mathrm{~F}$ & Militar & 42 & $\mathrm{~A}$ & 4 \\
\hline Participante 4.7 & M & Militar & 30 & B1 & 4 \\
\hline Participante 4.8 & $\mathrm{M}$ & Militar & 33 & $\mathrm{~B} 1$ & 4 \\
\hline
\end{tabular}


O grupo 1 foi composto por oito participantes, dos quais 7 eram mulheres e um homem. Os participantes tinham entre 19 e 30 anos e eram estudantes de graduação ou pósgraduação. Dos oito participantes do grupo 2, 6 eram mulheres e dois homens, com idades entre 20 e 28 anos. Eles eram todos estudantes. No grupo 3 havia 6 mulheres e 2 homens com idade entre 32 e 50 anos. Eles eram professores, secretários ou técnicos de laboratório. O grupo 4 foi composto por 4 homens e 4 mulheres com idade entre 30 e 45 anos. Eles eram todos militares. Nos grupos 3 e 4 todos os participantes tiveram pelo menos um filho. Os tópicos abordados serão discutidos a seguir:

\subsubsection{Apresentação e hábitos alimentares}

Durante a apresentação dos participantes e seus hábitos alimentares, a maioria afirmou seguir o que considera "hábitos não saudáveis": Consumo excessivo de alimentos com grande quantidade de gordura, açúcar ou calorias; consumo de alimentos fritos ou industrializados. Ter hábitos saudáveis na opinião dos participantes inclui se exercitar, consumir bastantes frutas e verduras, comer moderadamente e de maneira variada, evitando alimentos industrializados e preferindo aqueles feitos em casa. Seguindo uma linha diferente de pensamento, um dos participantes apontou que o simples fato de comer vegetais não garante uma alimentação saudável:

"Depende da qualidade da comida que você come. Vamos dar legumes e frutas como um exemplo. Nós não sabemos a origem desses alimentos, então se você está consumindo um alimento que é geneticamente modificado ou com muitos pesticidas, você pode estar comendo frutas e legumes, mas você não está sendo saudável".

\subsubsection{Produtos cárneos: saudáveis ou não saudáveis?}

Os grupos 1 e 2 definiram os produtos cárneos como produtos derivados da carne ou o que não era carne in natura. Os grupos 3 e 4 deram exemplos: salsichas, hambúrguer e 
nuggets foram citados. Por serem considerados fontes de proteína, o consumo moderado de produtos cárneos foi visto como um hábito saudável. No entanto, os grupos concordaram que a presença de gordura em excesso e aditivos resulta em produtos cárneos não saudáveis. $\mathrm{O}$ consumo excessivo de produtos cárneos foi visto como um hábito pouco saudável pelos grupos 1 e 2, e o grupo 3 considerou que alguns tipos de produtos são mais saudáveis do que outros, dependendo de sua composição. Para o grupo 4 os produtos cárneos não são saudáveis, pois segundo um dos participantes:

“A probabilidade de alguém ficar doente comendo um hambúrguer é maior do que a de alguém comendo alface".

\subsubsection{O que pode ser feito para tornar os produtos cárneos mais saudáveis?}

Quando questionados sobre o que pode ser feito para tornar os produtos cárneos mais saudáveis, três dos quatro grupos responderam que a quantidade de aditivos (nitritos, conservantes) deve ser reduzida. Os participantes indicaram que conservantes naturais devem ser utilizados. Redução da quantidade de gordura também foi apontada.

"Eu acho que o que torna o produto cárneo menos saudável é a incorporação de aditivos: nitrato de sódio, antioxidantes. Acho que a substituição por aditivos naturais os tornaria, no mínimo, um pouco mais saudáveis".

3.1.4. O que é irradiação de alimentos? Qual seria o propósito da irradiação de alimentos?

Os grupos 1 e 2 demonstraram mais conhecimento sobre essa tecnologia do que os grupos 3 e 4 . Talvez seja porque os grupos 1 e 2 foram formados por estudantes de graduação ou pós-graduação, que podem ter visto algo sobre essa tecnologia em alguma disciplina universitária. No grupo 3, apenas dois participantes tiveram alguma ideia sobre a irradiação. 
No grupo 4 esta tecnologia era desconhecida para todos no grupo. A definição dada por um dos participantes do grupo 1 foi:

"A radiação é a aplicação de um feixe de raios que não são prejudiciais em uma determinada quantidade".

Em relação ao objetivo desta tecnologia, a maioria dos grupos a relacionaram à conservação de alimentos:

"Ele ataca o microrganismo decompondo proteínas ou DNA" - Grupo 1

"Tem ação bactericida" - Grupo 2

"É uma tecnologia usada para esterilizar alimentos" - Grupo 3

3.1.5. Quais aspectos o impediriam ou o encorajariam a consumir alimentos irradiados?

Todos os grupos se mostraram um pouco preocupados com o consumo de alimentos irradiados. Essa preocupação foi mais pronunciada nos grupos 3 e 4. A maioria dos participantes indicou que a falta de conhecimento sobre essa tecnologia é o que dificulta sua aceitação. Os grupos 1 e 2 indicaram que consumiriam porque tinham alguma ideia do processo, mas seus pais provavelmente relutariam em aceitar esse tipo de alimento. Algumas das afirmações dos grupos 1 e 2 foram:

"Acho que a gente consome porque a gente sabe o que é, a gente tem uma ideia, mas a população em geral não tem".

"Com o conhecimento que tenho eu compraria, mas minha mãe perguntaria: 'mas podemos comer?"”.

O Grupo 3 dividiu opiniões sobre a aceitação de alimentos irradiados. Alguns participantes afirmaram que só comprariam e dariam aos filhos se já estivessem muito bem 
informados sobre essa tecnologia. Um participante indicou que, se o produto estava no mercado, provavelmente foi aprovado por algum regulamento e, portanto, caberia ao consumidor optar por consumi-lo ou não. Outro participante afirmou que a palavra "radiação" refere-se a algo radioativo e o verbo "irradiar" refere-se a colocar radiação no produto, o que não é visto como algo seguro.

"Eu acho que quando as pessoas ouvem que um determinado alimento é irradiado, elas se assustam; Acho que as vendas de alimentos irradiados cairiam se as pessoas lessem os rótulos ou conhecessem melhor o símbolo".

"Eu ficaria com medo de dar esse tipo de alimento para meus filhos"

O grupo 4 foi o mais relutante em aceitar alimentos irradiados:

"Eu não compraria esse tipo de alimento"

"Eu ficaria com medo".

3.1.6.Você costuma ler o rótulo dos alimentos que consome? Qual símbolo identifica um alimento irradiado? O radura é um símbolo que representa bem um alimento irradiado?

A maioria dos participantes que lêem os rótulos o fazem procurando informações específicas, como quantidade de calorias, gordura e sal. Alguns dos participantes não lêem os rótulos. No grupo 4, apenas um participante tinha esse hábito porque sua filha é alérgica a alguns componentes de alguns alimentos.

O símbolo radura era conhecido apenas por um participante do grupo 1. Um participante do grupo 2 declarou que ele pode ter visto, mas não sabia o que significava.

Todos os grupos concordaram que o símbolo não identifica bem alimentos irradiados. 
"Não representa bem o alimento irradiado, mas acho que se você usar um símbolo assustador, ele transmitirá uma ideia de perigo" - Grupo 1

"Eu posso ter visto o símbolo, mas não sabia o que era" - Grupo 2.

Em geral, os grupos 3 e 4, que eram compostos por pessoas com mais de 30 anos e que tinham filhos, mostraram-se mais relutantes em aceitar alimentos irradiados. Isso corrobora a ideia de que os jovens estão mais abertos a aceitar novas tecnologias (Grupos 1 e 2). Jovens e adultos estão expostos ao mesmo fluxo de novidades apresentadas pelo mundo globalizado. No entanto, os jovens parecem aceitar esses avanços mais naturalmente. Da mesma forma, em relação ao uso da nanotecnologia, Rollin, Kennedy e Wills (2011) relataram que pessoas mais velhas parecem ser menos favoráveis do que os mais jovens. Ainda assim, os participantes dos Grupos 1 e 2 deixaram claro que só comprariam alimentos irradiados porque haviam ouvido falar da tecnologia e acreditavam que era segura.

O Grupo 3, formado por pessoas da Faculdade de Zootecnia e Engenharia de Alimentos - FZEA / USP (assim como os Grupos 1 e 2) teve um pouco mais de abertura do que o Grupo 4, formado por pessoas de fora da Universidade. Isso demonstra que o nível de conhecimento sobre tecnologia realmente afeta a percepção do consumidor.

De fato, fornecer informações aos consumidores é uma maneira de ganhar sua confiança. Em um estudo de grupo focal conduzido por Deliza, Rosenthal e Silva (2003), sobre conscientização e atitudes dos consumidores em relação a alimentos processados e bebidas, três dos quatro grupos de consumidores consideraram que o produto tinha melhor qualidade quando a informação sobre a tecnologia foi apresentada. O estudo de Van Wezemael et al (2012), que investigou se as preferências dos consumidores por carne bovina podem ser modificadas ao fornecer informações sobre as tecnologias de processamento aplicadas, também mostrou que informações detalhadas aumentaram a aceitação pelo consumidor das tecnologias aplicadas à carne. Além disso, a experiência de consumo 
(experiência sensorial) foi mais importante que a informação fornecida. Entretanto, de acordo com os autores, embora o fornecimento de informações sobre uma tecnologia seja frequentemente visto como uma forma de reduzir a rejeição do consumidor, a quantidade de informação e a forma pela qual ela é passada influenciam muito a formação de opinião. Isso ocorre porque o conhecimento da tecnologia pode ter um efeito psicológico na percepção do produto (SIEGRIST, 2008). Isso foi claramente percebido no Grupo 3, quando, mesmo depois de alguns participantes, que disseram conhecer o processo de irradiação, terem explicado o que entenderam, os outros continuaram cautelosos em aceitar a tecnologia. Outros fatores que afetam a aceitação de uma tecnologia pelos consumidores são: confiança do consumidor na fonte de informação, falta de benefícios percebidos, percepção pública de que alguma incerteza está sendo "escondida" pelas instituições reguladoras ou mesmo a ideia de que as consequências do uso do produto/tecnologia são largamente desconhecidos pela comunidade científicos (ROLLIN; KENNEDY; WILLS, 2011). O conhecimento sobre o produto ou tecnologia influencia a atitude dos indivíduos em um processo conhecido como bottom-up. $\mathrm{O}$ conhecimento gera crenças que podem ser positivas ou negativas, a média ponderada entre essas crenças resulta na aceitação ou rejeição do objeto (NIELSEN et al., 2009).

O medo do nome da tecnologia, como explicado por um dos participantes ("A palavra 'radiação' se assemelha a uma coisa radioativa, o que não é bom") também foi relatado por Nielsen et al. (2009), quando estudaram a percepção do consumidor (em um Focus Group) sobre o uso de processamento de alta pressão e campo elétrico pulsante na produção de alimentos. Segundo os autores, o ceticismo em relação a esta tecnologia deve-se ao fato de o nome gerar um medo da eletricidade. Algumas frases ditas pelos grupos foram: "Eu simplesmente não consigo imaginar essa alta voltagem. Estou com medo. Soa mal. A eletricidade não é para mim". 
Embora a informação / conhecimento sobre a tecnologia fosse considerada pelos grupos como um fator importante de aceitação, a maioria dos participantes afirmou não ler os rótulos dos alimentos que compram / consomem. Segundo Rollin, Kennedy e Wills (2011), mesmo que a rotulagem seja exigida pelos consumidores, poucos deles realmente lêem os rótulos quando compram alimentos. Além disso, com a variedade de rotulagem de produtos alimentícios, não se sabe como os consumidores irão interpretá-los e como eles irão correlacionar as informações no rótulo. Quando alegações são escritas nos rótulos, a confiança é essencial para a aceitação de alimentos, porque os consumidores devem acreditar nas alegações de saúde fornecidas pelos produtores (SIEGRIST, 2008).

\subsection{Check-all-that-apply (CATA)}

Os atributos selecionados para compor a lista final estão dispostos na Tabela III.4. Os termos foram apresentados de forma aleatorizada entre os consumidores, a fim de reduzir o efeito da posição na avaliação dos atributos. A Figura III.2 ilustra a distribuição gráfica das salsichas em relação aos atributos levantados.

Salsichas com teor reduzido de sódio ocuparam uma posição claramente distante da amostra controle, sem redução de sódio (F2). As salsichas F2 foram descritas como salgadas, duras, emborrachadas, com dureza externa, cor intensa e avermelhada. Salsichas com teor reduzido de sódio permaneceram próximas umas das outras. No entanto, é possível detectar alguma separação entre as salsichas que receberam a maior dose de radiação (I3.0 e I4.5 kGy) das salsichas que receberam 1,5 kGy ou não foram irradiadas (F0). Os tratamentos I3.0 e I4.5 foram caracterizadas como cor homogênea, sabor de defumado, sabor intenso, textura macia e aroma característico. As salsichas F0 foram percebidas como gordurosas, com aroma suave e sal ideal. I1.5 foi caracterizada como tendo aroma de defumado e sabor de condimento. 
Tabela III. 4 - Atributos selecionados para compor a lista do teste CATA aplicado a salsichas com redução de sódio e irradiadas

\begin{tabular}{|c|c|c|c|}
\hline Aparência & Aroma & Sabor & Textura \\
\hline Cor agradável & Aroma estranho & Sal ideal & Dureza externa \\
\hline Cor escura & Aroma de defumado & Pouco sal & Dura \\
\hline Cor clara & Aroma intenso & Salgada & Borrachuda \\
\hline Avermelhada & Aroma suave & Sabor intenso & Macia \\
\hline Cor característica & Aroma característico & Sabor de ranço & Suculenta \\
\hline Cor intensa & Odor de ranço & $\begin{array}{l}\text { Sabor } \\
\text { condimento }\end{array}$ & Pouco suculenta \\
\hline Com brilho & Aroma de condimento & Sabor de pimenta & Textura granulosa \\
\hline Cor homogênea & Aroma de pimenta & Sabor de defumado & Gordurosa \\
\hline
\end{tabular}

A principal diferença entre salsichas foi observada entre formulações com e sem redução de sódio. O processo de irradiação causou impactos mínimos percebidos pelos consumidores. Os atributos distribuídos para F2 foram mais relacionados à textura e cor (cor escura, cor intensa, emborrachada, dureza externa, dura), enquanto os atributos para as demais amostras descreveram aroma e sabor (sabor leve, sabor defumado, aroma defumado, aroma intenso, aroma de condimentos, aroma característico). Estes resultados indicam que a redução de sódio teve um impacto mais forte nas características da textura, enquanto que a irradiação um impacto (ainda que pequeno) no sabor dos produtos. A redução da concentração de sódio pode ter impactado a extração de proteínas durante a etapa de cominuição para a preparação das salsichas. Isso pode ter prejudicado a formação da rede de proteínas, levando a problemas na textura dos produtos. A irradiação de produtos cárneos pode causar oxidação de lipídios, levando à formação de sabor e odor de ranço. Entretanto, nenhum desses dois atributos foi relacionado a salsichas irradiadas, ou seja, os consumidores não perceberam esses atributos com intensidade nas amostras. As palavras listadas no CATA para essas amostras foram 
características típicas de salsichas (DE AZEVEDO et al., 2006; HORITA et al., 2017), e foram as mesmas usadas para descrever F0. 
Figura III. 2- Distribuição gráfica das salsichas com redução de em sódio e irradiadas em relação aos atributos sensoriais percebidos pelos consumidores no teste CATA

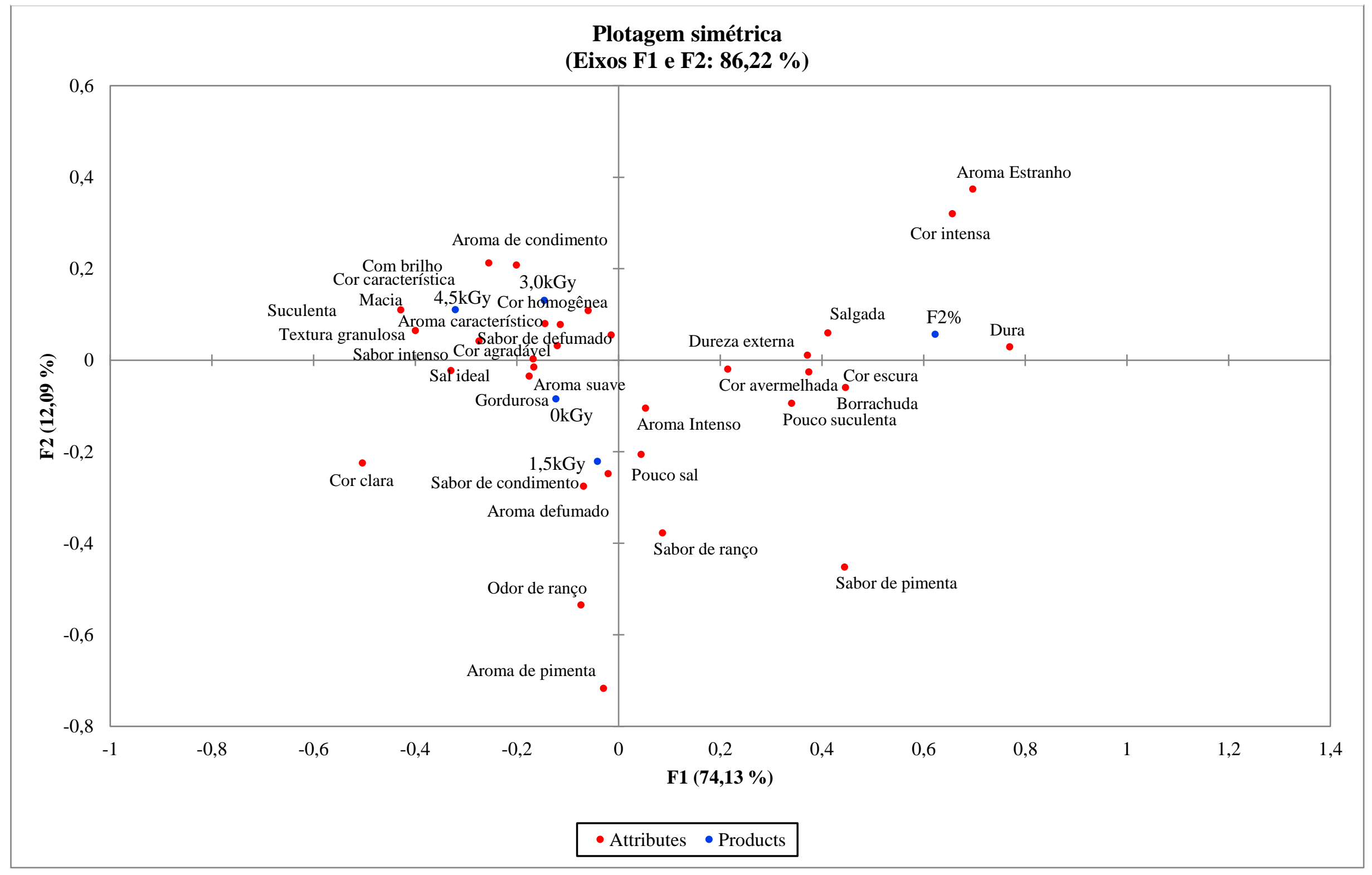




\section{CONCLUSÃO}

Observou-se neste estudo que a irradiação de alimentos ainda desperta grande receio nos consumidores. Embora os jovens estejam mais abertos a receber novas tecnologias, no caso de produtos irradiados, o nível de conhecimento fez a diferença na aceitação. A forma como as informações foram apresentadas contribuiu muito para a formação de opinião. Foi visto neste estudo que simplesmente apresentar as informações em texto não alterou a pontuação total da escala FTNS desses consumidores em comparação com os consumidores que não receberam as informações. No entanto, nos Focus Groups formados por alunos que tiveram algum contato prévio com essa tecnologia durante seus estudos percebeu-se melhor aceitação do que em grupos que não tiveram esse contato. Isso demonstra que, para que a irradiação de alimentos seja aceita, o entendimento dessa tecnologia precisa ser profundamente trabalhado com os consumidores. Em relação aos atributos sensoriais, a aplicação de radiação não trouxe grandes alterações quando comparada à redução de sódio. 


\section{REFERENCIAS}

ARES, Gastón; JAEGER, Sara R. Check-all-that-apply questions: Influence of attribute order on sensory product characterization. Food Quality and Preference, v. 28, n. 1, p. 141-153, 2013.

AASLYNG, Margit Dall; VESTERGAARD, Christian; KOCH, Anette Granly. The effect of salt reduction on sensory quality and microbial growth in hotdog sausages, bacon, ham and salami. Meat Science, v. 96, n. 1, p. 47-55, 2014.

BARRENA, Ramo; SÁNCHEZ, Mercedes. Neophobia, personal consumer values and novel food acceptance. Food quality and preference, v. 27, n. 1, p. 72-84, 2013.

CAREY, M. A. Focus groups. International Encyclopedia of the Social \& Behavioral Sciences, 274-279, 2015.

COX, D. N.; EVANS, G. Construction and validation of a psychometric scale to measure consumers' fears of novel food technologies: The food technology neophobia scale. Food quality and preference, v. 19, n. 8, p. 704-710, 2008.

DE ANDRADE, Juliana Cunha et al. Consumer sensory and hedonic perception of sheep meat coppa under blind and informed conditions. Meat science, v. 137, p. 201-210, 2018. DE BARCELLOS, Marcia D. et al. European consumers' acceptance of beef processing technologies: A focus group study. Innovative Food Science \& Emerging Technologies, v. 11, n. 4, p. 721-732, 2010.

DELIZA, R.; ROSENTHAL, A.; SILVA, A. L. S. Consumer attitude towards information on non conventional technology. Trends in food science \& technology, v. 14, n. 1-2, p. 43-49, 2003.

DOOLEY, Lauren; LEE, Young-seung; MEULLENET, Jean-François. The application of check-all-that-apply (CATA) consumer profiling to preference mapping of vanilla ice cream and its comparison to classical external preference mapping. Food quality and preference, v. 21, n. 4, p. 394-401, 2010.

DOS SANTOS, Bibiana Alves et al. Monosodium glutamate, disodium inosinate, disodium guanylate, lysine and taurine improve the sensory quality of fermented cooked sausages with 50\% and 75\% replacement of $\mathrm{NaCl}$ with KCl. Meat Science, v. 96, n. 1, p. 509-513, 2014.

DOS SANTOS, B. A. et al. Check all that apply and free listing to describe the sensory characteristics of low sodium dry fermented sausages: Comparison with trained panel. Food Research International, v. 76, p. 725-734, 2015. 
EHLERMANN, Dieter AE. Particular applications of food irradiation: Meat, fish and others. Radiation Physics and Chemistry, v. 129, p. 53-57, 2016.

Eurobarometer. Social values, science and technology. Special Eurobarometer 225/Wave 63.1. Brussels: TNS Opinion \& Social. June 2005.

EVANS, G. et al. Reliability and predictive validity of the Food Technology Neophobia Scale. Appetite, v. 54, n. 2, p. 390-393, 2010.

FREWER, L.; DE JONGE, J.; VAN KLEEF, E. Consumer perceptions of food safety. Medical Sciences-Volume II, 243. 2009.

HORITA, C. N. et al. Sensory profiling of low sodium frankfurter containing garlic products: Adequacy of Polarized Projective Mapping compared with trained panel. Meat science, v. 131, p. 90-98, 2017.

KANATT, Sweetie R.; CHANDER, Ramesh; SHARMA, Arun. Effect of radiation processing on the quality of chilled meat products. Meat science, v. 69, n. 2, p. 269-275, 2005.

LILIC, Slobodan et al. Reducing sodium chloride content in meat burgers by adding potassium chloride and onion. Procedia Food Science, v. 5, p. 164-167, 2015.

LOBO, F. et al. Underlying chemical mechanisms of the contradictory effects of $\mathrm{NaCl}$ reduction on the redox-state of meat proteins in fermented sausages. LWT-Food Science and Technology, v. 69, p. 110-116, 2016.

MADERA-SANTANA, Tomás J. et al. Effect of gamma irradiation on physicochemical properties of commercial poly (lactic acid) clamshell for food packaging. Radiation Physics and Chemistry, v. 123, p. 6-13, 2016.

MATIN, Anahita Hosseini et al. Do environmental attitudes and food technology neophobia affect perceptions of the benefits of nanotechnology?. International Journal of Consumer Studies, v. 36, n. 2, p. 149-157, 2012.

MCGOUGH, Megan M. et al. Reducing sodium levels in frankfurters using a natural flavor enhancer. Meat science, v. 91, n. 2, p. 185-194, 2012.

MOSTAFAVI, Hossein Ahari; MIRMAJLESSI, Seyed Mahyar; FATHOLLAHI, Hadi. The potential of food irradiation: benefits and limitations. In: Trends in vital Food and control engineering. IntechOpen, 2012. 
NIELSEN, Henriette Boel et al. Consumer perception of the use of high-pressure processing and pulsed electric field technologies in food production. Appetite, v. 52, n. 1, p. 115-126, 2009.

OLSEN, Nina Veflen; GRUNERT, Klaus G.; SONNE, Anne-Mette. Consumer acceptance of high-pressure processing and pulsed-electric field: a review. Trends in Food Science \& Technology, v. 21, n. 9, p. 464-472, 2010.

PARK, J. G. et al. Effects of gamma irradiation and electron beam irradiation on quality, sensory, and bacterial populations in beef sausage patties. Meat science, v. 85, n. 2, p. 368$372,2010$.

PERREA, Toula; GRUNERT, Klaus G.; KRYSTALlIS, Athanasios. Consumer value perceptions of food products from emerging processing technologies: A cross-cultural exploration. Food Quality and Preference, v. 39, p. 95-108, 2015.

ROLLIN, Fanny; KENNEDY, Jean; WILLS, Josephine. Consumers and new food technologies. Trends in food science \& technology, v. 22, n. 2-3, p. 99-111, 2011.

SCHNETTLER, Berta et al. Food neophobia, nanotechnology and satisfaction with life. Appetite, v. 69, p. 71-79, 2013.

SIEGRIST, Michael. Factors influencing public acceptance of innovative food technologies and products. Trends in Food Science \& Technology, v. 19, n. 11, p. 603-608, 2008.

TROY, Declan J. et al. Sustainable and consumer-friendly emerging technologies for application within the meat industry: An overview. Meat science, v. 120, p. 2-9, 2016.

VAN WEZEMAEL, Lynn et al. The effect of technology information on consumer expectations and liking of beef. Meat science, v. 90, n. 2, p. 444-450, 2012.

VARELA, Paula; ARES, Gastón. Sensory profiling, the blurred line between sensory and consumer science. A review of novel methods for product characterization. Food Research International, v. 48, n. 2, p. 893-908, 2012.

VERNEAU, Fabio et al. Consumer fears and familiarity of processed food. The value of information provided by the FTNS. Appetite, v. 73, p. 140-146, 2014.

VIDIGAL, Márcia CTR et al. Food technology neophobia and consumer attitudes toward foods produced by new and conventional technologies: A case study in Brazil. LWT-Food Science and Technology, v. 60, n. 2, p. 832-840, 2015. 


\section{CONCLUSÃO GERAL}

Os resultados demonstraram embora a redução de 2 para $1.25 \%$ de $\mathrm{NaCl}$ nas formulações de salsicha tenha provocado algumas alterações físicas, químicas e estruturais estes produtos (que alcançaram redução de $27,18 \%$ de sódio) foram aceitas sensorialmente. Assim, a primeira conclusão é que é possível produzir salsicha com $1,25 \%$ de $\mathrm{NaCl}$ obtendo um produto mais saudável e ainda bem aceito.

No que diz respeito à segurança microbiológica de um produto reduzido em sal, a irradiação mostrou-se um método eficaz no controle de microrganismos. Concluiu-se que, devido á sua grande eficácia, a menor dose testada (1,5 kGy) é a mais indicada para utilização, visto que esta dose, além de controlar o desenvolvimento das bactérias provoca menores efeitos nos atributos de qualidade do produto.

Os estudos com consumidores demostram grandes receios da população tanto quanto à saudabilidade de produtos cárneos quanto ao uso de radiação. A fim de melhorar a percepção dos consumidores sobre alimentos irradiados deve-se realizar um trabalho amplo, em longo prazo, de conscientização e informação sobre o uso, função e consequências desta tecnologia no alimento. 


\section{Anexo 1}

\begin{tabular}{|c|c|}
\hline Declarações - Português & Statements - English \\
\hline $\begin{array}{l}\text { 1- Eu não estou totalmente familiarizado com tecnologias não convencionais } \\
\text { empregadas na produção e/ou processamento de alimentos. }\end{array}$ & New food technologies are something I am uncertain about. \\
\hline 2- Novos alimentos não são mais saudáveis do que os alimentos tradicionais. & New foods are not healthier than traditional foods. \\
\hline $\begin{array}{l}\text { 3- As afirmações sobre os benefícios de tecnologias não convencionais empregadas na } \\
\text { produção e/ou processamento de alimentos são frequentemente muito exageradas. }\end{array}$ & The benefits of new food technologies are often grossly overstated. \\
\hline $\begin{array}{l}\text { 4- Já existem inúmeros alimentos saborosos no mercado, então nós não precisamos de } \\
\text { tecnologias não convencionais para produzir mais alimentos. }\end{array}$ & $\begin{array}{l}\text { There are plenty of tasty foods around so we do not need to use new food } \\
\text { technologies to produce more }\end{array}$ \\
\hline $\begin{array}{l}\text { 5- Tecnologias não convencionais empregadas na produção e/ou processamento de } \\
\text { alimentos reduzem a qualidade natural dos alimentos. }\end{array}$ & New food technologies decrease the natural quality of food. \\
\hline $\begin{array}{l}\text { 6- Tecnologias não convencionais empregadas na produção e/ou processamento de } \\
\text { alimentos provavelmente não trarão, em longo prazo, efeitos negativos à saúde. }\end{array}$ & $\begin{array}{l}\text { New food technologies are unlikely to have long term negative health } \\
\text { effects }\end{array}$ \\
\hline $\begin{array}{l}\text { 7- Tecnologias não convencionais empregadas na produção e/ou processamento de } \\
\text { alimentos proporcionam às pessoas um maior controle sobre as suas escolhas } \\
\text { alimentares. }\end{array}$ & New food technologies give people more control over their food choices \\
\hline $\begin{array}{l}\text { 8- Novos produtos que utilizam tecnologias não convencionais podem ajudar as pessoas } \\
\text { a terem uma dieta equilibrada. }\end{array}$ & $\begin{array}{l}\text { New products using new food technologies can help people have a } \\
\text { balanced diet }\end{array}$ \\
\hline $\begin{array}{l}\text { 9- Tecnologias não convencionais empregadas na produção e/ou processamento de } \\
\text { alimentos podem causar, em longo prazo, efeitos negativos ao meio ambiente. }\end{array}$ & $\begin{array}{l}\text { New food technologies may have long term negative environmental } \\
\text { effects }\end{array}$ \\
\hline $\begin{array}{l}\text { 10- Pode ser arriscado mudar rapidamente para tecnologias não convencionais } \\
\text { empregadas na produção e/ou processamento de alimentos. }\end{array}$ & It can be risky to switch to new food technologies too quickly. \\
\hline $\begin{array}{l}\text { 11- A sociedade não deve depender demais de tecnologias para resolver os seus } \\
\text { problemas alimentares. }\end{array}$ & $\begin{array}{l}\text { Society should not depend heavily on technologies to solve its food } \\
\text { problems }\end{array}$ \\
\hline $\begin{array}{l}\text { 12- Não faz sentido experimentar alimentos produzidos a partir de alta tecnologia, } \\
\text { porque os que eu consumo já são bons o suficiente. }\end{array}$ & $\begin{array}{l}\text { There is no sense trying out high-tech food products because the ones I eat } \\
\text { are already good enough. }\end{array}$ \\
\hline $\begin{array}{l}\text { 13- A mídia geralmente fornece uma visão equilibrada e imparcial das tecnologias não } \\
\text { convencionais empregadas na produção e/ou processamento de alimentos }\end{array}$ & $\begin{array}{l}\text { The media usually provides a balanced and unbiased view of new food } \\
\text { technologies }\end{array}$ \\
\hline
\end{tabular}




\section{Anexo 2 - Informação sobre o processo de irradiação fornecida aos consumidores} no teste FTNS

A irradiação de alimentos consiste na exposição do alimento a uma fonte de radiação ionizante (feixes de elétrons, $\underline{\text { raios-X }}$, ou raios-gama). Essa técnica visa matar bactérias causadoras de intoxicação alimentar ou que degradam o alimento, além de retardar a

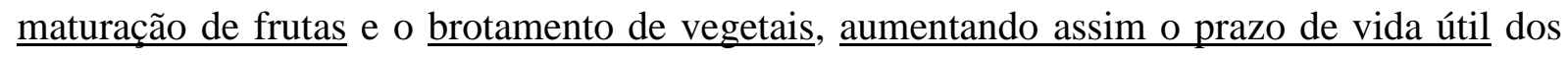
alimentos. O processo de irradiação é conhecido como pasteurização a frio, pois com ele são obtidos resultados semelhantes à pasteurização à base de calor, mas sem o calor. A irradiação em certas doses é capaz de eliminar todos os contaminantes vivos, criando alimentos estéreis. Esses alimentos são necessários para pessoas com imunidade comprometida, como por exemplo, pacientes que sofrem de AIDS ou câncer. A irradiação de alimentos já é utilizada em mais de 60 tipos de alimentos em mais de 40 países em todo o mundo. 